\title{
Molecular Changes in the Postmortem Parkinsonian Brain
}

Damien Toulorge ${ }^{1}$, Anthony H.V. Schapira ${ }^{2}$ and Rodolphe Hajj ${ }^{3^{*}}$

${ }^{1}$ Encefa, 123 Avenue de Fontainebleau, 94270 Le Kremlin Bicêtre

${ }^{2}$ Department of Clinical Neuroscience, UCL Institute of Neurology, London, UK

${ }^{3}$ Pharnext, 11 rue des Peupliers, 92130 Issy-Les-Moulineaux, France.

* Correspondence should be addressed to R.H. (rhajj@ pharnext.com)

Running title: Postmortem changes in Parkinsonian brain

Key words: Parkinson's, postmortem brain, molecular changes 


\begin{abstract}
Despite considerable research efforts, the cellular and molecular mechanisms involved in the initiation and progression of Parkinson's disease (PD) are still unknown. As a consequence, no treatment that slows down or stops the progression of the disease is currently available. In an effort better to understand the molecular pathogenesis of this disease, we review here the biochemical changes that have been documented through the observation and the analysis of postmortem PD brains.
\end{abstract}




\section{Introduction}

Parkinson disease (PD) is a progressive neurodegenerative illness of the human nervous system afflicting more than $1 \%$ of people over the age of 65 and more than $4 \%$ of the population by the age of 85 (de Rijk et al. 2000). The diagnosis of PD depends upon the presence of motor deficits that in turn are predominantly the consequence of loss of dopaminergic neurons of the substantia nigra $(\mathrm{SN})$. Non-motor symptoms may develop prior to motor deficits, but more frequently appear in the more advanced stages and are due to loss of both dopaminergic and non-dopaminergic neuronal pathways (Chaudhuri et al. 2006).

Despite significant research efforts undertaken to understand PD, available treatments are only symptomatic and do not affect the progression of the disease. Several reasons have been proposed to explain this failure, in particular the fact that research for effective treatments is hampered by lack of knowledge on the pathogenetic processes explaining this disease(Stanzione and Tropepi 2011). Indeed, while existing cellular and animal models are important for our understanding of the apparent pathogenesis of $\mathrm{PD}$, paradigms that reflect the progressive nature of the illness and its complexity in terms of the extent of pathology and underlying biochemical changes are also lacking. Consequently, the progress in the development of approaches that stop or slow the disease progression is very low(Duty and Jenner 2011).

PD is a pathology affecting only humans. For this reason we believe that the study of the human brain is a prerequisite for understanding this disorder. Here we review the molecular changes observed through the analysis of the human postmortem PD brains. We will address here the changes in protein expression, excluding RNA expression data (reviewed elsewhere(Cooper-Knock et al. 2012)) and discuss changes in PD brain only. 


\section{Neurotransmitters and neurotrophic factors}

Neurotransmitters, receptors and transporters

Cell loss is observed in PD in several brain areas. While dopaminergic cell loss is believed to be responsible for the motor alterations in the disease, glutamatergic, cholinergic, tryptaminergic, GABAergic, noradrenergic and adrenergic neurons are also affected during the progression of the pathology(Braak and Braak 2000) (Table 1). Levels of tyrosine hydroxylase $(\mathrm{TH})$, the rate limiting enzyme in dopamine synthesis, dopamine transporters (DAT) and vesicular monoamine transporter 2(Thibaut et al. 1995) (VMAT2) are severely reduced in the SN of PD patients(Kastner et al. 1993). In dopaminergic neurons, increased levels of neuromelanin were reported, suggesting increased oxidation of dopamine(Halliday et al. 2005). Accordingly, the content of the oxidized metabolites of dopamine, notably 5-SCysteinyl-Dopamine, 5-S-Cysteinyl-DOPA and 5-S-Cysteinyl-DOPAC(Spencer et al. 1998) as well as NADH quinone oxidoreductase(van Muiswinkel et al. 2004) (NQO1), an enzyme that detoxifies dopamine quinone, are also increased.

The loss of dopaminergic neurons projecting fibers in the striatum induces a strong decrease in TH, DAT and VMAT2 levels in the caudate nucleus and the putamen(Wills et al. 2010; Miller et al. 1999; Ryoo et al. 1998; Güzey et al. 2012); while dopamine levels and its catabolites DOPAC and HVA are severely impaired in caudate nucleus, putamen and nucleus accumbens(Gerlach et al. 1996). Nevertheless, dopamine receptor 1(Mattila et al. 2001; Piggott et al. 1999; Griffiths et al. 1994) (D1R) and dopamine receptor 3(Piggott et al. 1999) (D3R) densities are not affected by the loss of dopaminergic fibers, while its effect on dopamine receptor 2 (D2R) is unclear(Varani et al. 2010; Ahlskog et al. 1991; Piggott et al. 1999; Griffiths et al. 1994).

The progression of the pathology also severely impacts the cholinergic system. Indeed, choline acetyltransferase, which catalyzes acetylcholine (Ach) production, is reduced in 
several brain areas including the hippocampus, thalamus, sub-thalamic nuclei and frontal cortex(Rinne et al. 1989; Xuereb et al. 1990; Gotti et al. 2006; Mattila et al. 2001) with simultaneous reduction of the activity of acetylcholine esterase(Xuereb et al. 1990). The distribution and content of Ach receptors (AchR) is also changed. Global density of AchR is increased in the globus pallidus(Griffiths et al. 1990) and decreased in the striatum(Gotti et al. 2006) where nicotinic AchR density(Court et al. 2000), more particularly $\alpha 4-, \alpha 6-, \beta 2-$ and $\beta 3$-subunits(Gotti et al. 2006), is also reduced. Decreased levels of $\alpha 4$ - and $\alpha 7$-subunits were also observed in cortical regions(Burghaus et al. 2003; Banerjee et al. 2000). For the muscarinic receptors, contradictory results were observed in the putamen(Griffiths et al. 1994; Ahlskog et al. 1991) while increased density of M2 muscarinic receptor was reported in cortical structures(Rinne et al. 1989).

The GABAergic system is affected in PD with increased and decreased levels reported in the striatum and the thalamus, respectively(Gerlach et al. 1996). GABA receptor density is also decreased in the $\mathrm{SN}$ of $\mathrm{PD}$ patients(Lloyd et al. 1977), and GABA A receptor $\left(\mathrm{GABA}_{\mathrm{A}} \mathrm{R}\right)$ reduced in the striatum(Griffiths et al. 1990). This occurs in parallel with changes in glutamatergic system. Whereas glutamate levels are not modified in several brain structures implicated in the pathology, levels of the glutamate metabolite glutamine are significantly elevated in the thalamus, the globus pallidus and the caudate nucleus(Gerlach et al. 1996). Interestingly, density of NMDA receptor(Gerlach et al. 1996) and levels of metabotropic glutamate receptor 5 (mGluR5) and its downstream regulator $\beta$-arrestin(Price et al. 2010) were decreased in the caudate nucleus. Finally, several other systems are also dysregulated in PD since abnormal levels and/or densities of adenosine 2A(Villar-Menéndez et al. 2014; Varani et al. 2010), angiotensin II(Allen et al. 1992), glycine(de Montis et al. 1982),

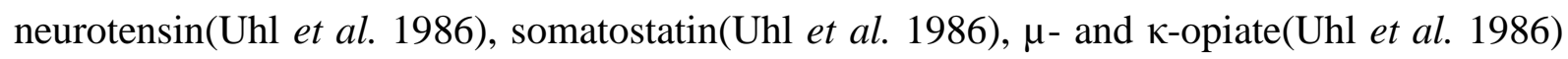
receptors have been reported. 


\section{Neurotrophic factors}

Neurotrophic factors are important in the maintenance of neuronal cell survival. Several studies demonstrated dysregulation of these factors in PD (Table 1). Glial cell-derived neurotrophic factor (GDNF) levels, the prototypical neurotrophic factor for dopaminergic neurons, are decreased in the SN of PD patients(Mogi et al. 2001; Chauhan et al. 2001), as well as one of its receptor, Ret(Decressac et al. 2012). Brain-derived neurotrophic factor (BDNF), another neurotrophic factor essential for neuronal cell survival, is underexpressed(Mogi et al. 1999; Imamura et al. 2005; Parain et al. 1999; Chauhan et al. 2001). Epidermal growth factor (EGF) and its receptors levels are also modified(Mogi et al. 1994a; Iwakura et al. 2005; Depboylu et al. 2012). Transforming growth factor $\alpha$ $(\mathrm{TGF} \alpha)($ Mogi et al. 1995) and $\beta 1$ (TGF $\beta 1)($ Mogi et al. 1995) levels are increased in PD brains, while nerve growth factor (NGF)(Mogi et al. 1999), ciliary neurotrophic factor (CNTF)(Chauhan et al. 2001) and basic fibroblast growth factor (bFGF)(Tooyama et al. 1994) are decreased. Neurotrophin-3, -4(Knott et al. 2002; Chauhan et al. 2001), heparinbinding EGF-like growth factor (HB-EGF)(Iwakura et al. 2005), and corticotropin releasing hormone (CRH)(Hoogendijk et al. 1998) expression is not affected in the pathology.

\section{Lewy bodies and PD linked genes}

\section{Lewy bodies}

Another hallmark of PD is the presence of intracytoplasmic fibrillar aggregates possessing a dense core and a peripheral halo forming Lewy bodies. Since excellent reviews detailing their composition were published(Wakabayashi et al. 2013), this issue will not be discussed in details in this review. 
Postmortem studies have demonstrated that Lewy pathology progressively and gradually involves greater parts of Parkisonian brain. This progressive characteristic had been used to classify the pathology in several stages. The first lesions appears in stage 1 in the olfactory bulb and the dorsal nucleus of the vagal nerve. In stage 2, lesions progress toward the locus coeruleus and the caudal raphe nuclei. The lesions then continue their ascending path to reach the amygdala, the pedulopontine nuclei and the pars compacta of the substantia nigra. At stage 4, 5 and 6, the lesion continues its progression upward and reaches the mesocortical and cortical areas (for more details, see (Braak et al. 2003)).

This apparent ascending progression of the disease, combined with the observation that embryonic neuronal grafts transplanted into PD patients also contained Lewy pathology(Li et al. 2008), gave rise to the prion-like hypothesis, which states that PD pathology can be propagated to neighbouring cells. $\alpha$-synuclein, one of the main constituent of Lewy bodies(Wakabayashi et al. 2013), represents one candidate that could eventually spread the pathology since it has the potency to be released from and uptaken by neurons(Steiner et al. 2011; Chauhan and Jeans 2015). This phenomenon is of particular interest since $\alpha$-synuclein has been found mutated in some familial forms of $\mathrm{PD}$ (Polymeropoulos et al. 1997).

\section{$P D$-linked genes and their interactome}

Genetic studies have shown that 5-10\% of PD patients suffer from a monogenic heritable form of the disease. Alterations of their expression has also been linked to idiopathic PD (Table 2).

$\alpha$-synuclein

$\alpha$-synuclein is of particular interest in respect with PD for mainly two reasons: as the first gene reported to contain specific genetic aberration linked to $\mathrm{PD}$ (Polymeropoulos et al. 1997), 
and as one of the main component of Lewy bodies(Wakabayashi et al. 2013), reflecting its propensity to aggregate. Interestingly, the analysis of sporadic PD brains demonstrated that both soluble and insoluble $\alpha$-synuclein levels are abnormally high in several brain structures(Wills et al. 2010), and at the intracellular level in mitochondria(Devi et al. 2008). According to Desplats(Desplats et al. 2011) et al., this overexpression of $\alpha$-synuclein in PD brain could be the result of hypomethylation. Particularly, they observed that DNA methyltransferase 1 (DNMT1), which controls the methylation status of $\alpha$-synuclein, was sequestered into the cytoplasm and thus decreased nuclear levels in PD.

In the PD brain, increased levels of $\alpha$-synuclein modified through oxidation(Shamoto-Nagai et al. 2007), nitration(Giasson et al. 2000) or cleavage(Dufty et al. 2007) were also observed. This increase in cleaved $\alpha$-synuclein could be the result of increased expression of matrix metalloprotease-3 (MMP3)(Choi et al. 2011). Increased levels of $\alpha$-synuclein phosphorylated at S129 were also detected in PD brain(Mahul-Mellier et al. 2014), possibly the consequence of decreased levels of the SMG1 phosphatidylinositol 3-kinase related kinase(HendersonSmith et al. 2013). Note that G-protein-coupled receptor kinase 5 (GRK5) expression, a protein that phosphorylates $\alpha$-synuclein at S129, remained unchanged in PD brain(Arawaka $e t$ al. 2006). Finally, in the $\mathrm{SN}$ of $\mathrm{PD}$ patients, the $\alpha$-synuclein dimer/monomer ratio is increased(Sharon et al. 2003). This observation could be, at least in part, due to increased levels of tissue transglutaminase in dopaminergic neurons of the SN of PD patients(Wilhelmus et al. 2011b; Citron et al. 2002), which had been shown to catalyze the formation of $\alpha$-synuclein crosslinks(Andringa et al. 2004).

\section{Parkin}

Mutations inducing loss of function of the ubiquitin E3 ligase parkin are the most common known cause of young-onset familial PD(Dawson and Dawson 2010). Like $\alpha$-synuclein, 
parkin was found in Lewy bodies(Schlossmacher et al. 2002). In sporadic PD brains, while total parkin levels remained unchanged(Rubio de la Torre et al. 2009; LaVoie et al. 2005; Wills et al. 2010), its aggregated form was increased(LaVoie et al. 2005), explaining the observed reduction of its soluble form(Lonskaya et al. 2013). The loss of function due to parkin mutations in familial PD is paralleled in sporadic PD by a decrease in parkin availability and thus, activity. Since parkin functions as an E3 ubiquitin ligase to promote the degradation of its substrates via the proteasome, increased levels of parkin substrates should be observed in sporadic PD brain. Consistent with this hypothesis, the parkin substrates aminoacyl-tRNA synthetase-interacting multifunctional protein type 2(Imam et al. 2011; Ko et al. 2010) (AIMP2), also called Jtv1, far upstream element-binding protein-1(Imam et al. 2011; Ko et al. 2010) (FBP-1), parkin interacting substrate(Shin et al. 2011) (PARIS), programmed cell death-2 isoform 1(Fukae et al. 2009) (PDCD2-1) and striatal-enriched protein tyrosine phosphatase 61 (STEP61(Kurup et al. 2015)) were all found to accumulate in the SN or the striatum of PD brain. Of interest, increased levels of S-nitrosylated parkin(Sunico et al. 2013; Chung et al. 2004) were also observed in parkinsonian brain, a modification thought to decrease its E3 ubiquitin ligase activity(Chung et al. 2004). Moreover, increased phosphorylated parkin levels were also observed(Ko et al. 2006; Imam et al. 2011; Rubio de la Torre et al. 2009). This observation is of importance since phosphorylation inactivates parkin ubiquitin ligase function. According to several studies(Mahul-Mellier et al. 2014; Imam et al. 2011; Ko et al. 2006), this increased phosphorylation status would be the consequence of the increased level and activity of the non-receptor tyrosine kinase c-Abl. Finally, the parkin interactor nucleus accumbens 1 (NAC1) aggregated with parkin in dopaminergic neuron of the SN of PD patients(Korutla et al. 2014). 


\section{Other proteins associated with familial PD}

Other proteins found associated with familial PD also presented abnormalities in the idiopathic form of the disease. PTEN-induced putative kinase 1(Muqit et al. 2006) (PINK1) and leucine-rich repeat kinase 2(Cho et al. 2013; Guerreiro et al. 2013) (LRRK2) levels are increased in the brain of PD patients, while ubiquitin C-terminal hydrolase-1 (UCHL-1) levels were found reduced in the SN(Barrachina et al. 2006). Interestingly, oxidized levels of DJ-1, which is considered as an oxidative stress sensor, are elevated in PD dopaminergic neurons(Choi et al. 2014). Of interest, levels and distribution of vacuolar protein sorting 35 homolog (VPS35), a component of retromer, remained unchanged in PD brain(Tsika et al. 2014).

\section{Transition metals, calcium and calcium-binding proteins}

\section{Transition metals}

Several studies indicate that metal homeostasis, particularly iron, is disrupted in PD (Table 3). Indeed, reports using different technologies indicated that iron levels are significantly increased in the SN of PD patients(Dexter et al. 1989; Ayton et al. 2013; Hirsch et al. 1991) and in the dopaminergic neurons populating this brain area(Oakley et al. 2007; Jellinger et al. 1992; Good et al. 1992), more precisely $\mathrm{Fe}^{3+}$ ion levels(Riederer et al. 1989). Increased iron has been linked to other pathogenetically relevant features of PD including oxidative stress and mitochondrial function(Mann et al. 1994). Moreover, several proteins that bind to or transport iron are also deregulated: the expression of such iron transport machinery like divalent metal transporter 1(Salazar et al. 2008) (DMT1), transferrin(Mastroberardino et al. 2009), Nedd4 family interacting protein 1(Howitt et al. 2014) (NDFIP1), a protein implicated in the posttranslational control of DMT1, the iron export protein ferroportin(Visanji et al. 
2013), as well as the iron-binding proteins ferritin(Riederer et al. 1989), lactoferrin(Rousseau et al. 2013; Leveugle et al. 1996) and its receptor(Faucheux et al. 1995) are all increased in the SN of PD patients. Interestingly, ceruloplasmin, a protein acting as an iron-export ferroxidase, showed a decreased activity in the SN(Howitt et al. 2014).

Iron is not the only metal found dysregulated in PD. Total copper content is also decreased in the SN of PD patients(Dexter et al. 1989; Ayton et al. 2013), as well as the copper transporter 1 (CTR1). Interestingly, metallothioneins, proteins controlling the bioavailability of metals, including copper, were found to be overexpressed in the SN of PD patients. Aluminium and zinc content are increased in the SN of PD patients(Good et al. 1992; Hirsch et al. 1991), while manganese content is reduced in their putamen(Dexter et al. 1989).

\section{Calcium and calcium-binding proteins}

Calcium appears to be crucial for dopaminergic neuron survival since those of the SNpc expressing calbindin D-28K are less susceptible to degenerate in PD(Yamada et al. 1990). While total $\mathrm{Ca}^{2+}$ levels remain normal in PD (Table 3), voltage-gated $\mathrm{Ca}^{2+}$ channel (Cav) 1.2 and 1.3 levels are reduced in the SN of PD patients(Hurley et al. 2013) but not in their striatum(Watson et al. 1988). Parvalbumin levels, a protein expressed as a defensive response against $\mathrm{Ca}^{2+}$ stress, were also increased(Soós et al. 2004). There are conflicting reports on calcium binding proteins calbindin, calmodulin and calreticulin(Reynolds et al. 2008; Hurley et al. 2013; Wilhelmus et al. 2011b) while $\mathrm{Ca}^{2+}$-dependent protein kinase (PKC) levels are decreased(Tanaka et al. 1993). The calcium dependent-protease calpain II is expressed by a larger number of neurons in the SN of PD patients(Mouatt-Prigent et al. 1996), contrary to its inhibitor calpastatin(Mouatt-Prigent et al. 2000). Finally, lipocortin-1, a $\mathrm{Ca}^{2+}$-binding protein that buffers intracellular calcium involved in microglial activation, was reported to be 
expressed by microglial cells, suggesting an ongoing inflammatory response(Knott et al. 2000).

\section{Inflammation}

While the central nervous system (CNS) is considered to be a relatively immune-privileged tissue, it is still able to initiate an immune response. This immune response is mediated by glial cells, usually initiated by microglial cells, the resident tissue macrophages of the CNS, and then amplified by astrocytes(Halliday and Stevens 2011). To maintain proper tissue homeostasis and to avoid collateral tissue damage during inflammatory reactions, all of the inflammatory responses must eventually be terminated. However, several studies indicate that an inflammatory response is ongoing in the parkinsonian brain (Table 4).

In PD brains, the number of microglial cells is increased(Lastres-Becker et al. 2012; Imamura et al. 2003) in comparison to control brains. Moreover, these cells are activated since the number of microglial cells expressing activation markers like HLA-DR(Orr et al. 2005; Imamura et al. 2003; Imamura et al. 2005), ICAM-1(Imamura et al. 2003), CD68(Vroon et al. 2007), lymphocyte function-associated antigen 1(Miklossy et al. 2006) (LFA-1), activated caspase-3/8(Burguillos et al. 2011), CD23(Hunot et al. 1999) or CD163(Pey et al. 2014) is also increased. Interestingly, microglial cells in PD brain express C1q(Depboylu et al. 2011), which is implicated in the clearance of apoptotic cells through phagocytosis. Additionally, increased levels of glucocorticoid receptors(Ros-Bernal et al. 2011), a regulator of inflammation, nitric oxide synthase(Hunot et al. 1996) (NOS) and inducible NOS(Knott et al. 2000) (iNOS), expression of which is increased during inflammatory events, as well as lipocortin-1(Knott et al. 2000), an anti-inflammatory molecule, were detected in microglial cells in PD brain. 
In contrast to microglial cells, the activated status of astrocytes is more controversial in brains of PD patients, since some studies detect astrogliosis through increased expression of GFAP(Mythri et al. 2011; Lastres-Becker et al. 2012) or ICAM-1(Miklossy et al. 2006) while others did not(Mirza et al. 1999; Tong et al. 2015). However, whether astrogliosis is triggered or not, inflammatory events seemed to affect astrocytes since increased levels of myeloperoxidase(Choi et al. 2005a), a key oxidant-producing enzyme during inflammation, milk fat globule-EGF factor 8 (Kinugawa et al. 2013) (MFGE8), a factor involved in phagocytic recognition, as well as heme oxygenase-1(Schipper et al. 2009) (HO-1), an antioxidant enzyme involved in the regulation of the inflammatory process, were reported specifically in astrocytes in the parkinsonian brain. Importantly, infiltration of peripheral immune cells could also participates in the neuroinflammatory response in PD since LFA-1positive leukocytes(Miklossy et al. 2006), CD8-positive and CD4-positive T cells(Brochard et al. 2009) were found in the SN of PD patients.

Inflammatory response can be harmful for the neuronal cells because of the release of proinflammatory agents. In the parkinsonian brain, higher levels of cytokines like interleukin (IL) 1ß(Mogi et al. 1994a; Hunot et al. 1999) (IL-1ß), IL-2(Mogi et al. 1996b), IL-6(Mogi et al. 1994a), tumor necrosis factor $\alpha$ (Mogi et al. 1994b; Hunot et al. 1999) (TNFa), S100B(Sathe et al. 2012), interferon y(Mogi et al. 2007; Hunot et al. 1999) and its receptor(Hashioka et al. 2009), as well as chemokine (C-X-C motif) ligand 12 (CXCL12) and its receptor C-X-C chemokine receptor type 4(Shimoji et al. 2009) (CXCR4) were detected. Finally, at the neuronal level, inflammation appears ongoing since dopaminergic neurons of the SN express higher levels of cyclooxygenase-2(Teismann et al. 2003), the rate-limiting enzyme in prostaglandin E2 synthesis. Moreover, the nuclear fraction of $\mathrm{NF}-\kappa \mathrm{B}$, a transcription factor activated during inflammatory response, is increased in the same neuronal population(Soós et al. 2004). 


\section{Mitochondrial abnormalities and oxidative stress}

\section{Mitochondrial abnormalities and energy deficits}

Mitochondria play a prominent role in energy metabolism and many lines of evidence suggest mitochondrial dysfunctions and energy deficits in PD (Table 5). The first studies on mitochondrial dysfunction in PD documented deficiency of mitochondrial Complex I in the PD SN(Schapira et al. 1989; Schapira et al. 1990). Subsequent analyses have confirmed the important role of Complex I in PD(Morais et al. 2014). Other studies observed deregulated expression of several mitochondrial proteins in PD brain e.g. the molecular chaperones prohibitin(Ferrer et al. 2007), the outer mitochondrial membrane VDAC1(Chu et al. 2014), the mitochondrial import machinery translocase of outer membrane 40 TOM40(Bender et al. 2013), the serine protease HtrA2(Plun-Favreau et al. 2007), or hemoglobins $\alpha$ and $\beta$ (Ferrer et al. 2011; Shephard et al. 2014). The PD associated protein parkin and PINK1 would also play a key role in mitochondrial dynamics (for review see (Pickrell and Youle 2015)). In this respect, AF6, a key regulator of PINK1/parkin-mediated autophagy, is less expressed in the SN of PD patients. Glucose metabolism is dysregulated in PD, particularly with the increased levels of pentose phosphate pathway enzymes glucose-6-phosphate dehydrogenase (G6PD) and 6-phosphogluconate dehydrogenase (6PGD) leading to elevated production of NADPH, a sign of oxidative stress(Dunn et al. 2014).

Finally, total and mitochondrial oxygen uptake(Navarro et al. 2009) is reduced. This is consistent with the evidences for impaired oxidative phosphorylation in PD brain samples(Keeney et al. 2006; Parker et al. 2008; Hattori et al. 1993; Navarro et al. 2009; Schapira et al. 1990; Schapira et al. 1989). Three reasons are evoked to explain this observation: complex I expression seemed to be reduced(Moisoi et al. 2009; Keeney et al. 2006), particularly the NADH dehydrogenase 6 subunit(She et al. 2011) (ND6); catalytic 
subunits of complex I were found to contain oxidized proteins(Keeney et al. 2006); mitochondrial DNA may develop some mutations in PD (including the mitochondrial polymerase gamma gene(Orsucci et al. 2011)), which could explain defects in mitochondrial respiration(Sanders et al. 2014; Bender et al. 2006; Lin et al. 2013). ATP synthase levels have been reported to be reduced in the SN of PD patients(Ferrer et al. 2007). As a consequence of the deficit of mitochondrial electron transport chain, high-energy phosphates such as ATP and phosphocreatine as final acceptors of energy from mitochondrial oxidative phosphorylation are reduced. In contrast, low-energy metabolites such as ADP and inorganic phosphate were within normal ranges(Hattingen et al. 2009). Since complex I is considered as one of the main source of reactive oxygen species in the cell, its abnormal function could lead to increased oxidative stress. This could explain the observed increase in the oxidative damage of mitochondrial proteins(Navarro et al. 2009).

\section{Oxidative stress}

A large number of studies indicate that oxidative stress is considered as a major contributing factor in the pathogenesis of PD (Table 5). The levels of total oxidized proteins(Alam et al. 1997; Choi et al. 2005b; Yoritaka et al. 1996; Mythri et al. 2011) are highly increased in several brain areas, either through carbonylation or nitrosylation, and more particularly mitochondrial proteins(Shimura-Miura et al. 1999; Navarro et al. 2009). Moreover, oxidative stress sensor of nucleolar integrity is disrupted in dopaminergic neurons of the SN(Rieker et al. 2011), while Nrf2 (nuclear factor erythroid 2-related factor 2), which is translocated into the nucleus in response to oxidative stress, shows increased nuclear and reduced cytoplasmic levels(Ramsey et al. 2007). Antioxidant proteins levels and activities are particularly deregulated: biliverdin reductase(Reynolds et al. 2008), superoxide dismutase (SOD)(Radunović et al. 1997; Marttila et al. 1988; Choi et al. 2005b; Ferrer et al. 2007; 
Navarro et al. 2009), sestrin-2(Zhou et al. 2013), selenoprotein P(Bellinger et al. 2012), osteopontin(Maetzler et al. 2007), NAD(P)H quinone oxidoreductase(van Muiswinkel et al. 2004), MTH1(Nakabeppu et al. 2007), MUTYH(Arai et al. 2006; Shimura-Miura et al. 1999) (mutY Homolog), nitrosylated peroxiredoxin-2(Fang et al. 2007), levels and/or activities are increased, while catalase and peroxidase activity(Ambani et al. 1975) are decreased. This decrease in peroxidase activity can be controlled through phosphorylation. Interestingly, phosphorylated peroxyredoxin-2 and 3 levels are increased in the PD brain(Qu et al. 2007; Angeles et al. 2011).

The glutathione system, which is responsible for the detoxification of reactive oxygen and nitrogen species, appeared to be deregulated in PD patients. While oxidized glutathione levels are normal, reduced glutathione levels are severely decreased in the SN of PD patients(Sian $e t$ al. 1994; Pearce et al. 1997; Riederer et al. 1989). Moreover, several enzymes of the glutathione system including y-glutamyltranspeptidase(Mythri et al. 2011; Sian et al. 1994), glutathione peroxidase(Power et al. 2002; Mythri et al. 2011), glutathione-Stransferase(Reynolds et al. 2008) levels and/or activities are altered in the PD brain.

One consequence of oxidative stress in PD is DNA damage. Indeed, in PD patients, DNA is severely oxidized(Du et al. 2009), and mitochondrial and nuclear DNA presented a higher number of mutations(Zhang et al. 2002; Ozawa et al. 1997; Lin et al. 2013; Sanders et al. 2014; Bender et al. 2006) than control brains. In response to DNA damage, defense mechanisms against oxidative damage to nucleic acids involving MTH1(Shimura-Miura et al. 1999), MUTYH(Arai et al. 2006) and OGG1 (8-oxoguanine DNA-glycosylase 1) (Fukae et al. 2005) as well as DNA repair proteins such as poly(ADP-ribose) polymerase(Soós et al. 2004) (PARP), TNF Receptor Associated Protein(Vilotti et al. 2012) (TRAPP), DNA polymerase $\delta$ (Camins et al. 2010) and ataxia telangiectasia muted(Camins et al. 2010) (ATM) are activated in PD brain. 


\section{Abnormal protein removal and degradation}

The ubiquitin-proteasome system (UPS) and autophagy-lysosome pathway (ALP) are the two most important cellular mechanisms that repair or remove abnormal proteins(Korolchuk et al. 2010). Since PD is characterized by the presence of misfolded and aggregated proteins that forms Lewy bodies, alterations in abnormal protein removal could be implicated in its pathogenesis through impairment of either UPS, ALP, or both mechanisms (Table 6).

\section{Ubiquitin-proteasome system (UPS)}

The UPS is the principal mechanism for protein catabolism in the mammalian cytosol and nucleus. Degradation of a protein via the UPS involves two steps: the conjugation, which consists in the covalent attachment of ubiquitin molecules to the substrate protein, and the subsequent degradation of the tagged protein by the proteasome(Korolchuk et al. 2010). Several lines of evidence obtained from the postmortem study of PD brains suggest that the UPS is dysregulated in this pathology (Table 6). First, total ubiquinated protein level is dramatically increased in the striatum of PD patients(Lonskaya et al. 2013). This could be the result of defective expression of several ubiquitin ligase or deubiquitinase. In line with this hypothesis, SKP1A(Mandel et al. 2007) (S-phase kinase-associated protein 1A), NEDD4(Tofaris et al. 2011) (neural precursor cell expressed, developmentally downregulated 4), USP9X(Rott et al. 2011) (ubiquitin specific peptidase 9, X-linked) and TRIM9(Tanji et al. 2010) (tripartite motif containing 9) have been shown to be deregulated in the $\mathrm{SN}$ of parkinsonian brains. Also, parkin, a protein encoded by a gene that when mutate, is associated with familial PD, possesses ubiquitin ligase activities(Seirafi et al. 2015). 
The increase in total ubiquinated protein level could also be explained by proteasomal dysfunctions. Indeed, the activity of the $26 \mathrm{~S}$ proteasome is decreased in several structures of the parkinsonian brain(Wills et al. 2010). The 20S proteasome, which correspond to the catalytic core of the protein complex, is also underexpressed(McNaught and Jenner 2001; Chu et al. 2009; Wills et al. 2010), explaining its weaker chymotriptic, tryptic and postacidic activities(McNaught et al. 2003; McNaught and Jenner 2001) in the SN of PD brains. More precisely, the $\alpha$-subunit of $20 \mathrm{~S}$ proteasome is underexpressed in this structure(McNaught $e t$ al. 2003), a result confirmed by Bukhatwa et al.(Bukhatwa et al. 2010) who reported that $\alpha 4$ and $\alpha 6$ subunit levels were specifically decreased in dopaminergic neurons of the SN. This decrease in $\alpha$ subunits of the 20S appears to be restricted to the $\mathrm{SN}$ since $\alpha 6$ subunit levels are increased in the striatum(Nakamura et al. 2006). Likewise, the regulatory core of the proteasome called 19S (or PA700) has also been reported to be underexpressed in the SN but overexpressed in the Str(McNaught et al. 2003). PA28 (also known as 11S), an alternate regulator that can replace $19 \mathrm{~S}$ proteasome, did not seem to be involved in the pathology(McNaught et al. 2003).

\section{Lysosome, macroautophagy and chaperone-mediated autophagy (CMA)}

Autophagy is a cellular process by which cytoplasmic materials are delivered to and degraded in the lysosome to maintain cellular homeostasis. Depending on the mode of cargo delivery to the lysosome, autophagy can be subdivided into three subtypes: macroautophagy, microautophagy, and chaperone-mediated autophagy (CMA)(Wu et al. 2014). While microautophagy had not been assessed in parkinsonian brains, evidence suggests that macroautophagy, CMA and lysosomal degradation are deregulated in PD patients (Table 6). Macroautophagy, which is the most universal form of autophagy, is characterized by the formation of autophagosomes that are capable of disposing of protein aggregates and 
damaged organelles(Korolchuk et al. 2010). Macroautophagy appears to be implicated in PD pathogenesis since several key proteins driving this cellular process are deregulated. Beclin-1, which is responsible for the formation and the maturation of autophagosomes, is increased in the SN of PD patients(Rohn and Catlin 2011; Miki et al. 2015), as well as LC3II(Dehay et al. 2010), an autophagosome marker. However, no difference was observed between control and PD levels of unc-51 like autophagy activating kinase 1 (ULK1), ULK2 or phosphatidylinositol 3-kinase VPS34(Miki et al. 2015). In contrast to autophagy, CMA is a process by which selected cytosolic proteins are directly targeted to the lysosome for degradation (for more details see (Kaushik and Cuervo 2012)). Impairment of CMA function is implicated in PD pathogenesis since heat shock cognate 70(Alvarez-Erviti et al. 2010; Mandel et al. 2009) (HSC70), a protein responsible for the translocation of targeted substrate into the lysosome, as well as its lysosomal surface receptor lysosomal-associated membrane protein 2(Murphy et al. 2014; Alvarez-Erviti et al. 2010) (LAMP2) are less expressed in several structures of PD brain. This deficit in CMA in PD brain could explain why levels of MEF2D (myocyte enhancer factor 2D), a transcription factor degraded through CMA, are increased in the striatum of PD patients(She et al. 2011).

At the lysosomal level, Anglade and coworkers(Anglade et al. 1997) observed that the number of autophagic vacuoles is drastically decreased in the dopaminergic neurons of PD SN. At the molecular level, lysosomal markers like the structural protein Lysosome Associated Membrane Protein 1(Chu et al. 2009; Dehay et al. 2010) (LAMP1), the lysosomal P-type ATPase ATP13A2(Dehay et al. 2012), glucocerebrosidase(Gegg et al. 2012; Murphy et al. 2014) and its interacting partner lysosomal integral membrane protein type-2(Rothaug et al. 2014) (LIMP-2) as well as Heat Shock Protein 73(Chu et al. 2009) (HSP73), all were decreased in the SN of PD patients. Moreover, several enzymes that participate in the degradation of proteins (Cathepsins A(Murphy et al. 2014), B(Mantle et al. 1995), D(Murphy 
et al. 2014; Chu et al. 2009; Mantle et al. 1995), H(Mantle et al. 1995), L(Mantle et al. 1995), and dipeptidyl aminopeptidase(Mantle et al. 1996)) had abnormal levels or activities. Interestingly, the expression of two transcription factors crucially involved in the ALP, namely transcription factor EB(Decressac et al. 2013) (TFEB) and LMX1B(Laguna et al. 2015) (LIM homeobox transcription factor 1 beta), were found to be reduced in the dopaminergic neurons of the SN of PD patients.

\section{Apoptosis and transduction pathways}

Several lines of evidence suggest that neurons degenerate mostly through an apoptotic pathway in PD. The SN of PD patients contains hallmarks of apoptosis, such as nuclear condensation, chromatin fragmentation(Tompkins et al. 1997) or TUNEL (terminal deoxynucleotidyl transferase dUTP nick end labeling) positive cells(Mochizuki et al. 1996). At the molecular level, two different routes can trigger caspase-mediated apoptotic processes: the intrinsic and the extrinsic apoptotic pathway (Table 7). Since the intrinsic apoptosis pathway is activated following intracellular events such as ER stress or cell cycle re-entry, we will first review these topics.

\section{ER stress}

ER is recognized as the site of synthesis and folding of proteins. Abnormalities in ER functions lead to the accumulation and aggregation of unfolded proteins. To avoid this protein accumulation, transmembrane receptors located in the ER detect the onset of ER stress and activate the unfolded protein response (UPR). If UPR fails in reinstating normal ER function, apoptotic cell death ensues (for review see (Szegezdi et al. 2006)). Few studies have focused on ER stress and UPR markers in PD brains (Table 7). Hoozemans et al. showed that an increased number of dopaminergic neurons of the SN express the UPR activation markers 
phosphorylated pancreatic ER kinase (PERK) and phosphorylated eukaryotic initiation factor $2 \alpha(\mathrm{eIF} 2 \alpha)($ Hoozemans et al. 2007), as well as phosphorylated inositol-requiring enzyme 1 (IRE1 $\alpha)($ Hoozemans et al. 2012). In another study, increased nuclear levels of activated, phosphorylated double-strand RNA dependent protein kinase (PKR), a kinase which activates eIF2 $\alpha$, were also reported(Bando et al. 2005). Finally, homocysteine-induced endoplasmic reticulum protein (HERP), a stress-response protein localized in the ER membrane, is also overexpressed in the SN of PD patients(Slodzinski et al. 2009).

\section{Cell cycle re-entry}

Recent results indicate that re-entry into the cell cycle may constitute a common pathway involved during neurodegeneration(Folch et al. 2012). Consistent with this hypothesis (Table 7), neurons with extra copies of chromosomes 18 and X(Höglinger et al. 2004) as well as increased levels of normal and phosphorylated retinoblastoma protein $(\mathrm{pRb})$, a molecular trigger of cell-cycle progression, were observed in dopaminergic neurons in the postmortem SN of PD patients(Jordan-Sciutto et al. 2003). Moreover, p25/Cdk5 (cyclin-dependent kinase 5), which phosphorylates $\mathrm{pRb}($ Hamdane et al. 2005), is overexpressed in $\mathrm{PD}$ (Alvira et al. 2008; Rubio de la Torre et al. 2009), as well as the Cdk5 activator p35(Rubio de la Torre et al. 2009). In line with this view, SN dopaminergic neurons of PD patients has been shown to be immunoreactive for proliferating cell nuclear antigen(Höglinger et al. 2004) (PCNA), a subunit of DNA polymerase, E2F-1, a mitosis-linked transcription factor(Höglinger et al. 2004; Alvira et al. 2008), and cyclin D1(Camins et al. 2010).

\section{Intrinsic apoptotic pathway}

Cellular stress such as ER stress or DNA damage activates B cell lymphoma 2 (BCL-2) homology 3 (BH3)-only proteins leading to BCL-2-associated X protein (Bax) activation. 
Interestingly, Bax levels were shown to be increased specifically in dopaminergic neurons(Tatton 2000), and in Lewy body containing neurons(Hartmann et al. 2001a). The anti-apoptotic Bcl-2, which binds activated Bax, was shown to be overexpressed in several structures of PD brains(Letters et al. 1996; Marshall et al. 1997). Once activated, Bax triggers mitochondrial outer membrane permeabilisation. As a consequence, cytochrome $\mathrm{c}$ is released into the cytosol. In PD SN and LC, neurons exhibit a higher level of cytochrome c(Kawamoto et al. 2014). Moreover, total cytochrome c content is increased in PD temporal cortex while mitochondrial content is decreased(Jiang et al. 2012). Consistent with a permeabilisation of the mitochondrial membrane, endonuclease G, a mitochondrial pro-apoptotic nuclease, is also found in the nucleus of PD dopaminergic neurons(Büttner et al. 2013). Once released in the cytosol, cytochrome c binds apoptotic protease-activating factor 1 (APAF1), inducing its oligomerization and thereby forming a structure termed the apoptosome that recruits and activates an initiator caspase, caspase 9. In TH neurons of PD SN, increased levels of both APAF1(Kawamoto et al. 2014) and activated caspase-9(Viswanath et al. 2001; Kawamoto et al. 2014) have been reported. When activated, caspase-9 cleaves and recruits executioner caspase-3, leading to apoptosis. In PD brain, caspase-3 activity(Mogi et al. 2000) and levels(Tatton 2000; Jiang et al. 2012) are increased in the SN and temporal cortex. In contrast to these observations, Hartmann et al.(Hartmann et al. 2000) observed a significant decrease of caspase-3-positive pigmented neurons in the SNpc of PD patients compared to controls, interpreted as an increased sensitivity to the pathological process of caspase- 3 containing neurons. Finally, p53 and its active, phosphorylated form (pp53), a transcription factor that controls the expression and the activation of several proteins implicated in the apoptotic process (including Bax and Apaf1), is overexpressed in several brain areas of PD patients(Mogi et al. 2007; Sunico et al. 2013; Camins et al. 2010). 


\section{Extrinsic pathway}

The activation of the extrinsic apoptotic pathway depends on external factors(Elmore 2007) that as previously mentioned, could be involved in PD pathogenesis, such as neurotrophic factor deprivation or inflammation. During inflammatory episodes, cytokines and proinflammatory agents like TNF- $\alpha$ or FasL are released by glial cells. These pro-inflammatory agents can trigger the extrinsic apoptotic pathway by interacting with TNF receptor (TNFR) family. Interestingly, in PD postmortem brains, TNF receptor I (TNFRI, also known as p55) and its effector protein TNFR1-associating protein with a death domain (TRADD) levels have both been shown to be increased in the SN(Mogi et al. 2000) and the temporal cortex(Jiang et al. 2012). Reduced expression of Fas, another receptor potentially responsible for the activation of the extrinsic apoptotic pathway, and its ligand FasL have been observed in neurons of the SN of PD patients, while their levels were increased in reactive astrocytes of the same structure(Ferrer et al. 2000). Mogi(Mogi et al. 1996a) et al., showed that soluble Fas expression was increased in the caudate nucleus and putamen of parkinsonian brains. Moreover, levels of Fas-associated factor-1, which can serve as an enhancer of apoptosis initiated through Fas, was overexpressed(Betarbet et al. 2008).

Activation of TNFRI or Fas by pro-inflammatory agents converges with the activation by cleavage of caspase- 8 . Increased levels of activated caspase- 8 have been observed in dopaminergic neurons of the SN in PD patients(Viswanath et al. 2001), and an increased number of $\mathrm{TH}$ neurons of the same structure expressing activated caspase- 8 was also reported(Hartmann et al. 2001b). Of interest, the number of TH neurons expressing Fasassociating protein with a death domain (FADD), which participates in the auto-proteolytic cleavage of caspase- 8 , is reduced in the SN of PD patients, suggesting that these neurons are more prone to degeneration(Hartmann et al. 2002). Once activated, caspase- 8 may in turn cleave effector caspases such as caspase-3 or caspase-1, whose activities are increased in the 
SN of PD patients(Mogi et al. 2000). Moreover, Bid and its post-translationally activated, truncated form tBid through caspase-8-mediated cleavage, are also increased in the cytoplasm and mitochondria of PD brains(Jiang et al. 2012).

\section{Other form of cell death}

Lee and coworkers(Lee et al. 2013) demonstrated that parthanatos, a form of cell death induced by excessive poly-ADP-ribose polymers, could be implicated in PD since the level of these polymers is strongly increased as well as AIMP2, which is thought to mediate parthanatos-induced cell death.

\section{Transduction pathways and transcription factors}

Several changes in the activation of transcription factors and transduction pathways occur in PD brain (Table 7). Since cellular stress might be of great importance in PD pathogenesis, many studies focused on nuclear factor-kappa B (NF- $\mathrm{kB})$, a transcription factors involved in cellular responses to inflammation and oxidative stress(Morgan and Liu 2011). Many lines of evidence suggest that $\mathrm{NF}-\kappa \mathrm{B}$ is activated in PD. First, negative regulator of NF- $\kappa \mathrm{B}$ activation like RING finger protein 11 (RNF11) has reduced expression in PD(Pranski et al. 2013). Total NF-אB levels were found elevated in the SN of PD patients(Mogi et al. 2007), as well as its constituting subunit p50(Reynolds et al. 2008) and p65(Ghosh et al. 2009; Reynolds et al. 2008). These increased levels were found in the cytosol as well as in the nucleus(Reynolds et al. 2008). Interestingly, increased nuclear levels are reported in the dopaminergic neurons of the SN of PD patients(Hunot et al. 1997; Soós et al. 2004). Moreover, levels of normal and phosphorylated p53 protein, known to be involved in apoptosis, are increased in PD brains(Mogi et al. 2007; Folch et al. 2012; Sunico et al. 2013). 
Akt, a prosurvival factor(Zhang et al. 2011), appears to be involved in the pathogenesis of PD since its midbrain levels are significantly reduced(Timmons et al. 2009). This was also observed in TH neurons of the SN(Malagelada et al. 2008), and phosphorylated levels of

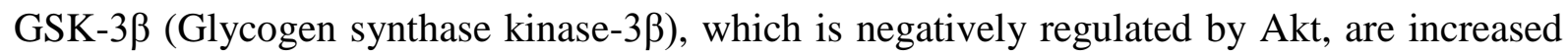
in PD striatum(Wills et al. 2010). Importantly, levels of S473-phosphorylated (activated) Akt were reduced in this neuronal population(Malagelada et al. 2008) in TH neurons. To explain this observation, Malagelada et al. suggested the involvement of Redd1, an endogenous inhibitor of Akt expression and activation, which levels are increased in the parkinsonian SN(Malagelada et al. 2008).

The microtubule-associated protein kinase (MAPK) pathway is important for cell

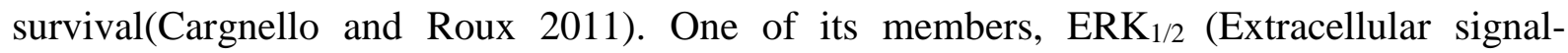
regulated kinase 1/2), and its downstream target CREB (cAMP response element-binding) were reported as less phosphorylated in PD striatum(Kurup et al. 2015). Contrasting results were observed in the frontal cortex of PD patients(Price et al. 2010). Two other members of the MAPK family, the prodeath c-Jun N-terminal kinase (JNK) and p38, displayed increased levels in the SN of PD patients(Hu et al. 2011). Accordingly, Hunot et al. reported increased activated JNK downstream target c-jun in PD dopaminergic neurons(Hunot et al. 2004). Of interest, apoptosis signal-regulating kinase 1 (ASK1), which regulated the activation of both JNK and p38, was also found to be more activated(Hu et al. 2011). Moreover, membrane levels of $14-3-3 \zeta$ phosphorylated at S58, which causes release of the pro-apoptotic protein ASK1 and cell death in response to oxidative stress(Zhou et al. 2009), are decreased in PD patients(Slone et al. 2015). Finally, a number of other transcription factors crucially involved in cell survival following cellular stress such as PGC1 $\alpha($ Eschbach et al. 2015; Shin et al. 2011) (peroxisome proliferator-activated receptor gamma, coactivator 1 alpha), MEF2D(Gao et al. 2014; Chu et al. 2011; She et al. 2011) or Nurr1(Chu et al. 2006) (Nuclear receptor 
related 1) are underexpressed in PD brain, while Nfatc4 (Nuclear Factor Of Activated T-Cells, Cytoplasmic, Calcineurin-Dependent 4) nuclear localization is increased(Caraveo et al. 2014).

\section{Other proteins}

Expression of several other proteins have also been shown to be altered in PD and in particular structural and cytoskeleton proteins. Connexin-36(Schwab et al. 2014) and $\alpha$ tubulin(Reynolds et al. 2008) levels are increased, while actin(Reynolds et al. 2008) and Lplastin(Reynolds et al. 2008) are reduced. Abnormal microtubule-associated protein 2 (MAP2) nuclear labelling has been reported(D'Andrea et al. 2001). Of interest, tau phosphorylation status is, as in Alzheimer's disease, highly modified(Duka et al. 2013; Wills et al. 2010). Levels of synaptic proteins like the SNARE assembly complex(Sharma et al. 2012), SNAP25 or syntaxin-1(Garcia-Reitböck et al. 2010)are all modified as well as extracellular matrix components MMP-2 (matrix metalloprotease 2) and TIMP-1(Lorenzl et al. 2002) (TIMP Metallopeptidase Inhibitor 1), lipid transporters apolipoprotein (apo) D(Ordoñez et al. 2006) (ApoD), E(Wilhelmus et al. 2011a) (ApoE) and ApoE receptor LRP1(Wilhelmus et al. 2011a). Finally, the expression of several phospholipid biosynthetic enzymes as calciumstimulated phospholipase A2, phosphatidylserine synthase, phosphocholinecytidylyltransferase and phosphoethanolaminecytidylyltransferase are also increased(Ross et al. 2001).

\section{Incidental Lewy body disease}

Incidental Lewy body disease (ILBD) is usually considered as a prodromal state of PD characterised by the absence of motor symptoms but the presence of a variety of non-motor abnormalities. At the cellular level, ILBD is characterised by a moderate nigral neuronal loss(Dijkstra et al. 2014) and Lewy pathology(Iacono et al. 2015), decreased striatal 
dopaminergic immunoreactivity(DelleDonne et al. 2008; Dickson et al. 2008; Beach et al. 2008), olfactory bulb abnormalities(Driver-Dunckley et al. 2014), and microglial activation(Doorn et al. 2014). However, few studies have focused on the molecular changes. L-ferritin and copper levels are decreased(Davies et al. 2014)'(Koziorowski et al. 2007), while mitochondrial DNA mutations(Lin et al. 2012) and Bcl-2(Marshall et al. 1997) levels are increased. Several evidences suggest that oxidative stress and mitochondrial function are also altered in ILBD(Dexter et al. 1994; Dalfó et al. 2005).

\section{Conclusions}

There are comprehensive data derived from postmortem PD brains that have demonstrated that multiple pathways and cellular functions are modified at the molecular level in late-stage pathology. During our review of the literature, we observed that postmortem studies were mainly restricted to the nigrostriatal pathway, while cerebral structures that are affected before this pathway during the course of the disease (i.e. olfactory bulb and medulla oblongata(Goedert et al. 2014)) or where cell loss is also important in the disease (such as locus coeruleus(Zarow et al. 2015) and pedunculopontine nucleus(Hirsch et al. 1987)) are poorly studied at the molecular level. This is a disadvantage in our efforts to understand the effects of pathogenesis on non-dopaminergic systems and in particular the biochemical changes that underlie non-motor features in PD. In addition, there is an opportunity by this means to investigate areas 'ahead of the pathology' i.e. those regions that might be affected by early molecular derangements, but not neurodegeneration. This would provide insight into the evolving nature of the molecular pathogenesis of $\mathrm{PD}$, and represent the same principle as addressed in those studies on Incidental Lewy Body disease (see above) but in pathologically

proven PD brain. Animal studies in PD field focus exclusively on nigrostriatal cell 
degeneration and death, which could somehow explain the high rate failure of drugs that were tested successfully in animal models but failed clinically in PD patients.

On the other hand, while postmortem brain studies represent an efficient way to improve our understanding of the pathology, it also presents some limitations. The sample size is often limited because it is still difficult to obtain brain tissue, and postmortem delay will affect the quality of tissues, and thus the preservation of proteins especially when some are more vulnerable than others(Ferrer et al. 2008). Braak stage of collected postmortem brains is also usually highly heterogeneous, challenging further comparisons. These factors, together with heterogeneity of PD could render the interpretation of postmortem studies very difficult, even sometimes uncertain if sampling is not rigorously performed.

\section{Acknowledgements}

The authors would like to thank Ilya Chumakov for his critical review of the manuscript.

\section{Conflicts of interest}

The authors declare no conflicts of interest. 


\section{References}

Ahlskog J. E., Richelson E., Nelson A., Kelly P. J., Okazaki H., Tyce G. M., Heerden J. a van, Stoddard S. L., Carmichael S. W. (1991) Reduced D2 dopamine and muscarinic cholinergic receptor densities in caudate specimens from fluctuating parkinsonian patients. Ann. Neurol. 30, $185-191$.

Aksenova M. V., Aksenov M. Y., Payne R. M., Trojanowski J. Q., Schmidt M. L., Carney J. M., Butterfield D. A., Markesbery W. R. (1999) Oxidation of cytosolic proteins and expression of creatine kinase BB in frontal lobe in different neurodegenerative disorders. Dement. Geriatr. Cogn. Disord. 10, 158-165.

Alam Z. I., Daniel S. E., Lees A. J., Marsden D. C., Jenner P., Halliwell B. (1997) A generalised increase in protein carbonyls in the brain in Parkinson's but not incidental Lewy body disease. $J$. Neurochem. 69, 1326-9.

Allen A. M., MacGregor D. P., Chai S. Y., Donnan G. A., Kaczmarczyk S., Richardson K., Kalnins R., Ireton J., Mendelsohn F. A. (1992) Angiotensin II receptor binding associated with nigrostriatal dopaminergic neurons in human basal ganglia. Ann. Neurol. 32, 339-344.

Alvarez-Erviti L., Rodriguez-Oroz M. C., Cooper J. M., Caballero C., Ferrer I., Obeso J. A., Schapira A. H. V. (2010) Chaperone-Mediated Autophagy Markers in Parkinson Disease Brains. Arch. Neurol. 67, 1464-1472.

Alvira D., Ferrer I., Gutierrez-Cuesta J., Garcia-Castro B., Pallàs M., Camins A. (2008) Activation of the calpain/cdk5/p25 pathway in the girus cinguli in Parkinson's disease. Parkinsonism Relat. Disord. 14, 309-13.

Ambani L. M., Woert M. H. Van, Murphy S. (1975) Brain peroxidase and catalase in Parkinson disease. Arch. Neurol. 32, 114-8.

Andringa G., Lam K. Y., Chegary M., Wang X., Chase T. N., Bennett M. C., Branch E. T., Neurosciences B. R. (2004) Tissue transglutaminase catalyzes the formation of alpha-synuclein crosslinks in Parkinson's disease. FASEB J. 18, 932-934.

Angeles D. C., Gan B.-H., Onstead L., Zhao Y., Lim K.-L., Dachsel J., Melrose H., et al. (2011) Mutations in LRRK2 increase phosphorylation of peroxiredoxin 3 exacerbating oxidative stressinduced neuronal death. Hum. Mutat. 32, 1390-7.

Anglade P., Vyas S., Javoy-Agid F., Herrero M. T., Michel P. P., Marquez J., Mouatt-Prigent A., Ruberg M., Hirsch E. C., Agid Y. (1997) Apoptosis and autophagy in nigral neurons of patients with Parkinson's disease. Histol. Histopathol. 12, 25-31.

Arai T., Fukae J., Hatano T., Kubo S., Ohtsubo T., Nakabeppu Y., Mori H., Mizuno Y., Hattori N. (2006) Up-regulation of hMUTYH, a DNA repair enzyme, in the mitochondria of substantia nigra in Parkinson's disease. Acta Neuropathol. 112, 139-145.

Arawaka S., Wada M., Goto S., Karube H., Sakamoto M., Ren C.-H., Koyama S., et al. (2006) The role of G-protein-coupled receptor kinase 5 in pathogenesis of sporadic Parkinson's disease. $J$. Neurosci. 26, 9227-38.

Ayton S., Lei P., Duce J. a., Wong B. X. W., Sedjahtera A., Adlard P. a., Bush A. I., Finkelstein D. I. (2013) Ceruloplasmin dysfunction and therapeutic potential for Parkinson disease. Ann. Neurol. 73, 554-559.

Bando Y., Onuki R., Katayama T., Manabe T., Kudo T., Taira K., Tohyama M. (2005) Double-strand RNA dependent protein kinase (PKR) is involved in the extrastriatal degeneration in Parkinson's disease and Huntington's disease. Neurochem. Int. 46, 11-8. 
Bandopadhyay R., Kingsbury A. E., Cookson M. R., Reid A. R., Evans I. M., Hope A. D., Pittman A. M., et al. (2004) The expression of DJ-1 (PARK7) in normal human CNS and idiopathic Parkinson's disease. Brain 127, 420-30.

Banerjee C., Nyengaard J. R., Wevers A., Vos R. a de, Jansen Steur E. N., Lindstrom J., Pilz K., Nowacki S., Bloch W., Schröder H. (2000) Cellular expression of alpha7 nicotinic acetylcholine receptor protein in the temporal cortex in Alzheimer's and Parkinson's disease-a stereological approach. Neurobiol. Dis. 7, 666-72.

Barrachina M., Castaño E., Dalfó E., Maes T., Buesa C., Ferrer I. (2006) Reduced ubiquitin Cterminal hydrolase-1 expression levels in dementia with Lewy bodies. Neurobiol. Dis. 22, 26573.

Beach T. G., Adler C. H., Sue L. I., Peirce J. B., Bachalakuri J., Dalsing-Hernandez J. E., Lue L. F., et al. (2008) Reduced striatal tyrosine hydroxylase in incidental Lewy body disease. Acta Neuropathol. 115, 445-51.

Bellinger F. P., Raman A. V, Rueli R. H., Bellinger M. T., Dewing A. S., Seale L. A., Andres M. A., et al. (2012) Changes in selenoprotein P in substantia nigra and putamen in Parkinson's disease. J. Parkinsons. Dis. 2, 115-26.

Bender A., Desplats P., Spencer B., Rockenstein E., Adame A., Elstner M., Laub C., et al. (2013) TOM40 mediates mitochondrial dysfunction induced by $\alpha$-synuclein accumulation in Parkinson's disease. PLoS One 8, e62277.

Bender A., Krishnan K. J., Morris C. M., Taylor G. a, Reeve A. K., Perry R. H., Jaros E., et al. (2006) High levels of mitochondrial DNA deletions in substantia nigra neurons in aging and Parkinson disease. Nat. Genet. 38, 515-7.

Betarbet R., Anderson L. R., Gearing M., Hodges T. R., Fritz J. J., Lah J. J., Levey A. I. (2008) Fasassociated factor 1 and Parkinson's disease. Neurobiol. Dis. 31, 309-15.

Braak H., Braak E. (2000) Pathoanatomy of Parkinson's disease. J. Neurol. 247, II3-I10.

Braak H., Rüb U., Gai W. P., Tredici K. Del (2003) Idiopathic Parkinson's disease: Possible routes by which vulnerable neuronal types may be subject to neuroinvasion by an unknown pathogen. $J$. Neural Transm. 110, 517-536.

Brochard V., Combadière B., Prigent A., Laouar Y., Perrin A., Beray-Berthat V., Bonduelle O., et al. (2009) Infiltration of CD4+ lymphocytes into the brain contributes to neurodegeneration in a mouse model of Parkinson disease. J. Clin. Invest. 119, 182-92.

Bukhatwa S., Zeng B.-Y., Rose S., Jenner P. (2010) A comparison of changes in proteasomal subunit expression in the substantia nigra in Parkinson's disease, multiple system atrophy and progressive supranuclear palsy. Brain Res. 1326, 174-83.

Burghaus L., Schütz U., Krempel U., Lindstrom J., Schröder H. (2003) Loss of nicotinic acetylcholine receptor subunits $\alpha 4$ and $\alpha 7$ in the cerebral cortex of Parkinson patients. Parkinsonism Relat. Disord. 9, 243-246.

Burguillos M. a, Deierborg T., Kavanagh E., Persson A., Hajji N., Garcia-Quintanilla A., Cano J., et al. (2011) Caspase signalling controls microglia activation and neurotoxicity. Nature 472, 319 24.

Büttner S., Habernig L., Broeskamp F., Ruli D., Vögtle F. N., Vlachos M., Macchi F., et al. (2013) Endonuclease $\mathrm{G}$ mediates $\alpha$-synuclein cytotoxicity during Parkinson's disease. EMBO J. 32, 3041-3054.

Camins A., Pizarro J. G., Alvira D., Gutierrez-Cuesta J., la Torre A. V. de, Folch J., Sureda F. X., et al. (2010) Activation of ataxia telangiectasia muted under experimental models and human 
Parkinson's disease. Cell. Mol. Life Sci. 67, 3865-82.

Caraveo G., Auluck P. K., Whitesell L., Chung C. Y., Baru V., Mosharov E. V, Yan X., et al. (2014) Calcineurin determines toxic versus beneficial responses to $\alpha$-synuclein. Proc. Natl. Acad. Sci. U. S. A. 111, E3544-52.

Cargnello M., Roux P. P. (2011) Activation and function of the MAPKs and their substrates, the MAPK-activated protein kinases. Microbiol. Mol. Biol. Rev. 75, 50-83.

Chaudhuri K. R., Healy D. G., Schapira A. H. V (2006) Non-motor symptoms of Parkinson's disease: diagnosis and management. Lancet. Neurol. 5, 235-45.

Chauhan A., Jeans A. F. (2015) Is Parkinson's disease truly a prion-like disorder? An appraisal of current evidence. Neurol. Res. Int. 2015, 345285.

Chauhan N. B., Siegel G. J., Lee J. M. (2001) Depletion of glial cell line-derived neurotrophic factor in substantia nigra neurons of Parkinson's disease brain. J. Chem. Neuroanat. 21, 277-288.

Cho H. J., Liu G., Jin S. M., Parisiadou L., Xie C., Yu J., Sun L., et al. (2013) MicroRNA-205 regulates the expression of Parkinson's disease-related leucine-rich repeat kinase 2 protein. Hum. Mol. Genet. 22, 608-20.

Choi D.-H., Cristóvão A. C., Guhathakurta S., Lee J., Joh T. H., Beal M. F., Kim Y.-S. (2012) NADPH Oxidase 1-Mediated Oxidative Stress Leads to Dopamine Neuron Death in Parkinson's Disease. Antioxid. Redox Signal. 16, 1033-1045.

Choi D.-H., Kim Y.-J., Kim Y.-G., Joh T. H., Beal M. F., Kim Y.-S. (2011) Role of matrix metalloproteinase 3-mediated alpha-synuclein cleavage in dopaminergic cell death. J. Biol. Chem. 286, 14168-77.

Choi D.-K., Pennathur S., Perier C., Tieu K., Teismann P., Wu D.-C., Jackson-Lewis V., et al. (2005a) Ablation of the inflammatory enzyme myeloperoxidase mitigates features of Parkinson's disease in mice. J. Neurosci. 25, 6594-600.

Choi J., Rees H. D., Weintraub S. T., Levey A. I., Chin L.-S., Li L. (2005b) Oxidative modifications and aggregation of $\mathrm{Cu}, \mathrm{Zn}$-superoxide dismutase associated with Alzheimer and Parkinson diseases. J. Biol. Chem. 280, 11648-55.

Choi M. S., Nakamura T., Cho S.-J., Han X., Holland E. a, Qu J., Petsko G. a, Yates J. R., Liddington R. C., Lipton S. a (2014) Transnitrosylation from DJ-1 to PTEN attenuates neuronal cell death in parkinson's disease models. J. Neurosci. 34, 15123-31.

Chu Y., Dodiya H., Aebischer P., Olanow C. W., Kordower J. H. (2009) Alterations in lysosomal and proteasomal markers in Parkinson's disease: relationship to alpha-synuclein inclusions. Neurobiol. Dis. 35, 385-98.

Chu Y., Goldman J. G., Kelly L., He Y., Waliczek T., Kordower J. H. (2014) Abnormal alphasynuclein reduces nigral voltage-dependent anion channel 1 in sporadic and experimental Parkinson's disease. Neurobiol. Dis. 69, 1-14.

Chu Y., Le W., Kompoliti K., Jankovic J., Mufson E. J., Kordower J. H. (2006) Nurr1 in Parkinson's disease and related disorders. J. Comp. Neurol. 494, 495-514.

Chu Y., Mickiewicz A. L., Kordower J. H. (2011) $\alpha$-synuclein aggregation reduces nigral myocyte enhancer factor-2D in idiopathic and experimental Parkinson's disease. Neurobiol. Dis. 41, 7182.

Chung K. K. K., Thomas B., Li X., Pletnikova O., Troncoso J. C., Marsh L., Dawson V. L., Dawson T. M. (2004) S-nitrosylation of parkin regulates ubiquitination and compromises parkin's protective function. Science 304, 1328-1331. 
Citron B. A., Suo Z., SantaCruz K., Davies P. J. A., Qin F., Festoff B. W. (2002) Protein crosslinking, tissue transglutaminase, alternative splicing and neurodegeneration, in Neurochem. Int., Vol. 40, pp. 69-78.

Cooper-Knock J., Kirby J., Ferraiuolo L., Heath P. R., Rattray M., Shaw P. J. (2012) Gene expression profiling in human neurodegenerative disease. Nat. Rev. Neurol. 8, 518-530.

Court J. A., Piggott M. A., Lloyd S., Cookson N., Ballard C. G., McKeith I. G., Perry R. H., Perry E. K. (2000) Nicotine binding in human striatum: Elevation in schizophrenia and reductions in dementia with Lewy bodies, Parkinson's disease and Alzheimer's disease and in relation to neuroleptic medication. Neuroscience 98, 79-87.

D'Andrea M. R., Ilyin S., Plata-Salaman C. R. (2001) Abnormal patterns of microtubule-associated protein-2 (MAP-2) immunolabeling in neuronal nuclei and Lewy bodies in Parkinson's disease substantia nigra brain tissues. Neurosci. Lett. 306, 137-140.

Dalfó E., Portero-Otín M., Ayala V., Martínez A., Pamplona R., Ferrer I. (2005) Evidence of oxidative stress in the neocortex in incidental Lewy body disease. J. Neuropathol. Exp. Neurol. 64, 81630.

Davies K. M., Bohic S., Carmona A., Ortega R., Cottam V., Hare D. J., Finberg J. P. M. M., et al. (2014) Copper pathology in vulnerable brain regions in Parkinson's disease. Neurobiol. Aging 35, 858-866.

Dawson T. M., Dawson V. L. (2010) The role of parkin in familial and sporadic Parkinson's disease. Mov. Disord. 25, 32-39.

Decressac M., Kadkhodaei B., Mattsson B., Laguna A., Perlmann T., Björklund A. (2012) $\alpha$ Synuclein-induced down-regulation of Nurr1 disrupts GDNF signaling in nigral dopamine neurons. Sci. Transl. Med. 4, 156-63.

Decressac M., Mattsson B., Weikop P., Lundblad M., Jakobsson J., Björklund A. (2013) TFEBmediated autophagy rescues midbrain dopamine neurons from $\alpha$-synuclein toxicity. Proc. Natl. Acad. Sci. U. S. A. 110, E1817-26.

Dehay B., Bové J., Rodríguez-Muela N., Perier C., Recasens A., Boya P., Vila M. (2010) Pathogenic lysosomal depletion in Parkinson's disease. J. Neurosci. 30, 12535-44.

Dehay B., Ramirez A., Martinez-Vicente M., Perier C., Canron M.-H. M.-H., Doudnikoff E., Vital A., Vila M., Klein C., Bezard E. (2012) Loss of P-type ATPase ATP13A2/PARK9 function induces general lysosomal deficiency and leads to Parkinson disease neurodegeneration. Proc. Natl. Acad. Sci. 109, 9611-9616.

DelleDonne A., Klos K. J., Fujishiro H., Ahmed Z., Parisi J. E., Josephs K. A., Frigerio R., et al. (2008) Incidental Lewy body disease and preclinical Parkinson disease. Arch. Neurol. 65, 107480.

Depboylu C., Höllerhage M., Schnurrbusch S., Brundin P., Oertel W. H., Schrattenholz A., Höglinger G. U. (2012) Neuregulin-1 receptor tyrosine kinase ErbB4 is upregulated in midbrain dopaminergic neurons in Parkinson disease. Neurosci. Lett. 531, 209-14.

Depboylu C., Schäfer M. K.-H., Arias-Carrión O., Oertel W. H., Weihe E., Höglinger G. U. (2011) Possible involvement of complement factor $\mathrm{Clq}$ in the clearance of extracellular neuromelanin from the substantia nigra in Parkinson disease. J. Neuropathol. Exp. Neurol. 70, 125-132.

Desplats P., Spencer B., Coffee E., Patel P., Michael S., Patrick C., Adame A., Rockenstein E., Masliah E. (2011) Alpha-synuclein sequesters Dnmt1 from the nucleus: a novel mechanism for epigenetic alterations in Lewy body diseases. J. Biol. Chem. 286, 9031-7.

Devi L., Raghavendran V., Prabhu B. M., Avadhani N. G., Anandatheerthavarada H. K. (2008) 
Mitochondrial import and accumulation of alpha-synuclein impair complex I in human dopaminergic neuronal cultures and Parkinson disease brain. J. Biol. Chem. 283, 9089-9100.

Dexter D. T., Sian J., Rose S., Hindmarsh J. G., Mann V. M., Cooper J. M., Wells F. R., Daniel S. E., Lees A. J., Schapira A. H. (1994) Indices of oxidative stress and mitochondrial function in individuals with incidental Lewy body disease. Ann. Neurol. 35, 38-44.

Dexter D. T., Wells F. R., Lees A. J., Agid F., Agid Y., Jenner P., Marsden C. D. (1989) Increased nigral iron content and alterations in other metal ions occurring in brain in Parkinson's disease. $J$. Neurochem. 52, 1830-1836.

Dickson D. W., Fujishiro H., DelleDonne A., Menke J., Ahmed Z., Klos K. J., Josephs K. A., et al. (2008) Evidence that incidental Lewy body disease is pre-symptomatic Parkinson's disease. Acta Neuropathol. 115, 437-44.

Dijkstra A. A., Voorn P., Berendse H. W., Groenewegen H. J., Rozemuller A. J. M., Berg W. D. J. van de (2014) Stage-dependent nigral neuronal loss in incidental Lewy body and Parkinson's disease. Mov. Disord. 29, 1244-51.

Doorn K. J., Moors T., Drukarch B., Berg W. D. van de, Lucassen P. J., Dam A.-M. van (2014) Microglial phenotypes and toll-like receptor 2 in the substantia nigra and hippocampus of incidental Lewy body disease cases and Parkinson's disease patients. Acta Neuropathol. Commun. 2, 90.

Driver-Dunckley E., Adler C. H., Hentz J. G., Dugger B. N., Shill H. A., Caviness J. N., Sabbagh M. N., Beach T. G. (2014) Olfactory dysfunction in incidental Lewy body disease and Parkinson's disease. Parkinsonism Relat. Disord. 20, 1260-2.

Du Y., Wooten M. C., Wooten M. W. (2009) Oxidative damage to the promoter region of SQSTM1/p62 is common to neurodegenerative disease. Neurobiol. Dis. 35, 302-10.

Duerson K., Woltjer R. L., Mookherjee P., Leverenz J. B., Montine T. J., Bird T. D., Pow D. V., Rauen T., Cook D. G. (2009) Detergent-insoluble EAAC1/EAAT3 aberrantly accumulates in hippocampal neurons of Alzheimer's disease patients. Brain Pathol. 19, 267-278.

Dufty B. M., Warner L. R., Hou S. T., Jiang S. X., Gomez-Isla T., Leenhouts K. M., Oxford J. T., Feany M. B., Masliah E., Rohn T. T. (2007) Calpain-cleavage of alpha-synuclein: connecting proteolytic processing to disease-linked aggregation. Am. J. Pathol. 170, 1725-38.

Duka V., Lee J.-H., Credle J., Wills J., Oaks A., Smolinsky C., Shah K., Mash D. C., Masliah E., Sidhu A. (2013) Identification of the sites of tau hyperphosphorylation and activation of tau kinases in synucleinopathies and Alzheimer's diseases. PLoS One 8, e75025.

Dunn L., Allen G. F. G., Mamais A., Ling H., Li A., Duberley K. E., Hargreaves I. P., et al. (2014) Dysregulation of glucose metabolism is an early event in sporadic Parkinson's disease. Neurobiol. Aging 35, 1111-1115.

Duty S., Jenner P. (2011) Animal models of Parkinson's disease: a source of novel treatments and clues to the cause of the disease. Br. J. Pharmacol. 164, 1357-91.

Elmore S. (2007) Apoptosis: a review of programmed cell death. Toxicol Pathol 35, 495-516.

Eschbach J., Einem B. von, Müller K., Bayer H., Scheffold A., Morrison B. E., Rudolph K. L., et al. (2015) Mutual exacerbation of peroxisome proliferator-activated receptor $\gamma$ coactivator $1 \alpha$ deregulation and $\alpha$-synuclein oligomerization. Ann. Neurol. 77, 15-32.

Fang J., Nakamura T., Cho D., Gu Z., Lipton S. A. (2007) S-nitrosylation of peroxiredoxin 2 promotes oxidative stress-induced neuronal cell death in Parkinson's disease. Proc. Natl. Acad. Sci. U. S. A. 104, 18742-18747. 
Faucheux B. A., Hauw J.-J., Agid Y., Hirsch E. C. (1997) The density of 125-transferrin binding sites on perikarya of melanized neurons of the subtantia nigra is decreased in Parkinson's disease. Brain Res 749, 170-174.

Faucheux B. A., Nillesse N., Damier P., Spik G., Mouatt-Prigent A., Pierce A., Leveugle B., Kubis N., Hauw J. J., Agid Y. (1995) Expression of lactoferrin receptors is increased in the mesencephalon of patients with Parkinson disease. Proc. Natl. Acad. Sci. U. S. A. 92, 9603-9607.

Ferrer I., Blanco R. (2000) N-myc and c-myc expression in Alzheimer disease, Huntington disease and Parkinson disease. Mol. Brain Res. 77, 270-276.

Ferrer I., Blanco R., Cutillas B., Ambrosio S. (2000) Fas and Fas-L expression in Huntington's disease and Parkinson's disease. Neuropathol. Appl. Neurobiol. 26, 424-433.

Ferrer I., Gómez A., Carmona M., Huesa G., Porta S., Riera-Codina M., Biagioli M., Gustincich S., Aso E. (2011) Neuronal hemoglobin is reduced in Alzheimer's disease, argyrophilic grain disease, Parkinson's disease, and Dementia with Lewy bodies. J. Alzheimer's Dis. 23, 537-550.

Ferrer I., Martinez A., Boluda S., Parchi P., Barrachina M. (2008) Brain banks: Benefits, limitations and cautions concerning the use of post-mortem brain tissue for molecular studies. Cell Tissue Bank. 9, 181-194.

Ferrer I., Perez E., Dalfó E., Barrachina M. (2007) Abnormal levels of prohibitin and ATP synthase in the substantia nigra and frontal cortex in Parkinson's disease. Neurosci. Lett. 415, 205-9.

Folch J., Junyent F., Verdaguer E., Auladell C., Pizarro J. G., Beas-Zarate C., Pallàs M., Camins A. (2012) Role of cell cycle re-entry in neurons: A common apoptotic mechanism of neuronal cell death. Neurotox. Res. 22, 195-207.

Fukae J., Sato S., Shiba K., Sato K., Mori H., Sharp P. a, Mizuno Y., Hattori N. (2009) Programmed cell death- 2 isoform 1 is ubiquitinated by parkin and increased in the substantia nigra of patients with autosomal recessive Parkinson's disease. FEBS Lett. 583, 521-5.

Fukae J., Takanashi M., Kubo S., Nishioka K., Nakabeppu Y., Mori H., Mizuno Y., Hattori N. (2005) Expression of 8-oxoguanine DNA glycosylase (OGG1) in Parkinson's disease and related neurodegenerative disorders. Acta Neuropathol. 109, 256-62.

Galazka-Friedman J., Bauminger E. R., Koziorowski D., Friedman A. (2004) Mössbauer spectroscopy and ELISA studies reveal differences between Parkinson's disease and control substantia nigra. Biochim. Biophys. Acta - Mol. Basis Dis. 1688, 130-136.

Gao L., She H., Li W., Zeng J., Zhu J., Jones D. P., Mao Z., Gao G., Yang Q. (2014) Oxidation of Survival Factor MEF2D in Neuronal Death and Parkinson's Disease. Antioxid. Redox Signal. 20, 2936-2949.

Garcia-Reitböck P., Anichtchik O., Bellucci A., Iovino M., Ballini C., Fineberg E., Ghetti B., et al. (2010) SNARE protein redistribution and synaptic failure in a transgenic mouse model of Parkinson's disease. Brain 133, 2032-44.

Gargalidis-Moudanos C., Pizzinat N., Javoy-Agid F., Remaury A., Parini A. (1997) I2-imidazoline binding sites and monoamine oxidase activity in human postmortem brain from patients with Parkinson's disease. Neurochem. Int.

Gegg M. E., Burke D., Heales S. J. R., Cooper J. M., Hardy J., Wood N. W., Schapira A. H. V (2012) Glucocerebrosidase deficiency in substantia nigra of parkinson disease brains. Ann. Neurol. 72, 455-63.

Gerlach M., Gsell W., Kornhuber J., Jellinger K., Krieger V., Pantucek F., Vock R., Riederer P. (1996) A post mortem study on neurochemical markers of dopaminergic, GABA-ergic and glutamatergic neurons in basal ganglia-thalamocortical circuits in Parkinson syndrome. Brain 
Res 741, 142-152.

Ghosh A., Roy A., Matras J., Brahmachari S., Gendelman H. E., Pahan K. (2009) Simvastatin inhibits the activation of p21ras and prevents the loss of dopaminergic neurons in a mouse model of Parkinson's disease. J. Neurosci. 29, 13543-56.

Giasson B. I., Duda J. E., Murray I. V, Chen Q., Souza J. M., Hurtig H. I., Ischiropoulos H., Trojanowski J. Q., Lee V. M. (2000) Oxidative damage linked to neurodegeneration by selective alpha-synuclein nitration in synucleinopathy lesions. Science 290, 985-989.

Goedert M., Falcon B., Clavaguera F., Tolnay M. (2014) Prion-like mechanisms in the pathogenesis of tauopathies and synucleinopathies. Curr. Neurol. Neurosci. Rep. 14, 495.

Good P. F., Olanow C. W., Perl D. P. (1992) Neuromelanin-containing neurons of the substantia nigra accumulate iron and aluminum in Parkinson's disease: a LAMMA study. Brain Res. 593, 343-6.

Goodchild R. E., Court J. A., Hobson I., Piggott M. A., Perry R. H., Ince P., Jaros E., Perry E. K. (1999) Distribution of histamine H3-receptor binding in the normal human basal ganglia: comparison with Huntington's and Parkinson's disease cases. Eur. J. Neurosci. 11, 449-56.

Gotti C., Moretti M., Bohr I., Ziabreva I., Vailati S., Longhi R., Riganti L., et al. (2006) Selective nicotinic acetylcholine receptor subunit deficits identified in Alzheimer's disease, Parkinson's disease and dementia with Lewy bodies by immunoprecipitation. Neurobiol. Dis. 23, 481-9.

Griffiths P. D., Perry R. H., Crossman A. R. (1994) A detailed anatomical analysis of neurotransmitter receptors in the putamen and caudate in Parkinson's disease and Alzheimer's disease. Neurosci. Lett. 169, 68-72.

Griffiths P. D., Sambrook M. A., Perry R., Crossman A. R. (1990) Changes in benzodiazepine and acetylcholine receptors in the globus pallidus in Parkinson's disease. J. Neurol. Sci. 100, 131136.

Guerreiro P. S., Huang Y., Gysbers A., Cheng D., Gai W. P., Outeiro T. F., Halliday G. M. (2013) LRRK2 interactions with $\alpha$-synuclein in Parkinson's disease brains and in cell models. J. Mol. Med. 91, 513-22.

Güzey C., Allard P., Brännström T., Spigset O. (2012) Radioligand binding to brain dopamine and serotonin receptors and transporters in Parkinson's disease: relation to gene polymorphisms. Int. J. Neurosci. 122, 124-32.

Halliday G. M., Ophof A., Broe M., Jensen P. H., Kettle E., Fedorow H., Cartwright M. I., Griffiths F. M., Shepherd C. E., Double K. L. (2005) Alpha-synuclein redistributes to neuromelanin lipid in the substantia nigra early in Parkinson's disease. Brain 128, 2654-64.

Halliday G. M., Stevens C. H. (2011) Glia: initiators and progressors of pathology in Parkinson's disease. Mov. Disord. 26, 6-17.

Halliday G. M., Tredici K. Del, Braak H. (2006) Critical appraisal of brain pathology staging related to presymptomatic and symptomatic cases of sporadic Parkinson's disease. J. Neural Transm. Suppl. 70, 99-103.

Hamdane M., Bretteville A., Sambo A.-V., Schindowski K., Bégard S., Delacourte A., Bertrand P., Buée L. (2005) p25/Cdk5-mediated retinoblastoma phosphorylation is an early event in neuronal cell death. J. Cell Sci. 118, 1291-8.

Hartmann A., Hunot S., Michel P. P., Muriel M. P., Vyas S., Faucheux B. A., Mouatt-Prigent A., et al. (2000) Caspase-3: A vulnerability factor and final effector in apoptotic death of dopaminergic neurons in Parkinson's disease. Proc. Natl. Acad. Sci. U. S. A. 97, 2875-80.

Hartmann A., Michel P. P., Troadec J. D., Mouatt-Prigent A., Faucheux B. A., Ruberg M., Agid Y., 
Hirsch E. C. (2001a) Is bax a mitochondrial mediator in apoptotic death of dopaminergic neurons in Parkinson's disease? J. Neurochem. 76, 1785-1793.

Hartmann A., Mouatt-Prigent A., Faucheux B. A., Agid Y., Hirsch E. C. (2002) FADD: A link between TNF family receptors and caspases in Parkinson's disease. Neurology 58, 308-10.

Hartmann A., Troadec J. D., Hunot S., Kikly K., Faucheux B. A., Mouatt-Prigent A., Ruberg M., Agid Y., Hirsch E. C. (2001b) Caspase-8 is an effector in apoptotic death of dopaminergic neurons in Parkinson's disease, but pathway inhibition results in neuronal necrosis. J. Neurosci. 21, 22472255.

Hashioka S., Klegeris A., Schwab C., McGeer P. L. (2009) Interferon-gamma-dependent cytotoxic activation of human astrocytes and astrocytoma cells. Neurobiol. Aging 30, 1924-35.

Haskin J., Szargel R., Shani V., Mekies L. N., Rott R., Lim G. G. Y., Lim K.-L., Bandopadhyay R., Wolosker H., Engelender S. (2013) AF-6 is a positive modulator of the PINK1/parkin pathway and is deficient in Parkinson's disease. Hum. Mol. Genet. 22, 2083-96.

Hattingen E., Magerkurth J., Pilatus U., Mozer A., Seifried C., Steinmetz H., Zanella F., Hilker R. (2009) Phosphorus and proton magnetic resonance spectroscopy demonstrates mitochondrial dysfunction in early and advanced Parkinson's disease. Brain 132, 3285-97.

Hattori N., Ikebe S., Tanaka M., Ozawa T., Mizuno Y. (1993) Immunohistochemical studies on complexes I, II, III, and IV of mitochondria in Parkinson's disease. Adv. Neurol.

Henderson-Smith A., Chow D., Meechoovet B., Aziz M., Jacobson S. a, Shill H. a, Sabbagh M. N., et al. (2013) SMG1 identified as a regulator of Parkinson's disease-associated alpha-synuclein through siRNA screening. PLoS One 8, e77711.

Hirsch E. C., Brandel J.-P. P., Galle P., Javoy-Agid F., Agid Y. (1991) Iron and aluminum increase in the substantia nigra of patients with Parkinson's disease: an X-ray microanalysis. J. Neurochem. 56, 446-51.

Hirsch E. C., Graybiel A. M., Duyckaerts C., Javoy-Agid F. (1987) Neuronal loss in the pedunculopontine tegmental nucleus in Parkinson disease and in progressive supranuclear palsy. Proc. Natl. Acad. Sci. U. S. A. 84, 5976-80.

Höglinger G. U., Rizk P., Muriel M. P., Duyckaerts C., Oertel W. H., Caille I., Hirsch E. C. (2004) Dopamine depletion impairs precursor cell proliferation in Parkinson disease. Nat. Neurosci. 7 , 726-35.

Hoogendijk W. J. G., Purba J. S., Hofman M. A., Vos R. A. I. De, Jansen E. N. H., Swaab D. F. (1998) Depression in Parkinson's disease is not accompanied by more corticotropin-releasing hormone expressing neurons in the hypothalamic paraventricular nucleus. Biol. Psychiatry 43, 913-917.

Hoozemans J. J. M., Haastert E. S. van, Eikelenboom P., Vos R. a I. de, Rozemuller J. M., Scheper W. (2007) Activation of the unfolded protein response in Parkinson's disease. Biochem. Biophys. Res. Commun. 354, 707-11.

Hoozemans J. J. M., Haastert E. S. van, Nijholt D. a T., Rozemuller A. J. M., Scheper W. (2012) Activation of the unfolded protein response is an early event in Alzheimer's and Parkinson's disease. Neurodegener. Dis. 10, 212-5.

Howitt J., Gysbers A. M., Ayton S., Carew-Jones F., Putz U., Finkelstein D. I., Halliday G. M., Tan S.-S. (2014) Increased Ndfip1 in the substantia nigra of Parkinsonian brains is associated with elevated iron levels. PLoS One 9, e87119.

Hu X., Weng Z., Chu C. T., Zhang L., Cao G., Gao Y., Signore A., et al. (2011) Peroxiredoxin-2 protects against 6-hydroxydopamine-induced dopaminergic neurodegeneration via attenuation of 
the apoptosis signal-regulating kinase (ASK1) signaling cascade. J. Neurosci. 31, 247-61.

Hunot S., Boissière F., Faucheux B., Brugg B., Mouatt-Prigent A., Agid Y., Hirsch E. C. C. (1996) Nitric oxide synthase and neuronal vulnerability in Parkinson's disease. Neuroscience 72, 355363.

Hunot S., Brugg B., Ricard D., Michel P. P., Muriel M. P., Ruberg M., Faucheux B. A., Agid Y., Hirsch E. C. (1997) Nuclear translocation of NF-kappaB is increased in dopaminergic neurons of patients with Parkinson disease. Proc. Natl. Acad. Sci. U. S. A. 94, 7531-7536.

Hunot S., Dugas N., Faucheux B., Hartmann A., Tardieu M., Debré P., Agid Y., Dugas B., Hirsch E. C. (1999) FcepsilonRII/CD23 is expressed in Parkinson's disease and induces, in vitro, production of nitric oxide and tumor necrosis factor-alpha in glial cells. J. Neurosci. 19, 3440-7.

Hunot S., Vila M., Teismann P., Davis R. J., Hirsch E. C., Przedborski S., Rakic P., Flavell R. A. (2004) JNK-mediated induction of cyclooxygenase 2 is required for neurodegeneration in a mouse model of Parkinson's disease. Proc. Natl. Acad. Sci. U. S. A. 101, 665-670.

Hurley M. J., Brandon B., Gentleman S. M., Dexter D. T. (2013) Parkinson's disease is associated with altered expression of $\mathrm{CaV} 1$ channels and calcium-binding proteins. Brain 136, 2077-97.

Iacono D., Geraci-Erck M., Rabin M. L., Adler C. H., Serrano G., Beach T. G., Kurlan R. (2015) Parkinson disease and incidental Lewy body disease: Just a question of time? Neurology 85, 1670-9.

Iczkiewicz J., Jackson M. J., Smith L. a, Rose S., Jenner P. (2006) Osteopontin expression in substantia nigra in MPTP-treated primates and in Parkinson's disease. Brain Res. 1118, 239-50.

Imam S. Z., Zhou Q., Yamamoto A., Valente A. J., Ali S. F., Bains M., Roberts J. L., Kahle P. J., Clark R. a, Li S. (2011) Novel regulation of parkin function through c-Abl-mediated tyrosine phosphorylation: implications for Parkinson's disease. J. Neurosci. 31, 157-63.

Imamura K., Hishikawa N., Ono K., Suzuki H., Sawada M., Nagatsu T., Yoshida M., Hashizume Y. (2005) Cytokine production of activated microglia and decrease in neurotrophic factors of neurons in the hippocampus of Lewy body disease brains. Acta Neuropathol. 109, 141-50.

Imamura K., Hishikawa N., Sawada M., Nagatsu T., Yoshida M., Hashizume Y. (2003) Distribution of major histocompatibility complex class II-positive microglia and cytokine profile of Parkinson's disease brains. Acta Neuropathol. 106, 518-26.

Itoh K., Weis S., Mehraein P., Müller-Höcker J. (1997) Defects of cytochrome c oxidase in the substantia nigra of Parkinson's disease: An immunohistochemical and morphometric study. Mov. Disord. 12, 9-16.

Iwakura Y., Piao Y.-S., Mizuno M., Takei N., Kakita A., Takahashi H., Nawa H. (2005) Influences of dopaminergic lesion on epidermal growth factor-ErbB signals in Parkinson's disease and its model: neurotrophic implication in nigrostriatal neurons. J. Neurochem. 93, 974-83.

Jellinger K., Kienzl E., Rumpelmair G., Riederer P., Stachelberger H., Ben-Shachar D., Youdim M. B. (1992) Iron-melanin complex in substantia nigra of parkinsonian brains: an X-ray microanalysis. J. Neurochem. 59, 1168-1171.

Jiang H., He P., Adler C. H., Shill H., Beach T. G., Li R., Shen Y. (2012) Bid signal pathway components are identified in the temporal cortex with Parkinson disease. Neurology 79, 176773.

Jordan-Sciutto K. L., Dorsey R., Chalovich E. M., Hammond R. R., Achim C. L. (2003) Expression patterns of retinoblastoma protein in Parkinson disease. J. Neuropathol. Exp. Neurol. 62, 68-74.

Kastner A., Hirsch E. C., Agid Y., Javoy-Agid F. (1993) Tyrosine hydroxylase protein and messenger 
RNA in the dopaminergic nigral neurons of patients with Parkinson's disease. Brain Res. 606, 341-345.

Kaushik S., Cuervo A. M. (2012) Chaperone-mediated autophagy: a unique way to enter the lysosome world. Trends Cell Biol. 22, 407-17.

Kawamoto Y., Ito H., Ayaki T., Takahashi R. (2014) Immunohistochemical localization of apoptosome-related proteins in Lewy bodies in Parkinson's disease and dementia with Lewy bodies. Brain Res. 1571, 39-48.

Keeney P. M., Xie J., Capaldi R. a, Bennett J. P. (2006) Parkinson's disease brain mitochondrial complex I has oxidatively damaged subunits and is functionally impaired and misassembled. $J$. Neurosci. 26, 5256-64.

Kinugawa K., Monnet Y., Lu L., Bekaert A. J., Théry C., Mallat Z., Hirsch E. C., Hunot S. (2013) MFGE8 does not orchestrate clearance of apoptotic neurons in a mouse model of Parkinson's disease. Neurobiol. Dis. 51, 192-201.

Knott C., Stern G., Kingsbury A., Welcher A. A., Wilkin G. P. (2002) Elevated glial brain-derived neurotrophic factor in Parkinson's diseased nigra. Park. Relat. Disord. 8, 329-341.

Knott C., Stern G., Wilkin G. P. (2000) Inflammatory regulators in Parkinson's disease: iNOS, lipocortin-1, and cyclooxygenases-1 and -2. Mol. Cell. Neurosci. 16, 724-39.

Ko H. S., Kim S. W., Sriram S. R., Dawson V. L., Dawson T. M. (2006) Identification of far upstream element-binding protein-1 as an authentic Parkin substrate. J. Biol. Chem. 281, 16193-6.

Ko H. S., Lee Y., Shin J.-H., Karuppagounder S. S., Gadad B. S., Koleske A. J., Pletnikova O., Troncoso J. C., Dawson V. L., Dawson T. M. (2010) Phosphorylation by the c-Abl protein tyrosine kinase inhibits parkin's ubiquitination and protective function. Proc. Natl. Acad. Sci. U. S. A. 107, 16691-16696.

Korolchuk V. I., Menzies F. M., Rubinsztein D. C. (2010) Mechanisms of cross-talk between the ubiquitin-proteasome and autophagy-lysosome systems. FEBS Lett. 584, 1393-1398.

Korutla L., Furlong H., Mackler S. (2014) NAC1, A POZ/BTB protein interacts with Parkin and may contribute to Parkinson's disease. Neuroscience 257, 86-95.

Koziorowski D., Friedman A., Arosio P., Santambrogio P., Dziewulska D. (2007) ELISA reveals a difference in the structure of substantia nigra ferritin in Parkinson's disease and incidental Lewy body compared to control. Parkinsonism Relat. Disord. 13, 214-8.

Kurup P. K., Xu J., Videira R. A., Ononenyi C., Baltazar G., Lombroso P. J., Nairn A. C. (2015) STEP61 is a substrate of the E3 ligase parkin and is upregulated in Parkinson's disease. Proc. Natl. Acad. Sci. U. S. A. 112, 1202-7.

Laguna A., Schintu N., Nobre A., Alvarsson A., Volakakis N., Jacobsen J. K., Gómez-Galán M., et al. (2015) Dopaminergic control of autophagic-lysosomal function implicates Lmx1b in Parkinson's disease. Nat. Neurosci. 18.

Lastres-Becker I., Ulusoy A., Innamorato N. G., Sahin G., Rábano A., Kirik D., Cuadrado A. (2012) $\alpha$-Synuclein expression and Nrf2 deficiency cooperate to aggravate protein aggregation, neuronal death and inflammation in early-stage Parkinson's disease. Hum. Mol. Genet. 21, 3173-92.

LaVoie M. J., Ostaszewski B. L., Weihofen A., Schlossmacher M. G., Selkoe D. J. (2005) Dopamine covalently modifies and functionally inactivates parkin. Nat. Med. 11, 1214-21.

Leake A., Perry E. K., Perry R. H., Jabeen S., Fairbairn A. F., McKeith I. G., Ferrier I. N. (1991) Neocortical concentrations of neuropeptides in senile dementia of the Alzheimer and Lewy body type: Comparison with Parkinson's disease and severity correlations. Biol. Psychiatry 29, 357 
364.

Lee Y. Y.-I., Karuppagounder S. S., Shin J.-H., Lee Y. Y.-I., Ko H. S., Swing D., Jiang H., et al. (2013) Parthanatos mediates AIMP2-activated age-dependent dopaminergic neuronal loss. Nat. Neurosci. 16, 1392-400.

Letters E. N., Mogi M., Harada M., Kondo T., Mizuno Y., Narabayashi H., Riederer P., Nagatsu T. (1996) bcl-2 protein is increased in the brain from parkinsonian patients. Neurosci. Lett. 215, $137-139$.

Leveugle B., Faucheux B. A., Bouras C., Nillesse N., Spik G., Hirsch E. C., Agid Y., Hof P. R. (1996) Cellular distribution of the iron-binding protein lactotransferrin in the mesencephalon of Parkinson's disease cases. Acta Neuropathol. 91, 566-72.

Li J.-Y., Englund E., Holton J. L., Soulet D., Hagell P., Lees A. J., Lashley T., et al. (2008) Lewy bodies in grafted neurons in subjects with Parkinson's disease suggest host-to-graft disease propagation. Nat. Med. 14, 501-503.

Lin M. T., Cantuti-castelvetri I., Ph D., Zheng K., Katie E., Tan Y. B., Arzberger T., et al. (2013) Somatic mitochondrial DNA mutations in early Parkinson's and incidental Lewy body disease. Ann. Neurol. 71, 850-854.

Lin M. T., Cantuti-Castelvetri I., Zheng K., Jackson K. E., Tan Y. B., Arzberger T., Lees A. J., Betensky R. A., Beal M. F., Simon D. K. (2012) Somatic mitochondrial DNA mutations in early Parkinson and incidental Lewy body disease. Ann. Neurol. 71, 850-4.

Lloyd K. G., Shemen L., Hornykiewicz O. (1977) Distribution of high affinity sodium-independent [3H]gamma-aminobutyric acid binding in the human brain: alterations in Parkinson's disease. Brain Res. 127, 269-278.

Loeffler D. a, Camp D. M., Conant S. B. (2006) Complement activation in the Parkinson's disease substantia nigra: an immunocytochemical study. J. Neuroinflammation 3, 29.

Lonskaya I., Hebron M. L., Algarzae N. K., Desforges N., Moussa C. E.-H. (2013) Decreased parkin solubility is associated with impairment of autophagy in the nigrostriatum of sporadic Parkinson's disease. Neuroscience 232, 90-105.

Lorenzl S., Albers D. S., Narr S., Chirichigno J., Beal M. F. (2002) Expression of MMP-2, MMP-9, and MMP-1 and their endogenous counterregulators TIMP-1 and TIMP-2 in postmortem brain tissue of Parkinson's disease. Exp. Neurol. 178, 13-20.

Maetzler W., Berg D., Schalamberidze N., Melms A., Schott K., Mueller J. C., Liaw L., Gasser T., Nitsch C. (2007) Osteopontin is elevated in Parkinson's disease and its absence leads to reduced neurodegeneration in the MPTP model. Neurobiol. Dis. 25, 473-82.

Mahul-Mellier a.-L., Fauvet B., Gysbers A., Dikiy I., Oueslati A., Georgeon S., Lamontanara a. J., et al. (2014) c-Abl phosphorylates alpha-synuclein and regulates its degradation: implication for alpha-synuclein clearance and contribution to the pathogenesis of Parkinson's disease. Hum. Mol. Genet. 23, 2858-2879.

Malagelada C., Jin Z. H., Greene L. (2008) RTP801 is induced in Parkinson's disease and mediates neuron death by inhibiting Akt phosphorylation/activation. J. Neurosci. 28, 14363-71.

Malagelada C., Ryu E. J., Biswas S. C., Jackson-Lewis V., Greene L. a (2006) RTP801 is elevated in Parkinson brain substantia nigral neurons and mediates death in cellular models of Parkinson's disease by a mechanism involving mammalian target of rapamycin inactivation. J. Neurosci. 26, 9996-10005.

Mandel S. A., Fishman T., Youdim M. B. H. (2007) Gene and protein signatures in sporadic Parkinson's disease and a novel genetic model of PD. Parkinsonism Relat. Disord. 13, S242- 
S247.

Mandel S. a., Fishman-Jacob T., Youdim M. B. H. (2009) Modeling sporadic Parkinson's disease by silencing the ubiquitin E3 ligase component, SKP1A. Park. Relat. Disord. 15, S148-S151.

Mann V. M., Cooper J. M., Daniel S. E., Srai K., Jenner P., Marsden C. D., Schapira A. H. (1994) Complex I, iron, and ferritin in Parkinson's disease substantia nigra. Ann. Neurol. 36, 876-81.

Mantle D., Falkous G., Ishiura S., Blanchard P. J., Perry E. K. (1996) Comparison of proline endopeptidase activity in brain tissue from normal cases and cases with Alzheimer's disease, Lewy body dementia, Parkinson's disease and Huntington's disease. Clin. Chim. Acta 249, 129139.

Mantle D., Falkous G., Ishiura S., Perry R. H., Perry E. K. (1995) Comparison of cathepsin protease activities in brain tissue from normal cases and cases with Alzheimer's disease, Lewy body dementia, Parkinson's disease and Huntington's disease. J. Neurol. Sci. 131, 65-70.

Marshall K. A., Daniel S. E., Cairns N., Jenner P., Halliwell B. (1997) Upregulation of the antiapoptotic protein Bcl-2 may be an early event in neurodegeneration: studies on Parkinson's and incidental Lewy body disease. Biochem. Biophys. Res. Commun. 240, 84-87.

Martinez-Mir M. I., Pollard H., Moreau J., Traiffort E., Ruat M., Schwartz J. C., Palacios J. M. (1993) Loss of striatal histamine $\mathrm{H} 2$ receptors in Huntington's chorea but not in Parkinson's disease: Comparison with animal models. Synapse 15, 209-220.

Marttila R. J., Lorentz H., Rinne U. K. (1988) Oxygen toxicity protecting enzymes in Parkinson's disease. Increase of superoxide dismutase-like activity in the substantia nigra and basal nucleus. J. Neurol. Sci. 86, 321-331.

Mash D. C., Pablo J., Buck B. E., Sanchez-Ramos J., Weiner W. J. (1991) Distribution and number of transferrin receptors in Parkinson's disease and in MPTP-treated mice. Exp. Neurol. 114, 73-81.

Mastroberardino P. G., Hoffman E. K., Horowitz M. P., Betarbet R., Taylor G., Cheng D., Na H. M., et al. (2009) A novel transferrin/TfR2-mediated mitochondrial iron transport system is disrupted in Parkinson's disease. Neurobiol. Dis. 34, 417-31.

Mattila P., Röyttä M., Lönnberg P., Marjamäki P., Helenius H., Rinne J. O. (2001) Choline acetyltransferase activity and striatal dopamine receptors in Parkinson's disease in relation to cognitive impairment. Acta Neuropathol 102, 160-166.

McNaught K., Belizaire R., Isacson O., Jenner P., Olanow C. W. (2003) Altered Proteasomal Function in Sporadic Parkinson's Disease. Exp. Neurol. 179, 38-46.

McNaught K. S. P., Jenner P. (2001) Proteasomal function is impaired in substantia nigra in Parkinson's disease. Neurosci. Lett. 297, 191-194.

Michael G. J., Esmailzadeh S., Moran L. B., Christian L., Pearce R. K. B., Graeber M. B. (2011) Upregulation of metallothionein gene expression in parkinsonian astrocytes. Neurogenetics 12, 295305.

Miki Y., Tanji K., Mori F., Utsumi J., Sasaki H., Kakita A., Takahashi H., Wakabayashi K. (2015) Alteration of upstream autophagy-related proteins (ULK1, ULK2, Beclin1, VPS34, and AMBRA1) in Lewy body disease. Brain Pathol.

Miklossy J., Doudet D. D., Schwab C., Yu S., McGeer E. G., McGeer P. L. (2006) Role of ICAM-1 in persisting inflammation in Parkinson disease and MPTP monkeys. Exp. Neurol. 197, 275-83.

Miller G. W., Erickson J. D., Perez J. T., Penland S. N., Mash D. C., Rye D. B., Levey A. I. (1999) Immunochemical analysis of vesicular monoamine transporter (VMAT2) protein in Parkinson's disease. Exp. Neurol. 156, 138-148. 
Mirza B., Hadberg H., Thomsen P., Moos T. (1999) The absence of reactive astrocytosis is indicative of a unique inflammatory process in Parkinson's disease. Neuroscience 95, 425-432.

Mizuno Y., Matuda S., Yoshino H., Mori H., Hattori N., Ikebe S. (1994) An immunohistochemical study on alpha-ketoglutarate dehydrogenase complex in Parkinson's disease. Ann. Neurol. 35, 204-10.

Mochizuki H., Goto K., Mori H., Mizuno Y. (1996) Histochemical detection of apoptosis in Parkinson's disease. J. Neurol. Sci. 137, 120-123.

Mogi M., Harada M., Kondo T., Mizuno Y., Narabayashi H., Riederer P., Nagatsu T. (1996a) The soluble form of Fas molecule is elevated in parkinsonian brain tissues. Neurosci. Lett. 220, 195 198.

Mogi M., Harada M., Kondo T., Narabayashi H., Riederer P., Nagatsu T. (1995) Transforming growth factor-beta 1 levels are elevated in the striatum and in ventricular cerebrospinal fluid in Parkinson's disease. Neurosci. Lett. 193, 129-132.

Mogi M., Harada M., Kondo T., Riederer P., Inagaki H., Minami M., Nagatsu T. (1994a) Interleukin-1 beta, interleukin-6, epidermal growth factor and transforming growth factor-alpha are elevated in the brain from parkinsonian patients. Neurosci. Lett. 180, 147-50.

Mogi M., Harada M., Kondo T., Riederer P., Nagatsu T. (1996b) Interleukin-2 but not basic fibroblast growth factor is elevated in parkinsonian brain. J. Neural Transm. 103, 1077-81.

Mogi M., Harada M., Riederer P., Narabayashi H., Fujita K., Nagatsu T. (1994b) Tumor necrosis factor-alpha (TNF-alpha) increases both in the brain and in the cerebrospinal fluid from parkinsonian patients. Neurosci. Lett. 165, 208-10.

Mogi M., Kondo T., Mizuno Y., Nagatsu T. (2007) p53 protein, interferon-gamma, and NF-kappaB levels are elevated in the parkinsonian brain. Neurosci. Lett. 414, 94-7.

Mogi M., Togari A., Kondo T., Mizuno Y., Kogure O., Kuno S., Ichinose H., Nagatsu T. (2001) Glial cell line-derived neurotrophic factor in the substantia nigra from control and parkinsonian brains. Neurosci. Lett. 300, 179-181.

Mogi M., Togari A., Kondo T., Mizuno Y., Komure O., Kuno S., Ichinose H., Nagatsu T. (1999) Brain-derived growth factor and nerve growth factor concentrations are decreased in the substantia nigra in Parkinson's disease. Neurosci. Lett. 270, 45-48.

Mogi M., Togari A., Kondo T., Mizuno Y., Komure O., Kuno S., Ichinose H., Nagatsu T. (2000) Caspase activities and tumor necrosis factor receptor R1 (p55) level are elevated in the substantia nigra from parkinsonian brain. J. Neural Transm. 107, 335-41.

Moisoi N., Klupsch K., Fedele V., East P., Sharma S., Renton a, Plun-Favreau H., et al. (2009) Mitochondrial dysfunction triggered by loss of HtrA2 results in the activation of a brain-specific transcriptional stress response. Cell Death Differ. 16, 449-64.

Montis G. de, Beaumont K., Javoy-Agid F., Agid Y., Constandinidis J., Lowenthal A., Lloyd K. G. (1982) Glycine receptors in the human substantia nigra as defined by $[3 \mathrm{H}]$ strychnine binding. $J$ Neurochem 38, 718-724.

Moos T., Jensen P. H. (2004) Absence of prostate apoptosis response-4 protein in substantia nigra of Parkinson's disease autopsies. Acta Neuropathol. 107, 23-6.

Morais V. A., Haddad D., Craessaerts K., Bock P.-J. De, Swerts J., Vilain S., Aerts L., et al. (2014) PINK1 loss-of-function mutations affect mitochondrial complex I activity via NdufA10 ubiquinone uncoupling. Science 344, 203-7.

Morgan M. J., Liu Z. (2011) Crosstalk of reactive oxygen species and NF-kB signaling. Cell Res. 21, 
103-115.

Moroo I., Yamada T., Makino H., Tooyama I., McGreer P. L., McGeer E. G., Hirayama K. (1994) Loss of insulin receptor immunoreactivity from the substantia nigra pars compacta neurons in Parkinson's disease.

Mouatt-Prigent A., Karlsson J. O., Agid Y., Hirsch E. C. (1996) Increased M-calpain expression in the mesencephalon of patients with Parkinson's disease but not in other neurodegenerative disorders involving the mesencephalon: a role in nerve cell death? Neuroscience.

Mouatt-Prigent A., Karlsson J. O., Yelnik J., Agid Y., Hirsch E. C. (2000) Calpastatin immunoreactivity in the monkey and human brain of control subjects and patients with Parkinson's disease. J. Comp. Neurol. 419, 175-92.

Muiswinkel F. L. van, Vos R. a I. de, Bol J. G. J. M., Andringa G., Jansen Steur E. N. H., Ross D., Siegel D., Drukarch B. (2004) Expression of NAD(P)H quinone oxidoreductase in the normal and Parkinsonian substantia nigra. Neurobiol. Aging 25, 1253-62.

Muqit M. M. K., Abou-Sleiman P. M., Saurin A. T., Harvey K., Gandhi S., Deas E., Eaton S., et al. (2006) Altered cleavage and localization of PINK1 to aggresomes in the presence of proteasomal stress. J. Neurochem. 98, 156-69.

Murphy K. E., Gysbers A. M., Abbott S. K., Tayebi N., Kim W. S., Sidransky E., Cooper A., Garner B., Halliday G. M. (2014) Reduced glucocerebrosidase is associated with increased $\alpha$-synuclein in sporadic Parkinson's disease. Brain 137, 834-48.

Mythri R. B., Venkateshappa C., Harish G., Mahadevan A., Muthane U. B., Yasha T. C., Srinivas Bharath M. M., Shankar S. K. (2011) Evaluation of markers of oxidative stress, antioxidant function and astrocytic proliferation in the striatum and frontal cortex of Parkinson's disease brains. Neurochem. Res. 36, 1452-63.

Nakabeppu Y., Tsuchimoto D., Yamaguchi H., Sakumi K. (2007) Oxidative Damage in Nucleic Acids and Parkinson's Disease. J. Neurosci. Res. 934, 919-934.

Nakamura A., Kitami T., Mori H., Mizuno Y., Hattori N. (2006) Nuclear localization of the $20 \mathrm{~S}$ proteasome subunit in Parkinson's disease. Neurosci. Lett. 406, 43-8.

Navarro A., Boveris A., Bández M. J., Sánchez-Pino M. J., Gómez C., Muntané G., Ferrer I. (2009) Human brain cortex: mitochondrial oxidative damage and adaptive response in Parkinson disease and in dementia with Lewy bodies. Free Radic. Biol. Med. 46, 1574-80.

Oakley A. E., Collingwood J. F., Dobson J., Love G., Perrott H. R., Edwardson J. A., Elstner M., Morris C. M. (2007) Individual dopaminergic neurons show raised iron levels in Parkinson disease. Neurology 68, 1820-5.

Ordoñez C., Navarro A., Perez C., Astudillo A., Martínez E., Tolivia J. (2006) Apolipoprotein D expression in substantia nigra of Parkinson disease. Histol. Histopathol. 21, 361-366.

Orr C. F., Rowe D. B., Mizuno Y., Mori H., Halliday G. M. (2005) A possible role for humoral immunity in the pathogenesis of Parkinson's disease. Brain 128, 2665-74.

Orsucci D., Caldarazzo Ienco E., Mancuso M., Siciliano G. (2011) POLG1-related and other "mitochondrial Parkinsonisms": an overview. J. Mol. Neurosci. 44, 17-24.

Ozawa T., Hayakawa M., Katsumata K., Yoneda M., Ikebe S., Mizuno Y. (1997) Fragile mitochondrial DNA: the missing link in the apoptotic neuronal cell death in Parkinson's disease. Biochem. Biophys. Res. Commun. 235, 158-161.

Parain K., Murer M. G., Yan Q., Faucheux B., Agid Y., Hirsch E., Raisman-Vozari R. (1999) Reduced expression of brain-derived neurotrophic factor protein in Parkinson's disease substantia nigra. 
Neuroreport 10, 557-561.

Parker W. D., Parks J. K., Swerdlow R. H. (2008) Complex I deficiency in Parkinson's disease frontal cortex. Brain Res. 1189, 215-218.

Parsons R. B., Smith S. W., Waring R. H., Williams A. C., Ramsden D. B. (2003) High expression of nicotinamide N-methyltransferase in patients with idiopathic Parkinson's disease. Neurosci. Lett. 342, 13-16

Pearce R. K. B., Owen A., Daniel S., Jenner P., Marsden C. D. (1997) Alterations in the distribution of glutathione in the substantia nigra in Parkinson's disease. J. Neural Transm. 104, 661-677.

Pey P., Pearce R. K. B., Kalaitzakis M. E., Griffin W. S. T., Gentleman S. M. (2014) Phenotypic profile of alternative activation marker CD163 is different in Alzheimer's and Parkinson's disease. Acta Neuropathol. Commun. 2, 21.

Pickrell A. M., Youle R. J. (2015) The Roles of PINK1, Parkin, and Mitochondrial Fidelity in Parkinson's Disease. Neuron 85, 257-273.

Piggott M. A., Ballard C. G., Dickinson H. O., McKeith I. G., Perry R. H., Perry E. K. (2007) Thalamic D2 receptors in dementia with Lewy bodies, Parkinson's disease, and Parkinson's disease dementia. Int. J. Neuropsychopharmacol. 10, 231-44.

Piggott M. A., Marshall E. F., Thomas N., Lloyd S., Court J. A., Jaros E., Burn D., et al. (1999) Striatal dopaminergic markers in dementia with Lewy bodies, Alzheimer's and Parkinson's diseases : rostrocaudal distribution. Brain 122, 1449-1468.

Plun-Favreau H., Klupsch K., Moisoi N., Gandhi S., Kjaer S., Frith D., Harvey K., et al. (2007) The mitochondrial protease HtrA2 is regulated by Parkinson's disease-associated kinase PINK1. Nat. Cell Biol. 9, 1243-52.

Polymeropoulos M. H., Lavedan C., Leroy E., Ide S. E., Dehejia A., Dutra A., Pike B., et al. (1997) Mutation in the $\alpha$-Synuclein Gene Identified in Families with Parkinson's Disease. Science 276, 2045-2047.

Power J. H. T., Shannon J. M., Blumbergs P. C., Gai W. (2002) Nonselenium glutathione peroxidase in human brain. Am. J. Pathol. 161, 885-894.

Pranski E. L., Dalal N. V., Sanford C. Van, Herskowitz J. H., Gearing M., Lazo C., Miller G. W., Lah J. J., Levey A. I., Betarbet R. S. (2013) RING finger protein 11 (RNF11) modulates susceptibility to 6-OHDA-induced nigral degeneration and behavioral deficits through NF-KB signaling in dopaminergic cells. Neurobiol. Dis. 54, 264-279.

Press P., Waeber C. (1989) Serotonin-1 receptor binding sites in the human basal ganglia are decreased in Huntington's chorea but not in Parkinson's disease: a quantitative in vitro autoradiography study. Neuroscience 32, 337-347.

Price D. L., Rockenstein E., Ubhi K., Phung V., MacLean-Lewis N., Askay D., Cartier A., et al. (2010) Alterations in mGluR5 expression and signaling in Lewy body disease and in transgenic models of alpha-synucleinopathy--implications for excitotoxicity. PLoS One 5, e14020.

Qu D., Rashidian J., Mount M. P., Aleyasin H., Parsanejad M., Lira A., Haque E., et al. (2007) Role of Cdk5-mediated phosphorylation of Prx2 in MPTP toxicity and Parkinson's disease. Neuron 55, $37-52$.

Radunović A., Porto W. G., Zeman S., Leigh P. N. (1997) Increased mitochondrial superoxide dismutase activity in Parkinson's disease but not amyotrophic lateral sclerosis motor cortex. Neurosci. Lett. 239, 105-8.

Ramonet D., Podhajska A., Stafa K., Sonnay S., Trancikova A., Tsika E., Pletnikova O., Troncoso J. 
C., Glauser L., Moore D. J. (2012) PARK9-associated ATP13A2 localizes to intracellular acidic vesicles and regulates cation homeostasis and neuronal integrity. Hum. Mol. Genet. 21, 1725-43.

Ramsey C. P., Glass C. A., Montgomery M. B., Lindl K. A., Ritson G. P., Chia L. A., Hamilton R. L., Chu C. T., Jordan-Sciutto K. L. (2007) Expression of Nrf2 in neurodegenerative diseases. $J$. Neuropathol. Exp. Neurol. 66, 75-85.

Reynolds A. D., Glanzer J. G., Kadiu I., Ricardo-Dukelow M., Chaudhuri A., Ciborowski P., Cerny R., et al. (2008) Nitrated alpha-synuclein-activated microglial profiling for Parkinson's disease. J. Neurochem. 104, 1504-25.

Riederer P., Sofic E., Rausch W. D., Schmidt B., Reynolds G. P., Jellinger K., Youdim M. B. (1989) Transition metals, ferritin, glutathione, and ascorbic acid in parkinsonian brains. J. Neurochem. 52, 515-20.

Rieker C., Engblom D., Kreiner G., Domanskyi A., Schober A., Stotz S., Neumann M., et al. (2011) Nucleolar disruption in dopaminergic neurons leads to oxidative damage and parkinsonism through repression of mammalian target of rapamycin signaling. J. Neurosci. 31, 453-60.

Rijk M. C. de, Launer L. J., Berger K., Breteler M. M., Dartigues J. F., Baldereschi M., Fratiglioni L., et al. (2000) Prevalence of Parkinson's disease in Europe: A collaborative study of populationbased cohorts. Neurologic Diseases in the Elderly Research Group. Neurology 54, S21-S23.

Rinne J. O., Lnnberg P., Marjam P., Rinne U. K. (1989) Brain muscarinic receptor subtypes are differently affected in Alzheimer's disease and Parkinson's disease. Brain Res. 483, 402-406.

Rohn T. T., Catlin L. W. (2011) Immunolocalization of influenza A virus and markers of inflammation in the human Parkinson's disease brain. PLoS One 6, e20495.

Ros-Bernal F., Hunot S., Herrero M. T., Parnadeau S., Corvol J.-C., Lu L., Alvarez-Fischer D., et al. (2011) Microglial glucocorticoid receptors play a pivotal role in regulating dopaminergic neurodegeneration in parkinsonism. Proc. Natl. Acad. Sci. U. S. A. 108, 6632-7.

Ross B. M., Mamalias N., Moszczynska A., Rajput A. H., Kish S. J. (2001) Elevated activity of phospholipid biosynthetic enzymes in substantia nigra of patients with Parkinson's disease. Neuroscience 102, 7-12.

Rothaug M., Zunke F., Mazzulli J. R., Schweizer M., Altmeppen H., Lüllmann-Rauch R., Kallemeijn W. W., et al. (2014) LIMP-2 expression is critical for $\beta$-glucocerebrosidase activity and $\alpha$ synuclein clearance. Proc. Natl. Acad. Sci. U. S. A. 111, 15573-8.

Rott R., Szargel R., Haskin J., Bandopadhyay R., Lees A., Shani V., Engelender S. (2011) $\alpha$-Synuclein fate is determined by USP9X-regulated monoubiquitination. Proc. Natl. Acad. Sci. 108, 1866671.

Rousseau E., Michel P. P., Hirsch E. C. (2013) The iron-binding protein lactoferrin protects vulnerable dopamine neurons from degeneration by preserving mitochondrial calcium homeostasis. Mol. Pharmacol. 84, 888-98.

Rubio de la Torre E., Luzón-Toro B., Forte-Lago I., Minguez-Castellanos A., Ferrer I., Hilfiker S. (2009) Combined kinase inhibition modulates parkin inactivation. Hum. Mol. Genet. 18, 809-23.

Ryoo H. L., Dylan B. S., Bs P., Joyce J. N. (1998) Dopamine D3 Receptor is Decreased and D2 Receptor is Elevated in the Striatum of Parkinson's Disease. Isis 13, 788-797.

Saito Y., Miyasaka T., Hatsuta H., Takahashi-Niki K., Hayashi K., Mita Y., Kusano-Arai O., et al. (2014) Immunostaining of oxidized DJ-1 in human and mouse brains. J. Neuropathol. Exp. Neurol. 73, 714-28.

Salazar J., Mena N., Hunot S., Prigent A., Alvarez-Fischer D., Arredondo M., Duyckaerts C., et al. 
(2008) Divalent metal transporter 1 (DMT1) contributes to neurodegeneration in animal models of Parkinson's disease. Proc. Natl. Acad. Sci. U. S. A. 105, 18578-18583.

Sanders L. H., McCoy J., Hu X., Mastroberardino P. G., Dickinson B. C., Chang C. J., Chu C. T., Houten B. Van, Greenamyre J. T. (2014) Mitochondrial DNA damage: Molecular marker of vulnerable nigral neurons in Parkinson's disease. Neurobiol. Dis. 70, 214-223.

Sathe K., Maetzler W., Lang J. D., Mounsey R. B., Fleckenstein C., Martin H. L., Schulte C., et al. (2012) S100B is increased in Parkinson's disease and ablation protects against MPTP-induced toxicity through the RAGE and TNF- $\alpha$ pathway. Brain 135, 3336-47.

Schapira A. H., Cooper J. M., Dexter D., Jenner P., Clark J. B., Marsden C. D. (1989) Mitochondrial complex I deficiency in Parkinson's disease. Lancet 1, 1269.

Schapira A. H., Mann V. M., Cooper J. M., Dexter D., Daniel S. E., Jenner P., Clark J. B., Marsden C. D. (1990) Anatomic and disease specificity of NADH CoQ1 reductase (complex I) deficiency in Parkinson's disease. J. Neurochem. 55, 2142-2145.

Schipper H. M. (2004) Heme oxygenase expression in human central nervous system disorders. Free Radic. Biol. Med. 37, 1995-2011.

Schipper H. M., Song W., Zukor H., Hascalovici J. R., Zeligman D. (2009) Heme oxygenase-1 and neurodegeneration: expanding frontiers of engagement. J. Neurochem. 110, 469-485.

Schlossmacher M. G., Frosch M. P., Gai W. P., Medina M., Sharma N., Forno L., Ochiishi T., et al. (2002) Parkin localizes to the Lewy bodies of Parkinson disease and dementia with Lewy bodies. Am. J. Pathol. 160, 1655-1667.

Schwab B. C., Heida T., Zhao Y., Gils S. a van, Wezel R. J. a van (2014) Pallidal gap junctionstriggers of synchrony in Parkinson's disease? Mov. Disord. 29, 1486-94.

Seirafi M., Kozlov G., Gehring K. (2015) Parkin structure and function. FEBS J. 282, 2076-88.

Shamoto-Nagai M., Maruyama W., Hashizume Y., Yoshida M., Osawa T., Riederer P., Naoi M. (2007) In parkinsonian substantia nigra, alpha-synuclein is modified by acrolein, a lipidperoxidation product, and accumulates in the dopamine neurons with inhibition of proteasome activity. J. Neural Transm. 114, 1559-67.

Sharma M., Burre J., Sudhof T. C. (2012) Proteasome inhibition alleviates SNARE-dependent neurodegeneration. Sci. Transl. Med. 4, 147 ra113.

Sharon R., Bar-joseph I., Frosch M. P., Walsh D. M., Hamilton J. A., Selkoe D. J. (2003) The Formation of Highly Soluble Oligomers of alpha -Synuclein Is Regulated by Fatty Acids and Enhanced in Parkinson's Disease. Neuron 37, 583-595.

She H., Yang Q., Shepherd K., Smith Y., Miller G., Testa C., Mao Z. (2011) Direct regulation of complex I by mitochondrial MEF2D is disrupted in a mouse model of Parkinson disease and in human patients. J. Clin. Invest. 121, 930-940.

Shehadeh L., Mitsi G., Adi N., Bishopric N., Papapetropoulos S. (2009) Expression of Lewy body protein septin 4 in postmortem brain of Parkinson's disease and control subjects. Mov. Disord. 24, 204-10.

Shephard F., Greville-Heygate O., Marsh O., Anderson S., Chakrabarti L. (2014) A mitochondrial location for haemoglobins-Dynamic distribution in ageing and Parkinson's disease.

Mitochondrion 14, 64-72.

Shimoda-Matsubayashi S., Hattori T., Matsumine H., Shinohara A., Yoritaka A., Mori H., Kondo T., Chiba M., Mizuno Y. (1997) Mn SOD activity and protein in a patient with chromosome 6linked autosomal recessive parkinsonism in comparison with Parkinson's disease and control. 
Neurology 49, 1257-62.

Shimoji M., Pagan F., Healton E. B., Mocchetti I. (2009) CXCR4 and CXCL12 expression is increased in the nigro-striatal system of Parkinson's disease. Neurotox. Res. 16, 318-28.

Shimura-Miura H., Hattori N., Kang D., Miyako K., Nakabeppu Y., Mizuno Y. (1999) Increased 8oxo-dGTPase in the mitochondria of substantia nigral neurons in Parkinson's disease. Ann. Neurol. 46, 920-4.

Shin J.-H., Ko H. S., Kang H., Lee Y., Lee Y.-I., Pletinkova O., Troconso J. C., Dawson V. L., Dawson T. M. (2011) PARIS (ZNF746) repression of PGC-1 $\alpha$ contributes to neurodegeneration in Parkinson's disease. Cell 144, 689-702.

Sian J., Dexter D. T., Lees a J., Daniel S., Agid Y., Javoy-Agid F., Jenner P., Marsden C. D. (1994) Alterations in glutathione levels in Parkinson's disease and other neurodegenerative disorders affecting basal ganglia. Ann. Neurol. 36, 348-355.

Slodzinski H., Moran L. B., Michael G. J., Wang B., Novoselov S., Cheetham M. E., Graeber M. B. (2009) Homocysteine-induced endoplasmic reticulum protein (Herp) is up-regulated in parkinsonian substantia nigra and present in the core of Lewy bodies. Clin. Neuropathol. 28, 333-343.

Slone S. R., Lavalley N., McFerrin M., Wang B., Yacoubian T. A. (2015) Increased 14-3-3 phosphorylation observed in Parkinson's disease reduces neuroprotective potential of 14-3-3 proteins. Neurobiol. Dis. 79, 1-13.

Sofic E., Lange K. W., Jellinger K., Riederer P. (1992) Reduced and oxidized glutathione in the substantia nigra of patients with Parkinson's disease. Neurosci. Lett. 142, 128-130.

Soós J., Engelhardt J. I., Siklós L., Havas L., Majtényi K. (2004) The expression of PARP, NF-kappa $\mathrm{B}$ and parvalbumin is increased in Parkinson disease. Neuroreport 15, 1715-8.

Spencer J. P., Jenner P., Daniel S. E., Lees A. J., Marsden D. C., Halliwell B. (1998) Conjugates of catecholamines with cysteine and GSH in Parkinson's disease: possible mechanisms of formation involving reactive oxygen species. J. Neurochem. 71, 2112-22.

Stanzione P., Tropepi D. (2011) Drugs and clinical trials in neurodegenerative diseases. Ann. Ist. Super. Sanita 47, 49-54.

Steiner J. A., Angot E., Brundin P. (2011) A deadly spread: cellular mechanisms of $\alpha$-synuclein transfer. Cell Death Differ. 18, 1425-1433.

Sunico C. R., Nakamura T., Rockenstein E., Mante M., Adame A., Chan S. F., Newmeyer T. F., Masliah E., Nakanishi N., Lipton S. a (2013) S-Nitrosylation of parkin as a novel regulator of p53-mediated neuronal cell death in sporadic Parkinson's disease. Mol. Neurodegener. 8, 29.

Szegezdi E., Logue S. E., Gorman A. M., Samali A. (2006) Mediators of endoplasmic reticulum stress-induced apoptosis. EMBO Rep. 7, 880-885.

Tanaka C., Nishino N., Hashimoto T., Kitamura N., Yoshihara C., Saito N. (1993) Second messenger systems in brains of patients with Parkinson's or Huntington's disease. Adv. Neurol. 60, 175-80.

Tanji K., Kamitani T., Mori F., Kakita A., Takahashi H., Wakabayashi K. (2010) TRIM9, a novel brain-specific E3 ubiquitin ligase, is repressed in the brain of Parkinson's disease and dementia with Lewy bodies. Neurobiol. Dis. 38, 210-218.

Tatton N. (2000) Increased caspase-3 and Bax immunoreactivity accompany nuclear GAPDH translocation and neuronal apoptosis in Parkinson's disease. Exp. Neurol. 166, 29-43.

Teismann P., Tieu K., Choi D., Wu D., Naini A., Hunot S., Vila M., Jackson-Lewis V., Przedborski S. (2003) Cyclooxygenase-2 is instrumental in Parkinson's disease neurodegeneration. Proc. Natl. 
Acad. Sci. U. S. A. 100, 5473-5478.

Thibaut F., Faucheux B. A., Marquez J., Villares J., Menard J. F., Agid Y., Hirsch E. C. (1995) Regional distribution of monoamine vesicular uptake sites in the mesencephalon of control subjects and patients with Parkinson's disease: a postmortem study using tritiated tetrabenazine. Brain Res. 692, 233-243.

Timmons S., Coakley M. F., Moloney A. M., O’ Neill C. (2009) Akt signal transduction dysfunction in Parkinson's disease. Neurosci. Lett. 467, 30-5.

Tofaris G. K., Kim H. T., Hourez R., Jung J.-W., Kim K. P., Goldberg A. L. (2011) Ubiquitin ligase Nedd4 promotes a-synuclein degradation by the endosomal-lysosomal pathway. Proc. Natl. Acad. Sci. 108, 17004-9.

Tompkins M. M., Basgall E. J., Zamrini E., Hill W. D. (1997) Apoptotic-like changes in Lewy-bodyassociated disorders and normal aging in substantia nigral neurons. Am. J. Pathol. 150, 119-131.

Tong J., Ang L.-C., Williams B., Furukawa Y., Fitzmaurice P., Guttman M., Boileau I., Hornykiewicz O., Kish S. J. (2015) Low levels of astroglial markers in Parkinson's disease: relationship to $\alpha$ synuclein accumulation. Neurobiol. Dis. 82, 243-253.

Tooyama I., McGeer E. G., Kawamata T., Kimura H., McGeer P. L. (1994) Retention of basic fibroblast growth factor immunoreactivity in dopaminergic neurons of the substantia nigra during normal aging in humans contrasts with loss in Parkinson's disease. Brain Res. 656, 165-168.

Tsika E., Glauser L., Moser R., Fiser A., Daniel G., Sheerin U. M., Lees A., et al. (2014) Parkinson's disease-linked mutations in VPS35 induce dopaminergic neurodegeneration. Hum. Mol. Genet. 23, 4621-4638.

Uhl G. R., Hackney G. O., Torchia M., Stranov V., Tourtellotte W. W., Whitehouse P. J., Tran V., Strittmatter S. (1986) Parkinson's disease: nigral receptor changes support peptidergic role in nigrostriatal modulation. Ann. Neurol. 20, 194-203.

Varani K., Vincenzi F., Tosi A., Gessi S., Casetta I., Granieri G., Fazio P., et al. (2010) A2A adenosine receptor overexpression and functionality, as well as TNF-alpha levels, correlate with motor symptoms in Parkinson's disease. FASEB J. 24, 587-98.

Villar-Menéndez I., Porta S., Buira S. P., Pereira-Veiga T., Díaz-Sánchez S., Albasanz J. L., Ferrer I., Martín M., Barrachina M. (2014) Increased striatal adenosine A2A receptor levels is an early event in Parkinson's disease-related pathology and it is potentially regulated by miR-34b. Neurobiol. Dis. 69, 206-14.

Vilotti S., Codrich M., Dal Ferro M., Pinto M., Ferrer I., Collavin L., Gustincich S., Zucchelli S. (2012) Parkinson's disease DJ-1 L166P alters rRNA biogenesis by exclusion of TTRAP from the nucleolus and sequestration into cytoplasmic aggregates via TRAF6. PLoS One 7, e35051.

Visanji N. P., Collingwood J. F., Finnegan M. E., Tandon A., House E., Hazrati L.-N. (2013) Iron deficiency in parkinsonism: region-specific iron dysregulation in Parkinson's disease and multiple system atrophy. J. Parkinsons. Dis. 3, 523-37.

Viswanath V., Wu Y., Boonplueang R., Chen S., Stevenson F. F., Yantiri F., Yang L., Beal M. F., Andersen J. K. (2001) Caspase-9 activation results in downstream caspase-8 activation and Bid cleavage in MPTP-induced Parkinson's disease. J. Neurosci. 21, 9519-9528.

Vroon A., Drukarch B., Bol J. G. J. M., Cras P., Brevé J. J. P., Allan S. M., Relton J. K., Hoogland P. V. J. M., Dam A.-M. Van (2007) Neuroinflammation in Parkinson's patients and MPTP-treated mice is not restricted to the nigrostriatal system: microgliosis and differential expression of interleukin-1 receptors in the olfactory bulb. Exp. Gerontol. 42, 762-71.

Wakabayashi K., Tanji K., Odagiri S., Miki Y., Mori F., Takahashi H. (2013) The Lewy body in 
Parkinson's disease and related neurodegenerative disorders. Mol. Neurobiol. 47, 495-508.

Walker D. G., Beach T. G., Xu R., Lile J., Beck K. D., McGeer E. G., L. McGeer P. (1998a) Expression of the proto-oncogene Ret, a component of the GDNF receptor complex, persists in human substantia nigra neurons in Parkinson's disease. Brain Res. 792, 207-17.

Walker D. G., Terai K., Matsuo A., Beach T. G., McGeer E. G., McGeer P. L. (1998b) Immunohistochemical analyses of fibroblast growth factor receptor-1 in the human substantia nigra. Comparison between normal and Parkinson's disease cases. Brain Res. 794, 181-7.

Watson D. L., Carpenter C. L., Marks S. S., Greenberg D. A. (1988) Striatal calcium channel antagonist receptors in Huntington's disease and Parkinson's disease. Ann. Neurol. 23, 303-305.

Westerlund M., Belin A. C., Anvret A., Håkansson A., Nissbrandt H., Lind C., Sydow O., Olson L., Galter D. (2008) Cerebellar alpha-synuclein levels are decreased in Parkinson's disease and do not correlate with SNCA polymorphisms associated with disease in a Swedish material. FASEB J. 22, 3509-14.

Wilhelmus M. M. M., Bol J. G. J. M., Haastert E. S. Van, Rozemuller A. J. M., Bu G., Drukarch B., Hoozemans J. J. M. (2011a) Apolipoprotein E and LRP1 increase early in Parkinson's disease pathogenesis. Am J Pathol 179, 2152-2156.

Wilhelmus M. M. M., Verhaar R., Andringa G., Bol J. G. J. M., Cras P., Shan L., Hoozemans J. J. M., Drukarch B. (2011b) Presence of tissue transglutaminase in granular endoplasmic reticulum is characteristic of melanized neurons in Parkinson's disease brain. Brain Pathol. 21, 130-9.

Wills J., Jones J., Haggerty T., Duka V., Joyce J. N., Sidhu A. (2010) Elevated tauopathy and alphasynuclein pathology in postmortem Parkinson's disease brains with and without dementia. Exp. Neurol. 225, 210-8.

Wu H., Chen S., Ammar A.-B., Xu J., Wu Q., Pan K., Zhang J., Hong Y. (2014) Crosstalk between macroautophagy and chaperone-mediated autophagy: Implications for the treatment of neurological diseases. Mol. Neurobiol. 52, 1284-96.

Xuereb J. H., Perry E. K., Candy J. M., Bonham J. R., Perry R. H., Marshall E. (1990) Parameters of cholinergic neurotransmission in the thalamus in Parkinson's disease and Alzheimer's disease. $J$. Neurol. Sci. 99, 185-197.

Yamada T., McGeer P. L., Baimbridge K. G., McGeer E. G. (1990) Relative sparing in Parkinson's disease of substantia nigra dopamine neurons containing calbindin-D28K. Brain Res. 526, 303307.

Yoritaka A., Hattori N., Uchida K., Tanaka M., Stadtman E. R., Mizuno Y. (1996) Immunohistochemical detection of 4-hydroxynonenal protein adducts in Parkinson disease. Proc. Natl. Acad. Sci. U. S. A. 93, 2696-2701.

Zarow C., Lyness S. A., Mortimer J. A., Chui H. C. (2015) Neuronal loss is greater in the locus coeruleus than nucleus basalis and substantia nigra in Alzheimer and Parkinson diseases. 60, $337-341$.

Zhang J., Montine T. J., Smith M. A., Siedlak S. L., Gu G., Robertson D., Perry G. (2002) The mitochondrial common deletion in Parkinson's disease and related movement disorders. Park. Relat. Disord. 8, 165-170.

Zhang X., Tang N., Hadden T. J., Rishi A. K. (2011) Akt, FoxO and regulation of apoptosis. Biochim. Biophys. Acta - Mol. Cell Res. 1813, 1978-1986.

Zhou D., Zhan C., Zhong Q., Li S. (2013) Upregulation of sestrin-2 expression via P53 protects against 1-methyl-4-phenylpyridinium (MPP+) neurotoxicity. J. Mol. Neurosci. 51, 967-75. 
Zhou J., Shao Z., Kerkela R., Ichijo H., Muslin A. J., Pombo C., Force T. (2009) Serine 58 of 14-33zeta is a molecular switch regulating ASK1 and oxidant stress-induced cell death. Mol. Cell. Biol. 29, 4167-4176. 
Table 1. Neurotransmitters and neurotrophic factors changes observed in the human parkinsonian brain at the protein level. Legend: Am: Amygdala; $\mathrm{Ca}$ : Caudate nucleus; $\mathrm{Cb}$ : Cerebellum; Cb Cx: Cerebral cortex; Cg Cx: Cingulate cortex; $\mathrm{Cg}$ Gy: Cingulate gyrus; $\mathrm{Fr}$ Cx: Frontal cortex; Fr Gy: Frontal gyrus; GP: Globus pallidus; Hp: Hippocampus; LC: Locus coeruleus; NAcc: Nucleus accumbens; nb: number; NBM: Nucleus basalis of Meynard; Oc Cx: Occipital cortex; PPN: pedunculopontine nucleus; Pu: Putamen; SN: Substantia nigra; STN: Subthalmic nucleus; Str: Striatum; Th: Thalamus; Tp Cx: Temporal cortex.

Table 2. PD-linked genes changes observed in the human parkinsonian brain at the protein level. Legend: see Table 1.

Table 3. Calcium and transition metal-related proteins changes observed in the human parkinsonian brain. Legend: see Table 1.

Table 4. Changes neuroinflammatory-related proteins observed in the human parkinsonian brain. Legend: see Table 1.

Table 5. Changes in mitochondrial and oxidative stress-related proteins observed in the human parkinsonian brain. Legend: see Table 1.

Table 6. Changes in ubiquitin proteasome system, lysosomal and autophagy proteins observed in the human parkinsonian brain. Legend: see Table 1.

Table 7. Changes in apoptosis-related proteins observed in the human parkinsonian brain. Legend: see Table 1. 
Table 8. Changes in transcription factors and transduction pathways observed in the human parkinsonian brain. Legend: see Table 1. 


\section{Table 1. Neurotransmitters and neurotrophic factors observed in the human}

parkinsonian brain at the protein level. Legend: Am: Amygadala; Ca: Caudate nucleus;

Cb: Cerebellum; Cb Cx: Cerebral cortex; $\mathrm{Cg} \mathrm{Cx}$ : Cingulate cortex; $\mathrm{Cg}$ Gy: Cingulate gyrus;

Fr Cx: Frontal cortex; Fr Gy: Frontal gyrus; GP: Globus pallidus; Hp: Hippocampus; LC:

Locus coeruleus; NAcc: Nucleus accumbens; nb: number; NBM: Nucleus basalis of Meynard;

Oc Cx: Occipital cortex; PPN: pedunculopontine nucleus; Pu: Putamen; SN: Substantia nigra;

STN: Subthalmic nucleus; Str: Striatum; Th: Thalamus; Tp Cx: Temporal cortex.

\begin{tabular}{|c|c|c|c|}
\hline Protein & Ref & Structure & Observation in PD \\
\hline \multicolumn{4}{|c|}{ Neurotransmitters, transporters and receptors } \\
\hline 5-S-Cysteinyl-DOPA & (Spencer et al. 1998) & $\mathrm{SN}$ & $\uparrow$ levels \\
\hline 5-S-Cysteinyl-DOPA & (Spencer et al. 1998) & $\mathrm{GP}, \mathrm{Ca}, \mathrm{Pu}$ & $=$ levels \\
\hline $\begin{array}{l}\text { 5-S-Cysteinyl- } \\
\text { DOPAC }\end{array}$ & (Spencer et al. 1998) & $\mathrm{SN}$ & $\uparrow$ levels \\
\hline $\begin{array}{l}\text { 5-S-Cysteinyl- } \\
\text { DOPAC }\end{array}$ & (Spencer et al. 1998) & $\mathrm{GP}, \mathrm{Ca}, \mathrm{Pu}$ & $=$ levels \\
\hline $\begin{array}{l}\text { 5-S-Cysteinyl- } \\
\text { Dopamine }\end{array}$ & (Spencer et al. 1998) & SN & $\uparrow$ levels \\
\hline $\begin{array}{l}\text { 5-S-Cysteinyl- } \\
\text { Dopamine }\end{array}$ & (Spencer et al. 1998) & $\mathrm{GP}, \mathrm{Ca}, \mathrm{Pu}$ & $=$ levels \\
\hline A2A receptor & (Varani et al. 2010) & $\mathrm{Pu}$ & $\uparrow$ level and density \\
\hline A2A receptor & (Villar-Menéndez et al. 2014) & Str & $\begin{array}{l}\uparrow \text { levels in medium } \\
\text { spiny neurons }\end{array}$ \\
\hline AchE & (Xuereb et al. 1990) & Th & $=$ activity \\
\hline AchE & (Xuereb et al. 1990) & STN & $\downarrow$ activity \\
\hline AchR & (Griffiths et al. 1990) & $\mathrm{Ca}, \mathrm{Pu}, \mathrm{Tp} \mathrm{Cx}$ & $=$ density \\
\hline AchR & (Griffiths et al. 1990) & GP & $\uparrow$ density \\
\hline AchR & (Gotti et al. 2006) & Str & $\downarrow$ density \\
\hline AchR (nicotinic) & (Court et al. 2000) & $\mathrm{Ca}, \mathrm{Pu}$ & $\downarrow$ density \\
\hline AchR (nicotinic) & (Xuereb et al. 1990) & STN,Th, Tp Cx & $=$ density \\
\hline $\operatorname{AchR}(\alpha 2$ subunit $)$ & (Gotti et al. 2006) & Str, Tp Cx & $=$ levels \\
\hline AchR ( $\alpha 3$ subunit) & (Gotti et al. 2006) & Str, Tp Cx & $=$ levels \\
\hline AchR ( $\alpha 4$ subunit) & (Gotti et al. 2006) & $\mathrm{Tp} C \mathrm{x}$ & $=$ levels \\
\hline AchR ( $\alpha 4$ subunit) & (Gotti et al. 2006) & $\mathrm{Cb} \mathrm{Cx}, \mathrm{Str}$ & $\downarrow$ levels \\
\hline AchR ( $\alpha 5$ subunit) & (Gotti et al. 2006) & Str, Tp Cx & $=$ levels \\
\hline AchR ( $\alpha 6$ subunit) & (Gotti et al. 2006) & $\mathrm{Tp} C \mathrm{x}$ & $=$ levels \\
\hline AchR ( $\alpha 6$ subunit) & (Gotti et al. 2006) & Str & $\downarrow$ levels \\
\hline AchR ( $\alpha 7$-subunit) & (Burghaus et al. 2003) & $\mathrm{CbCx}$ & $\downarrow$ levels \\
\hline AchR ( $\alpha 7$-subunit) & (Banerjee et al. 2000) & $\mathrm{Tp} C \mathrm{x}$ & $\downarrow$ nb of neurons \\
\hline AchR ( $\beta 2$ subunit) & (Gotti et al. 2006) & $\mathrm{Tp} C \mathrm{x}$ & $=$ levels \\
\hline $\operatorname{AchR}(\beta 2$ subunit $)$ & (Gotti et al. 2006) & Str & $\downarrow$ levels \\
\hline
\end{tabular}




\begin{tabular}{|c|c|c|c|}
\hline AchR ( $\beta 3$ subunit) & (Gotti et al. 2006) & $\mathrm{Tp} C \mathrm{x}$ & $=$ levels \\
\hline AchR ( $\beta 3$ subunit) & (Gotti et al. 2006) & Str & $\downarrow$ levels \\
\hline $\operatorname{AchR}(\beta 4$ subunit) & (Gotti et al. 2006) & Str, Tp Cx & $=$ levels \\
\hline $\begin{array}{l}\text { Angiotensin II } \\
\text { receptor }\end{array}$ & (Allen et al. 1992) & $\mathrm{Ca}, \mathrm{Pu}, \mathrm{SN}$ & $\downarrow$ levels \\
\hline Arginine vasopressin & (Leake et al. 1991) & Oc Cx, Tp Cx & $=$ levels \\
\hline Asparagine & (Gerlach et al. 1996) & $\begin{array}{l}\mathrm{Ca}, \mathrm{Fr} \mathrm{Cx}, \mathrm{GP}, \mathrm{Nacc} \\
\mathrm{Pu}, \mathrm{SN}, \mathrm{STN}, \mathrm{Th}\end{array}$ & $=$ levels \\
\hline Aspartate & (Gerlach et al. 1996) & $\begin{array}{l}\mathrm{Ca}, \mathrm{Fr} \mathrm{Cx}, \mathrm{GP}, \mathrm{Nacc}, \\
\mathrm{Pu}, \mathrm{SN}, \mathrm{STN}, \mathrm{Th}\end{array}$ & $=$ levels \\
\hline Beta-arrestin & (Price et al. 2010) & $\mathrm{Ca}, \mathrm{Fr} \mathrm{Cx}, \mathrm{Hp}$ & $\uparrow$ cytosolic levels \\
\hline ChAT & $\begin{array}{l}\text { (Rinne et al. 1989),(Mattila et al. 2001), } \\
\text { (Gotti et al. 2006) }\end{array}$ & $\begin{array}{l}\text { Fr Cx, Hp, NBM, pFr } \\
\text { Cx, Tp Cx }\end{array}$ & $\downarrow$ activity \\
\hline ChAT & (Xuereb et al. 1990), (Gotti et al. 2006) & STN, Str, Th & = activity \\
\hline $\mathrm{CRH}$ & (Leake et al. 1991) & Oc Cx, Tp Cx & $=$ levels \\
\hline D1R & $\begin{array}{l}\text { (Mattila et al. 2001),(Piggott et al. } \\
\text { 1999),(Griffiths et al. 1994), }\end{array}$ & $\mathrm{Ca}, \mathrm{Nacc}, \mathrm{Pu}$ & $=$ levels and density \\
\hline $\mathrm{D} 2 \mathrm{R}$ & (Griffiths et al. 1994), (Varani et al. 2010) & $\mathrm{Ca}, \mathrm{Pu}$ & $=$ density \\
\hline $\mathrm{D} 2 \mathrm{R}$ & (Piggott et al. 2007) & Th & $\uparrow$ levels \\
\hline $\mathrm{D} 2 \mathrm{R}$ & (Mattila et al. 2001) & $\mathrm{Ca}, \mathrm{Pu}$ & $=$ levels \\
\hline D2R & (Piggott et al. 1999) & $\mathrm{Ca}, \mathrm{Nacc}, \mathrm{Pu}$ & $\uparrow$ density \\
\hline $\mathrm{D} 2 \mathrm{R}$ & (Ahlskog et al. 1991) & $\mathrm{Pu}$ & $\downarrow$ density \\
\hline D3R & (Piggott et al. 1999) & $\mathrm{Ca}, \mathrm{Nacc}, \mathrm{Pu}$ & $=$ density \\
\hline DAT & (Ryoo et al. 1998), (Güzey et al. 2012) & $\mathrm{Ca}, \mathrm{Pu}$ & $\downarrow$ levels \\
\hline DOPAC & (Gerlach et al. 1996) & $\begin{array}{l}\text { GP, STN, SN, Fr Cx, } \\
\text { Th }\end{array}$ & $=$ levels \\
\hline DOPAC & (Gerlach et al. 1996) & $\mathrm{Ca}, \mathrm{Fr} \mathrm{Cx}, \mathrm{Nacc}, \mathrm{Pu}$ & $\downarrow$ levels \\
\hline Dopamine & (Gerlach et al. 1996) & STN, Th, SN, & $=$ levels \\
\hline Dopamine & (Gerlach et al. 1996) & $\mathrm{Ca}, \mathrm{GP}, \mathrm{Nacc}, \mathrm{Pu}$ & $\downarrow$ levels \\
\hline EAAC1 & (Duerson et al. 2009) & SN & $=$ levels \\
\hline GABA & (Gerlach et al. 1996) & Str, Th & $\downarrow$ levels \\
\hline GABA & (Gerlach et al. 1996) & $\begin{array}{l}\mathrm{Ca}, \mathrm{GP}, \mathrm{Nacc}, \mathrm{Pu}, \\
\text { SN, STN }\end{array}$ & $=$ levels \\
\hline GABA receptor & (Lloyd et al. 1977) & SN & $\downarrow$ density \\
\hline GABA receptor & (Lloyd et al. 1977) & GP, Th & $=$ density \\
\hline $\mathrm{GABA}_{\mathrm{A}} \mathrm{R}$ & (Griffiths et al. 1994) & $\mathrm{Ca}, \mathrm{GP}, \mathrm{Pu}$ & $\downarrow$ density \\
\hline Glutamate & (Gerlach et al. 1996) & $\begin{array}{l}\mathrm{Ca}, \text { Fr Cx, GP, Nacc, } \\
\mathrm{Pu}, \mathrm{SN}, \mathrm{STN}, \mathrm{Th}\end{array}$ & $=$ levels \\
\hline Glutamine & (Gerlach et al. 1996) & $\mathrm{Ca}, \mathrm{GP}, \mathrm{Th}$ & $\uparrow$ levels \\
\hline Glutamine & (Gerlach et al. 1996) & $\begin{array}{l}\text { Fr Cx, Nacc, Pu, SN, } \\
\text { STN }\end{array}$ & $=$ levels \\
\hline Glycine receptor & (de Montis et al. 1982) & SN & $\downarrow$ density \\
\hline Histamine-2 receptor & (Martinez-Mir et al. 1993) & Str & $=$ levels \\
\hline Histamine-3 receptor & (Goodchild et al. 1999) & $\begin{array}{l}\mathrm{Ca}, \mathrm{Cx}, \mathrm{GP}, \mathrm{Nacc}, \mathrm{Pu}, \\
\mathrm{SN}\end{array}$ & $=$ levels \\
\hline HVA & (Gerlach et al. 1996) & $\mathrm{Ca}, \mathrm{Nacc}, \mathrm{Pu}$ & $\downarrow$ levels \\
\hline HVA & (Gerlach et al. 1996) & $\begin{array}{l}\text { Fr Cx, GP, SN, STN, } \\
\text { Th }\end{array}$ & $=$ levels \\
\hline MAO & (Gargalidis-Moudanos et al. 1997) & $\mathrm{Pu}$ & = activity \\
\hline MAOB & (Gargalidis-Moudanos et al. 1997) & $\mathrm{Cb} \mathrm{Cx}$ & = activity \\
\hline
\end{tabular}




\begin{tabular}{|c|c|c|c|}
\hline \multirow{2}{*}{$\begin{array}{l}\text { mGluR5 } \\
\text { mGluR5 }\end{array}$} & (Price et al. 2010) & $\mathrm{Ca}, \mathrm{Fr} \mathrm{Cx}$ & $\uparrow$ levels \\
\hline & (Price et al. 2010) & $\mathrm{Hp}$ & $=$ levels \\
\hline Muscarinic receptor & (Ahlskog et al. 1991) & $\mathrm{Pu}$ & $\downarrow$ density \\
\hline Muscarinic receptor & (Griffiths et al. 1994) & $\mathrm{Pu}$ & $\uparrow$ density \\
\hline Muscarinic receptor & (Griffiths et al. 1994) & $\mathrm{Ca}$ & $=$ density \\
\hline $\begin{array}{l}\text { Muscarinic receptor } \\
\text { M1 }\end{array}$ & (Rinne et al. 1989) & Fr Cx, Hp, Tp Cx & $=$ levels \\
\hline $\begin{array}{l}\text { Muscarinic receptor } \\
\text { M2 }\end{array}$ & (Rinne et al. 1989) & Fr Cx, Tp Cx & $\uparrow$ levels \\
\hline $\begin{array}{l}\text { Muscarinic receptor } \\
\text { M2 }\end{array}$ & (Rinne et al. 1989) & $\mathrm{Hp}$ & $=$ levels \\
\hline Neuromelanin & (Halliday et al. 2006) & $\mathrm{SN}$ & $\begin{array}{l}\uparrow \text { levels in } \mathrm{TH} \\
\text { neurons }\end{array}$ \\
\hline Neurotensin receptor & (Uhl et al. 1986) & $\mathrm{Mb}$ & $\downarrow$ density \\
\hline NMDA Receptor & (Gerlach et al. 1996) & $\mathrm{Ca}$ & $\downarrow$ density \\
\hline NMDA Receptor & (Gerlach et al. 1996) & $\begin{array}{l}\text { Fr Cx, GP, Nacc, Pu, } \\
\text { SN, STN, Th }\end{array}$ & $=$ density \\
\hline NQO1 & (van Muiswinkel et al. 2004) & $\mathrm{SN}$ & $\begin{array}{l}\uparrow \text { levels in neurons } \\
\text { and astrocytes }\end{array}$ \\
\hline Opiate receptor $(\mu)$ & (Uhl et al. 1986) & $\mathrm{Mb}$ & $\downarrow$ density \\
\hline Opiate receptor $(\kappa)$ & (Uhl et al. 1986) & $\mathrm{Mb}$ & $\downarrow$ density \\
\hline Serotonin transporter & (Güzey et al. 2012) & $\mathrm{Ca}, \mathrm{Cg}$ Gy & $\downarrow$ density \\
\hline Serotonin-1 receptor & (Press and Waeber 1989) & $\mathrm{Cx}, \mathrm{Nacc}, \mathrm{SN}$ & $=$ density \\
\hline Somatostatin & (Leake et al. 1991) & Oc Cx, Tp Cx & $=$ levels \\
\hline Somatostatin receptor & (Uhl et al. 1986) & $\mathrm{Mb}$ & $\downarrow$ density \\
\hline $\mathrm{TH}$ & (Kastner et al. 1993) & $\mathrm{SN}$ & $\downarrow$ level per neuron \\
\hline $\mathrm{TH}$ & (Ryoo et al. 1998) & $\mathrm{Pu}$ & $\downarrow$ levels \\
\hline $\mathrm{TH}$ & (Ryoo et al. 1998) & $\mathrm{Ca}, \mathrm{GP}$ & $=$ levels \\
\hline VMAT2 & (Thibaut et al. 1995) & $\mathrm{LC}, \mathrm{Ra}, \mathrm{SN}$ & $\downarrow$ density \\
\hline VMAT2 & (Miller et al. 1999) & $\mathrm{Ca}, \mathrm{Nacc}, \mathrm{Pu}$ & $\downarrow$ levels \\
\hline \multicolumn{4}{|l|}{ Neurotrophic factors } \\
\hline $\mathrm{BDNF}$ & (Chauhan et al. 2001),(Mogi et al. 1999) & Str, SN & $\downarrow$ levels \\
\hline BDNF & (Mogi et al. 1999) & $\mathrm{Cb}, \mathrm{Fr} \mathrm{Cx}$ & $=$ levels \\
\hline BDNF & (Imamura et al. 2005) & $\mathrm{Hp}$ & $\downarrow$ levels \\
\hline BDNF & (Parain et al. 1999) & SN & $\begin{array}{l}\downarrow \mathrm{nb} \text { of expressing } \\
\text { TH neurons }\end{array}$ \\
\hline BDNF & ott et al. 2002) & SN & $\begin{array}{l}=\text { levels in } \mathrm{TH} \\
\text { neurons }\end{array}$ \\
\hline BDNF & ott et al. 2002) & SN & $\begin{array}{l}\uparrow \mathrm{nb} \text { of expressing } \\
\text { astrocytes }\end{array}$ \\
\hline bFGF & oyama et al. 1994) & SN & $\begin{array}{l}\downarrow \text { nb of expressing } \\
\text { TH neurons }\end{array}$ \\
\hline bFGF & gi et al. 1996b) & $\mathrm{Ca}, \mathrm{Cx}, \mathrm{Pu}$ & $=$ levels \\
\hline CNTF & auhan et al. 2001) & SN & $\downarrow$ levels \\
\hline $\mathrm{CRH}$ & ogendijk et al. 1998) & PVN & $\begin{array}{l}=\text { nb of expressing } \\
\text { neurons }\end{array}$ \\
\hline EGF & gi et al. 1999) & $\mathrm{Ca}$ & $\uparrow$ levels \\
\hline EGF & gi et al. 1999) & $\mathrm{Cb} \mathrm{Cx}, \mathrm{Pu}$ & $=$ levels \\
\hline EGF & akura et al. 2005) & $\mathrm{pFr} C \mathrm{x}, \mathrm{Str}$ & $\downarrow$ levels \\
\hline ErbB 1 & akura et al. 2005) & pFr Cx, Str & $\downarrow$ levels \\
\hline
\end{tabular}




\begin{tabular}{|c|c|c|c|}
\hline ErbB2 & (Iwakura et al. 2005) & $\mathrm{pFr} C \mathrm{x}, \mathrm{Str}$ & $\downarrow$ levels \\
\hline ErbB3 & (Iwakura et al. 2005) & $\mathrm{pFr} \mathrm{Cx}, \mathrm{Str}$ & $=$ levels \\
\hline ErbB4 & (Iwakura et al. 2005) & pFr Cx, Str & $=$ levels \\
\hline ErbB4 & (Depboylu et al. 2012) & SN & $\begin{array}{l}\uparrow \text { proportion of } \\
\text { expressing } \mathrm{TH} \\
\text { neurons }\end{array}$ \\
\hline FGFR1 & (Walker et al. 1998b) & SN & $\begin{array}{l}=\text { levels in TH } \\
\text { neurons }\end{array}$ \\
\hline GDNF & (Mogi et al. 2001),(Chauhan et al. 2001) & $\mathrm{Pu}, \mathrm{SN}$ & $\downarrow$ levels \\
\hline GDNF & (Mogi et al. 2001) & $\mathrm{Ca}$ & $\uparrow$ levels \\
\hline GDNF & (Mogi et al. 2001) & $\mathrm{Cb}, \mathrm{Fr} \mathrm{Cx}$ & $=$ levels \\
\hline HB-EGF & (Iwakura et al. 2005) & pFr Cx, Str & $=$ levels \\
\hline Insulin receptor & (Moroo et al. 1994) & PPN, SN & $\downarrow$ levels \\
\hline NGF & (Mogi et al. 1999) & $\mathrm{SN}$ & $\downarrow$ levels \\
\hline NGF & (Chauhan et al. 2001) & SN & $=$ levels \\
\hline NT-3 & (Chauhan et al. 2001),(Knott et al. 2002) & SN, Str & $=$ levels \\
\hline NT-4 & (Chauhan et al. 2001) & SN & $=$ levels \\
\hline Ret & (Decressac et al. 2012) & SN & $\begin{array}{l}\downarrow \text { levels in TH } \\
\text { neurons }\end{array}$ \\
\hline Ret & (Walker et al. 1998a) & SN & $=$ levels \\
\hline TGF $\alpha$ & (Mogi et al. 1995) & $\mathrm{Ca}, \mathrm{Pu}$ & $\uparrow$ levels \\
\hline TGF $\alpha$ & (Iwakura et al. 2005),(Mogi et al. 1995) & $\mathrm{Cb} \mathrm{Cx}, \mathrm{pFr} \mathrm{Cx}, \mathrm{Str}$ & $=$ levels \\
\hline TGF- $\beta 1$ & (Mogi et al. 1995) & $\mathrm{Ca}, \mathrm{Pu}$ & $\uparrow$ levels \\
\hline TGF- $\beta 1$ & (Mogi et al. 1995) & $\mathrm{Cb} \mathrm{Cx}$ & $=$ levels \\
\hline TrkB & (Knott et al. 2002) & $\mathrm{SN}, \mathrm{Str}$ & $=$ levels \\
\hline TrkC & (Knott et al. 2002) & SN, Str & $=$ levels \\
\hline
\end{tabular}


Table 2. PD-linked genes changes observed in the human parkinsonian brain at the protein level. Legend: see Table 1.

\begin{tabular}{|c|c|c|c|}
\hline Protein & Ref & Structure & Observation in PD \\
\hline AF6 & (Haskin et al. 2013) & Str, SN & $\downarrow$ levels \\
\hline AIMP2 & (Imam et al. 2011),(Ko et al. 2010) & SN, Str & $\uparrow$ levels \\
\hline $\mathrm{c}-\mathrm{Abl}$ & (Mahul-Mellier et al. 2014) & $\mathrm{Cg} C \mathrm{x}$ & $\uparrow$ levels \\
\hline $\begin{array}{l}\text { c-Abl (phosphorylated at } \\
\text { Y245) }\end{array}$ & (Imam et al. 2011),(Ko et al. 2010) & Str & $\uparrow$ levels \\
\hline $\begin{array}{l}\text { c-Abl (phosphorylated at } \\
\text { Y245) }\end{array}$ & (Imam et al. 2011),(Ko et al. 2010) & $\mathrm{Cx}, \mathrm{SN}$ & $=$ levels \\
\hline DJ-1 & (Bandopadhyay et al. 2004) & Fr Cx & $=$ levels \\
\hline DJ-1 (oxidized) & (Saito et al. 2014) & Str, SN & $\uparrow$ levels \\
\hline $\begin{array}{l}\text { DJ-1 (S-nitrosylated)/ DJ-1 } \\
\text { (total) }\end{array}$ & (Choi et al. 2014) & Fr Cx & $\downarrow$ ratio \\
\hline Dnmt1 (cytoplasm) & (Desplats et al. 2011) & $\mathrm{Cx}$ & $\uparrow$ levels \\
\hline Dnmt1 (nuclear) & (Desplats et al. 2011) & $\mathrm{Cx}$ & $\downarrow$ levels \\
\hline FBP1 & (Imam et al. 2011),(Ko et al. 2010) & $\mathrm{SN}, \mathrm{Str}$ & $\uparrow$ levels \\
\hline GRK5 & (Arawaka et al. 2006) & SN & $=$ levels \\
\hline Jtv-1 & (Kurup et al. 2015) & Str & $\uparrow$ levels \\
\hline LRRK2 & (Guerreiro et al. 2013) & $\begin{array}{l}\mathrm{Ag}, \mathrm{Cg} \mathrm{Cx}, \mathrm{Fr} \\
\mathrm{Cx}\end{array}$ & $\uparrow$ levels \\
\hline MMP3 & (Choi et al. 2011) & SN & $\uparrow$ levels \\
\hline NAC1 & (Korutla et al. 2014) & SN & $\begin{array}{l}\text { aggregates with parkin in } \\
\text { TH neurons }\end{array}$ \\
\hline Parkin (aggregated) & (LaVoie et al. 2005) & $\mathrm{Ca}, \mathrm{Pu}$ & $\uparrow$ levels \\
\hline $\begin{array}{l}\text { Parkin (phosphorylated at } \\
\text { S101) }\end{array}$ & (Rubio de la Torre et al. 2009) & $\mathrm{Ca}$ & $\uparrow$ levels \\
\hline $\begin{array}{l}\text { Parkin (phosphorylated at } \\
\text { S101) }\end{array}$ & (Rubio de la Torre et al. 2009) & $\mathrm{Cb}, \mathrm{Cx}$ & $=$ levels \\
\hline Parkin (S-nitrosylated) & (Chung et al. 2004) & $\begin{array}{l}\mathrm{Cg} C \mathrm{Cx}, \mathrm{SN}, \mathrm{Tp} \\
\mathrm{Cx}\end{array}$ & $\uparrow$ levels \\
\hline Parkin (soluble) & (Lonskaya et al. 2013) & Str & $\downarrow$ level \\
\hline Parkin (total) & $\begin{array}{l}\text { (Wills et al. 2010),(Rubio de la } \\
\text { Torre } \text { et al. 2009),(LaVoie } \text { et al. } \\
\text { 2005) }\end{array}$ & $\begin{array}{l}\mathrm{Ca}, \mathrm{Cb}, \mathrm{Cx}, \mathrm{Fr} \\
\mathrm{Gy}, \mathrm{Str}\end{array}$ & $=$ levels \\
\hline $\begin{array}{l}\text { Parkin (tyrosine- } \\
\text { phosphorylated) }\end{array}$ & (Imam et al. 2011),(Ko et al. 2010) & $\mathrm{SN}, \mathrm{Str}$ & $\uparrow$ levels \\
\hline PARIS & (Shin et al. 2011) & SN, Str & $\uparrow$ levels \\
\hline PDCD2-1 & (Fukae et al. 2009) & $\mathrm{Mb}$ & $\uparrow$ levels \\
\hline PINK1 & (Muqit et al. 2006) & $\mathrm{Cb}, \mathrm{SN}$ & $\uparrow$ levels \\
\hline PINK1 & (Muqit et al. 2006) & $\mathrm{Cx}$ & $=$ levels \\
\hline SEPT4 & (Shehadeh et al. 2009) & $\mathrm{Ag}, \mathrm{SN}$ & $\uparrow$ levels \\
\hline SMG1 & (Henderson-Smith et al. 2013) & $\mathrm{Cg} C x$ & $\downarrow$ levels \\
\hline STEP61 & (Kurup et al. 2015) & Str & $\uparrow$ levels \\
\hline Tissue transglutaminase & $\begin{array}{l}\text { (Wilhelmus et al. 2011b),(Citron et } \\
\text { al. 2002),(Andringa } \text { et al. 2004) }\end{array}$ & SN & $\begin{array}{l}\uparrow \text { levels and activity, levels } \\
\text { in TH neurons, nb of } \\
\text { expressing TH neurons }\end{array}$ \\
\hline UCHL-1 & (Barrachina et al. 2006) & SN & $\downarrow$ levels \\
\hline
\end{tabular}




\begin{tabular}{|c|c|c|c|}
\hline UCHL-1 & (Barrachina et al. 2006) & Fr Cx & $=$ levels \\
\hline USP9X & (Rott et al. 2011) & $\mathrm{SN}$ & $\downarrow$ levels \\
\hline VPS35 & (Tsika et al. 2014) & $\mathrm{Ca}, \mathrm{Pu}, \mathrm{Fr} \mathrm{Cx}$ & $=$ levels \\
\hline $\begin{array}{l}\alpha \text {-synuclein (calpain- } \\
\text { cleaved) }\end{array}$ & (Dufty et al. 2007) & SN & $\uparrow$ levels \\
\hline $\begin{array}{l}\alpha \text {-synuclein } \\
\text { (dimer/monomer) }\end{array}$ & (Sharon et al. 2003) & SN & $\uparrow$ ratio \\
\hline$\alpha$-synuclein (insoluble) & (Wills et al. 2010) & Fr Gy, Str & $\uparrow$ levels \\
\hline$\alpha$-synuclein (mitochondria) & (Devi et al. 2008) & SN, Str & $\uparrow$ levels \\
\hline $\begin{array}{l}\alpha \text {-synuclein (modified with } \\
\text { acrolein) }\end{array}$ & (Shamoto-Nagai et al. 2007) & $\mathrm{SN}$ & $\uparrow$ levels \\
\hline$\alpha$-synuclein (nitrated) & (Giasson et al. 2000) & $\mathrm{Cg} \mathrm{Cx}, \mathrm{Am}$ & $\uparrow$ levels \\
\hline $\begin{array}{l}\alpha \text {-synuclein } \\
\text { (phosphorylated at S129) }\end{array}$ & (Mahul-Mellier et al. 2014) & $\mathrm{Cg} \mathrm{Cx}$ & $\uparrow$ levels \\
\hline $\begin{array}{l}\alpha \text {-synuclein } \\
\text { (phosphorylated at Y125) }\end{array}$ & (Mahul-Mellier et al. 2014) & $\mathrm{Cg} C x$ & $=$ levels \\
\hline $\begin{array}{l}\alpha \text {-synuclein } \\
\text { (phosphorylated at Y39) }\end{array}$ & (Mahul-Mellier et al. 2014) & $\mathrm{Cg} C \mathrm{x}$ & $=$ levels \\
\hline$\alpha$-synuclein (soluble) & (Wills et al. 2010) & Fr Gy, Str & $\uparrow$ levels \\
\hline$\alpha$-synuclein (total) & (Westerlund et al. 2008) & $\mathrm{Cb}$ & $\downarrow$ levels \\
\hline
\end{tabular}


Table 3. Calcium and transition metal-related proteins changes observed in the human parkinsonian brain. Legend: see Table 1 .

\begin{tabular}{|c|c|c|c|}
\hline Protein or metal & Ref & Structure & Observation in PD \\
\hline \multicolumn{4}{|l|}{ Transition metals } \\
\hline Al (Total) & (Good et al. 1992) & $\mathrm{SN}$ & $\begin{array}{l}\uparrow \text { levels in } \mathrm{TH} \\
\text { neurons }\end{array}$ \\
\hline Al (Total) & (Hirsch et al. 1991) & $\mathrm{SN}$ & $\uparrow$ levels \\
\hline Ceruloplasmin & (Loeffler et al. 2006) & $\mathrm{Hp}$ & $\uparrow$ levels \\
\hline Ceruloplasmin & (Loeffler et al. 2006) & $\mathrm{Fr} C \mathrm{x}$ & $\downarrow$ levels \\
\hline Ceruloplasmin & (Ayton et al. 2013) & $\mathrm{SN}$ & $\downarrow$ ferroxidase activity \\
\hline Ceruloplasmin & (Ayton et al. 2013), (Loeffler et al. 2006) & $\begin{array}{l}\mathrm{Ca}, \mathrm{Cb}, \mathrm{Fr} \mathrm{Cx} \\
\mathrm{Pu}, \mathrm{SN}\end{array}$ & $=$ levels \\
\hline Ceruloplasmin & (Ayton et al. 2013) & $\mathrm{Fr} C \mathrm{x}$ & = activity \\
\hline CTR1 & (Davies et al. 2014) & $\mathrm{SN}$ & $\downarrow$ levels \\
\hline $\mathrm{Cu}$ (Total) & (Riederer et al. 1989) & $\mathrm{Rp}$ & $\uparrow$ levels \\
\hline $\mathrm{Cu}$ (Total) & (Dexter et al. 1989),(Ayton et al. 2013) & $\mathrm{SN}$ & $\downarrow$ levels \\
\hline $\mathrm{Cu}$ (Total) & $\begin{array}{l}\text { (Dexter et al. 1989),(Ayton et al. } \\
\text { 2013),(Riederer } \text { et al. 1989) }\end{array}$ & $\begin{array}{l}\mathrm{Ca}, \mathrm{Cb}, \mathrm{Cx}, \mathrm{Fr} \\
\mathrm{Cx}, \mathrm{GP}, \mathrm{Pu}, \mathrm{SN}\end{array}$ & $=$ levels \\
\hline DMT1 & (Salazar et al. 2008) & $\mathrm{SN}$ & $\begin{array}{l}\uparrow \text { levels in } \mathrm{TH} \\
\text { neurons }\end{array}$ \\
\hline Fe (Total) & $\begin{array}{l}\text { (Oakley et al. 2007),(Jellinger } \text { et al. } \\
\text { 1992),(Good et al. 1992) } \\
\text { (Dexter } \text { et al. 1989),(Ayton } \text { et al. }\end{array}$ & $\mathrm{SN}$ & $\begin{array}{l}\uparrow \text { levels in } \mathrm{TH} \\
\text { neurons }\end{array}$ \\
\hline Fe (Total) & $\begin{array}{l}\text { 2013),(Hirsch et al. 1991),(Riederer et al. } \\
\text { 1989) }\end{array}$ & $\mathrm{SN}$ & $\uparrow$ levels \\
\hline Fe (Total) & (Dexter et al. 1989) & GP & $\downarrow$ levels \\
\hline Fe (Total) & $\begin{array}{l}\text { (Dexter et al. 1989),(Ayton et al. } \\
\text { 2013),(Riederer et al. 1989) }\end{array}$ & $\begin{array}{l}\mathrm{Ca}, \mathrm{Cb}, \mathrm{Cx}, \mathrm{GP} \\
\mathrm{Hp}, \mathrm{Pu}\end{array}$ & $=$ levels \\
\hline $\mathrm{Fe}^{2+}$ & (Riederer et al. 1989) & $\begin{array}{l}\mathrm{Cx}, \mathrm{GP}, \mathrm{Hp}, \mathrm{Pu} \\
\mathrm{SN}\end{array}$ & $=$ levels \\
\hline $\mathrm{Fe}^{3+}$ & (Riederer et al. 1989) & $\mathrm{SN}$ & $\uparrow$ levels \\
\hline $\mathrm{Fe}^{3+}$ & (Riederer et al. 1989) & $\mathrm{Cx}, \mathrm{GP}, \mathrm{Hp}, \mathrm{Pu}$ & $=$ levels \\
\hline Ferritin & (Riederer et al. 1989) & $\mathrm{SN}$ & $\uparrow$ levels \\
\hline Ferritin & (Riederer et al. 1989) & $\mathrm{Pu}$ & $=$ levels \\
\hline $\begin{array}{l}\text { Ferritin }(\mathrm{H}- \\
\text { Chain) }\end{array}$ & (Galazka-Friedman et al. 2004) & $\mathrm{SN}$ & $=$ levels \\
\hline $\begin{array}{l}\text { Ferritin (L- } \\
\text { Chain) }\end{array}$ & (Galazka-Friedman et al. 2004) & $\mathrm{SN}$ & $\downarrow$ levels \\
\hline Ferroportin & (Visanji et al. 2013) & $\mathrm{SN}$ & $\uparrow$ levels \\
\hline Lactoferrin & $\begin{array}{l}\text { (Rousseau et al. 2013),(Leveugle et al. } \\
\text { 1996) }\end{array}$ & $\mathrm{SN}$ & $\begin{array}{l}\uparrow \text { levels in } \mathrm{TH} \\
\text { neurons }\end{array}$ \\
\hline $\begin{array}{l}\text { Lactoferrin } \\
\text { receptor }\end{array}$ & (Faucheux et al. 1995) & $\mathrm{SN}$ & $\begin{array}{l}\uparrow \text { levels in } \mathrm{TH} \\
\text { neurons }\end{array}$ \\
\hline $\begin{array}{l}\text { Metallothionein } \\
1 \text { and } 2\end{array}$ & (Michael et al. 2011) & SN & $\begin{array}{l}\uparrow \mathrm{nb} \text { of expressing } \\
\text { astrocytes }\end{array}$ \\
\hline $\operatorname{Mg}$ (Total) & (Riederer et al. 1989) & $\begin{array}{l}\mathrm{Ca}, \mathrm{GP}, \mathrm{Pu}, \mathrm{Rp} \\
\mathrm{SN}\end{array}$ & $=$ levels \\
\hline Mn (Total) & (Dexter et al. 1989) & $\mathrm{Pu}$ & $\downarrow$ levels \\
\hline Mn (Total) & (Dexter et al. 1989) & $\begin{array}{l}\mathrm{Ca}, \mathrm{Cb}, \mathrm{Cx}, \mathrm{GP} \\
\mathrm{SN}\end{array}$ & $=$ levels \\
\hline
\end{tabular}




\begin{tabular}{|c|c|c|c|}
\hline NDFIP1 & (Howitt et al. 2014) & $\mathrm{SN}$ & $\uparrow$ levels \\
\hline $\mathrm{Pb}$ (Total) & (Dexter et al. 1989) & $\begin{array}{l}\mathrm{Ca}, \mathrm{Cb}, \mathrm{Cx}, \mathrm{GP}, \\
\mathrm{Pu}, \mathrm{SN}\end{array}$ & $=$ levels \\
\hline Transferrin & (Mastroberardino et al. 2009) & $\mathrm{SN}$ & $\uparrow$ levels \\
\hline Transferrin & (Faucheux et al. 1997) & $\mathrm{SN}$ & $\begin{array}{l}\downarrow \text { levels in TH } \\
\text { neurons }\end{array}$ \\
\hline $\begin{array}{l}\text { Transferrin } \\
\text { receptor }\end{array}$ & (Mash et al. 1991) & $\mathrm{Pu}$ & $\downarrow$ levels \\
\hline $\begin{array}{l}\text { Transferrin } \\
\text { receptor }\end{array}$ & (Mash et al. 1991) & $\mathrm{Ca}, \mathrm{GP}$ & $=$ levels \\
\hline Zn (Total) & (Dexter et al. 1989),(Riederer et al. 1989) & $\mathrm{Ca}, \mathrm{Pu}, \mathrm{Rp}, \mathrm{SN}$ & $\uparrow$ levels \\
\hline Zn (Total) & (Dexter et al. 1989),(Riederer et al. 1989) & $\begin{array}{l}\mathrm{Ca}, \mathrm{Cb}, \mathrm{Cx}, \mathrm{GP}, \\
\mathrm{Pu}, \mathrm{SN}\end{array}$ & $=$ levels \\
\hline
\end{tabular}

\begin{tabular}{|c|c|c|c|}
\hline \multicolumn{4}{|c|}{ Calcium and calcium-binding proteins } \\
\hline $\mathrm{Ca}^{2+}($ Total $)$ & (Riederer et al. 1989) & $\begin{array}{l}\mathrm{Ca}, \mathrm{GP}, \mathrm{Pu}, \mathrm{Rp}, \\
\mathrm{SN}\end{array}$ & $=$ levels \\
\hline Calbindin & (Hurley et al. 2013) & NBM, SN & $\begin{array}{l}\downarrow \mathrm{nb} \text { of expressing } \\
\text { cells }\end{array}$ \\
\hline Calbindin & (Hurley et al. 2013) & $\mathrm{Cb} \mathrm{Cx}, \mathrm{LC}$ & $=$ levels \\
\hline $\begin{array}{l}\text { Calcium } \\
\text { channels }\end{array}$ & (Watson et al. 1988) & Str & $=$ levels \\
\hline Calmodulin & (Hurley et al. 2013),(Reynolds et al. 2008) & $\mathrm{Cb} \mathrm{Cx}, \mathrm{LC}, \mathrm{SN}$ & $\begin{array}{l}\downarrow \mathrm{nb} \text { of expressing } \\
\text { cells }\end{array}$ \\
\hline Calmodulin & (Hurley et al. 2013) & $\mathrm{NuBa}$ & $=$ levels \\
\hline Calpain II & (Mouatt-Prigent et al. 1996) & $\mathrm{LC}, \mathrm{SN}$ & $\begin{array}{l}\uparrow \mathrm{nb} \text { of expressing } \\
\text { neurons }\end{array}$ \\
\hline Calpastatin & (Mouatt-Prigent et al. 2000) & $\mathrm{SN}$ & $\downarrow$ nb TH neurons \\
\hline Calreticulin & (Hurley et al. 2013) & LC, NBM, SN & $\begin{array}{l}\downarrow \mathrm{nb} \text { of expressing } \\
\text { cells }\end{array}$ \\
\hline Calreticulin & (Hurley et al. 2013) & $\mathrm{CbCx}$ & $=$ levels \\
\hline Calreticulin & (Wilhelmus et al. 2011b) & $\mathrm{SN}$ & $\begin{array}{l}\uparrow \text { levels in } \mathrm{TH} \\
\text { neurons }\end{array}$ \\
\hline $\mathrm{Ca}_{\mathrm{v}} 1.2$ & (Hurley et al. 2013) & LC, NBM, SN & $\begin{array}{l}\downarrow \mathrm{nb} \text { of expressing } \\
\text { cells }\end{array}$ \\
\hline $\mathrm{Ca}_{\mathrm{v}} 1.2$ & (Hurley et al. 2013) & $\mathrm{CbCx}$ & $=$ levels \\
\hline $\mathrm{Ca}_{\mathrm{v}} 1.3$ & (Hurley et al. 2013) & $\mathrm{Cb} C \mathrm{x}, \mathrm{LC}$ & $\begin{array}{l}\uparrow \mathrm{nb} \text { of expressing } \\
\text { cells }\end{array}$ \\
\hline $\mathrm{Ca}_{\mathrm{v}} 1.3$ & (Hurley et al. 2013) & NBM, SN & $\begin{array}{l}\downarrow \text { nb of expressing } \\
\text { cells }\end{array}$ \\
\hline Lipocortin-1 & (Knott et al. 2000) & $\mathrm{SN}$ & $\begin{array}{l}\uparrow \text { levels in microglial } \\
\text { cells }\end{array}$ \\
\hline Parvalbumin & (Soós et al. 2004) & $\mathrm{SN}$ & $\begin{array}{l}\uparrow \text { levels in } \mathrm{TH} \\
\text { neurons }\end{array}$ \\
\hline PKC & (Tanaka et al. 1993) & $\mathrm{SN}$ & $\downarrow$ levels \\
\hline
\end{tabular}


Table 4. Changes in neuroinflammatory-related proteins observed in the human parkinsonian brain. Legend: see Table 1.

\begin{tabular}{|c|c|c|c|}
\hline Protein & Ref & Structure & Observation in PD \\
\hline $\mathrm{C} 1 \mathrm{q}+$ microglia & (Depboylu et al. 2011) & $\mathrm{SN}$ & $\uparrow \mathrm{nb}$ \\
\hline C9 & (Loeffler et al. 2006) & SN & $=$ levels \\
\hline Caspase-3 (activated) & (Burguillos et al. 2011) & SN & $\uparrow$ levels in microglia \\
\hline Caspase- 8 (activated) & (Burguillos et al. 2011) & $\mathrm{SN}$ & $\uparrow$ levels in microglia \\
\hline CCL5 & (Shimoji et al. 2009) & Str & $\downarrow$ levels \\
\hline CCL5 & (Shimoji et al. 2009) & Fr Cx, SN & $=$ levels \\
\hline CD163 & (Pey et al. 2014) & $\mathrm{LC}, \mathrm{SN}$ & $\begin{array}{l}\uparrow \mathrm{nb} \text { of expressing } \\
\text { microglia }\end{array}$ \\
\hline $\mathrm{CD} 23$ & (Hunot et al. 1999) & $\mathrm{SN}$ & $\uparrow$ levels \\
\hline CD23 & (Hunot et al. 1999) & SN & $\begin{array}{l}\uparrow \mathrm{nb} \text { of expressing } \\
\text { microglia }\end{array}$ \\
\hline $\mathrm{CD} 23$ & (Hunot et al. 1999) & $\mathrm{SN}$ & $\begin{array}{l}\uparrow \mathrm{nb} \text { of expressing } \\
\text { astrocyte }\end{array}$ \\
\hline CD68+ microglia & (Vroon et al. 2007) & OB & $\uparrow \mathrm{nb}$ \\
\hline $\mathrm{CD} 4+\mathrm{T}$ cells & (Brochard et al. 2009) & $\mathrm{SN}$ & $\uparrow \mathrm{nb}$ \\
\hline $\mathrm{CD} 8+\mathrm{T}$ cells & (Brochard et al. 2009) & $\mathrm{SN}$ & $\uparrow \mathrm{nb}$ \\
\hline CR3/43+ microglia & $\begin{array}{l}\text { (Imamura et al. 2003),(Imamura et al. } \\
\text { 2005),(Orr et al. 2005) }\end{array}$ & $\begin{array}{l}\text { Cg Cx, Hp, } \\
\text { Pu,SN }\end{array}$ & $\uparrow \mathrm{nb}$ \\
\hline CXCL12 & (Shimoji et al. 2009) & Str & $\uparrow$ levels \\
\hline CXCL12 & (Shimoji et al. 2009) & Fr Cx, SN & $=$ levels \\
\hline CXCR4 & (Shimoji et al. 2009) & $\mathrm{SN}, \mathrm{Str}$ & $\uparrow$ levels \\
\hline CXCR4 & (Shimoji et al. 2009) & $\mathrm{LC}$ & $=$ levels \\
\hline Cyclooxygenase-2 & (Teismann et al. 2003) & SN & $\uparrow$ levels in TH neurons \\
\hline Cyclooxygenase-2 & (Teismann et al. 2003) & $\mathrm{SN}$ & $\uparrow$ levels \\
\hline GFAP & $\begin{array}{l}\text { (Lastres-Becker et al. 2012),(Mythri } \\
\text { et al. 2011) }\end{array}$ & $\mathrm{Ca}, \mathrm{Fr} \mathrm{Cx}, \mathrm{SN}$ & $\uparrow$ levels \\
\hline GFAP & (Mythri et al. 2011) & $\mathrm{Pu}$ & $=$ levels \\
\hline Glucocorticoid receptors & (Ros-Bernal et al. 2011) & $\mathrm{Pu}$ & $\uparrow$ levels \\
\hline HO-1 & (Schipper et al. 2009) & $\mathrm{SN}$ & $\begin{array}{l}\uparrow \mathrm{nb} \text { of expressing } \\
\text { astrocytes }\end{array}$ \\
\hline Iba1 & (Lastres-Becker et al. 2012) & SN & $\uparrow$ levels \\
\hline $\mathrm{iC} 3 \mathrm{~b}$ & (Loeffler et al. 2006) & $\mathrm{SN}$ & $\begin{array}{l}\uparrow \mathrm{nb} \text { of expressing TH } \\
\text { cells }\end{array}$ \\
\hline ICAM-1+astrocytes & (Miklossy et al. 2006) & SN & $\uparrow \mathrm{nb}$ \\
\hline ICAM-1+ microglia & (Imamura et al. 2003) & $\mathrm{Hp}, \mathrm{Pu}, \mathrm{SN}$ & $\uparrow \mathrm{nb}$ \\
\hline IgG & (Orr et al. 2005) & $\mathrm{SN}$ & $\uparrow$ levels in TH neurons \\
\hline IL-1 $\beta$ & (Mogi et al. 1994a) & $\mathrm{Ca}, \mathrm{Pu}$ & $\uparrow$ levels \\
\hline IL-1 $\beta$ & (Mogi et al. 1994a) & $\mathrm{CbCx}$ & $=$ levels \\
\hline IL-1 $\beta$ & (Hunot et al. 1999) & $\mathrm{SN}$ & $\begin{array}{l}\uparrow \mathrm{nb} \text { of expressing glial } \\
\text { cells }\end{array}$ \\
\hline IL-2 & (Mogi et al. 1996b) & $\mathrm{Ca}, \mathrm{Pu}$ & $\uparrow$ levels \\
\hline IL-2 & (Mogi et al. 1996b) & $\mathrm{Cx}$ & $=$ levels \\
\hline IL-6 & (Mogi et al. 1994a) & $\mathrm{Ca}, \mathrm{Pu}$ & $\uparrow$ levels \\
\hline
\end{tabular}




\begin{tabular}{|c|c|c|c|}
\hline IL-6 & (Mogi et al. 1994a) & $\mathrm{CbCx}$ & $=$ levels \\
\hline iNOS & (Knott et al. 2000) & $\mathrm{SN}$ & $\uparrow$ levels in glial cells \\
\hline Interferon $y$ & (Hunot et al. 1999) & SN & $\begin{array}{l}\uparrow \mathrm{nb} \text { of expressing glial } \\
\text { cells }\end{array}$ \\
\hline Interferon- - & (Mogi et al. 2007) & $\mathrm{Ca}, \mathrm{Pu}, \mathrm{SN}$ & $\uparrow$ levels \\
\hline Interferon- - & (Mogi et al. 2007) & $\mathrm{Cb}, \mathrm{Fr} \mathrm{Cx}$ & $=$ levels \\
\hline Interferon-y receptor & (Hashioka et al. 2009) & $\mathrm{SN}$ & $\uparrow$ levels in astrocytes \\
\hline Ki-M1p+ microglia & (Imamura et al. 2005) & SN & $\uparrow n b$ \\
\hline LFA-1+ leukocyte & (Miklossy et al. 2006) & $\mathrm{SN}$ & $\uparrow \mathrm{nb}$ \\
\hline LFA-1+ microglia & (Miklossy et al. 2006) & $\mathrm{SN}$ & $\uparrow n b$ \\
\hline Lipocortin-1 & (Knott et al. 2000) & SN & $\begin{array}{l}\uparrow \text { levels in microglial } \\
\text { cells }\end{array}$ \\
\hline MFGE8 & (Kinugawa et al. 2013) & SN & $\begin{array}{l}\uparrow \text { expression in } \\
\text { astrocytes }\end{array}$ \\
\hline Myeloperoxidase & (Choi et al. 2005a) & $\mathrm{SN}$ & $\uparrow$ levels in astrocytes \\
\hline NF-кB (nuclear) & (Soós et al. 2004) & $\mathrm{SN}$ & $\begin{array}{l}\uparrow \text { levels in TH neurons } \\
\text { nuclei }\end{array}$ \\
\hline NOS & (Hunot et al. 1996) & SN, VTA & $\begin{array}{l}\uparrow \mathrm{nb} \text { of expressing glial } \\
\text { cells }\end{array}$ \\
\hline NOS & (Hunot et al. 1996) & SN, VTA & $\begin{array}{l}\downarrow \text { nb of expressing } \\
\text { neurons }\end{array}$ \\
\hline RAGE & (Sathe et al. 2012) & $\mathrm{Mb}$ & $=$ levels \\
\hline S100B & (Sathe et al. 2012) & $\mathrm{Mb}$ & $\uparrow$ levels in astrocytes \\
\hline TNF- $\alpha$ & (Hunot et al. 1999) & SN & $\begin{array}{l}\uparrow \mathrm{nb} \text { of expressing glial } \\
\text { cells }\end{array}$ \\
\hline TNF- $\alpha$ & (Mogi et al. 1994b) & $\mathrm{Ca}, \mathrm{Str}$ & $\uparrow$ levels \\
\hline
\end{tabular}


Table 5. Changes in mitochondrial and oxidative stress-related proteins observed in the human parkinsonian brain. Legend: see Table 1.

\begin{tabular}{|c|c|c|c|}
\hline Protein & Ref & Structure & Observation in PD \\
\hline \multicolumn{4}{|c|}{ Mitochondrial abnormalities and energy deficit } \\
\hline 6PGD & (Dunn et al. 2014) & $\mathrm{Cx}, \mathrm{Pu}$ & $\downarrow$ levels and activity \\
\hline AF6 & (Haskin et al. 2013) & SN, Str & $\downarrow$ levels \\
\hline ATP synthase & (Ferrer et al. 2007) & SN & $\downarrow$ levels \\
\hline ATP synthase & (Ferrer et al. 2007) & Fr Cx & $\uparrow$ levels \\
\hline Citrate synthase & (Schapira et al. 1990) & $\begin{array}{l}\mathrm{Ca}, \mathrm{Cb}, \mathrm{Cr} \mathrm{Cx} \\
\mathrm{GP}, \mathrm{SN}\end{array}$ & $=$ activity \\
\hline Complex I & (Moisoi et al. 2009) & $\mathrm{Mb}$ & $\downarrow$ levels \\
\hline Complex I & (Keeney et al. 2006) & Fr Cx & $=$ levels \\
\hline Complex I & (Hattori et al. 1993) & SN & $\begin{array}{l}\downarrow \text { nb of expressing } \\
\text { neurons }\end{array}$ \\
\hline Complex I & $\begin{array}{l}\text { (Navarro et al. 2009),(Schapira et al. } \\
\text { 1990),(Schapira et al. 1989),(Keeney et } \\
\text { al. 2006),(Parker } \text { et al. 2008) }\end{array}$ & Fr Cx, SN & $\downarrow$ activity \\
\hline Complex I & (Mythri et al. 2011),(Schapira et al. 1990) & $\begin{array}{l}\mathrm{Ca}, \mathrm{Cb}, \mathrm{Cr} \mathrm{Cx}, \\
\text { Fr Cx, GP, Pu }\end{array}$ & $=$ activity \\
\hline $\begin{array}{l}\text { Complex I } \\
\text { (carbonylated) }\end{array}$ & (Keeney et al. 2006) & Fr Cx & $\uparrow$ levels \\
\hline Complex II & (Moisoi et al. 2009) & $\mathrm{Mb}$ & $\downarrow$ levels \\
\hline Complex II & (Keeney et al. 2006) & Fr Cx & $=$ levels \\
\hline Complex II & (Navarro et al. 2009),(Parker et al. 2008) & Fr Cx & = activity \\
\hline Complex III & (Keeney et al. 2006) & Fr Cx & $=$ levels \\
\hline Complex III & (Schapira et al. 1990),(Parker et al. 2008) & $\begin{array}{l}\mathrm{Ca}, \mathrm{Cb}, \mathrm{Cr} \mathrm{Cx}, \\
\mathrm{Fr} \mathrm{Cx}, \mathrm{GP}, \mathrm{SN}\end{array}$ & $=$ activity \\
\hline Complex III & (Moisoi et al. 2009) & $\mathrm{Mb}$ & $\downarrow$ levels \\
\hline Complex IV & (Moisoi et al. 2009),(Itoh et al. 1997) & $\mathrm{Mb}, \mathrm{SN}$ & $\downarrow$ levels \\
\hline Complex IV & (Keeney et al. 2006) & Fr Cx & $=$ levels \\
\hline Complex IV & $\begin{array}{l}\text { (Navarro et al. 2009),(Schapira et al. } \\
\text { 1990),(Parker } \text { et al. 2008) }\end{array}$ & $\begin{array}{l}\mathrm{Ca}, \mathrm{Cb}, \mathrm{Cr} \mathrm{Cx}, \\
\text { Fr Cx, GP, SN }\end{array}$ & = activity \\
\hline Complex V & (Keeney et al. 2006) & Fr Cx & $=$ levels \\
\hline Complex V $\alpha$ & (Moisoi et al. 2009) & $\mathrm{Mb}$ & $\downarrow$ levels \\
\hline Cytochrome a & (Navarro et al. 2009) & Fr Cx & $=$ levels \\
\hline Cytochrome b & (Navarro et al. 2009) & Fr Cx & $\uparrow$ levels \\
\hline Cytochrome c & (Navarro et al. 2009) & Fr Cx & $\uparrow$ levels \\
\hline $\begin{array}{l}\text { DNA damage } \\
\text { (mitochondria) }\end{array}$ & (Sanders et al. 2014) & SN & $\uparrow \mathrm{nb}$ in $\mathrm{TH}$ neurons \\
\hline $\begin{array}{l}\text { DNA deletion } \\
\text { (mitochondria) }\end{array}$ & (Bender et al. 2006) & SN & $\uparrow$ levels \\
\hline $\begin{array}{l}\text { DNA deletion } \\
\text { (mitochondria) }\end{array}$ & (Bender et al. 2006) & $\mathrm{Hp}$ & $=$ levels \\
\hline $\begin{array}{l}\text { DNA mutation } \\
\text { (mitochondria) }\end{array}$ & (Lin et al. 2013) & SN & $\uparrow \mathrm{nb}$ in neurons \\
\hline G6PD & (Dunn et al. 2014) & $\mathrm{Cx}, \mathrm{Pu}$ & $\downarrow$ levels and activity \\
\hline $\begin{array}{l}\text { Hemoglobin (alpha and } \\
\text { beta) }\end{array}$ & (Shephard et al. 2014) & SN & $\downarrow$ levels \\
\hline
\end{tabular}




\begin{tabular}{|c|c|c|c|}
\hline HtrA2 (P-S142) & (Plun-Favreau et al. 2007) & $\mathrm{Ca}$ & $\uparrow$ levels \\
\hline $\begin{array}{l}\text { mitochondrial } \\
\text { oxidative damage }\end{array}$ & (Navarro et al. 2009) & Fr Cx & $\uparrow$ levels \\
\hline $\begin{array}{l}\text { mitochondrial oxygen } \\
\text { uptake }\end{array}$ & (Navarro et al. 2009) & Fr Cx & $\downarrow$ levels \\
\hline NADPH production & (Dunn et al. 2014) & $\mathrm{Cx}, \mathrm{Pu}$ & $\uparrow$ levels \\
\hline ND6 & (She et al. 2011) & Str & $\downarrow$ mitochondrial levels \\
\hline $\begin{array}{l}\text { Nicotinamide } \mathrm{N} \text { - } \\
\text { methyltransferase }\end{array}$ & (Parsons et al. 2003) & $\mathrm{Ca}, \mathrm{Cb}$ & $\uparrow$ levels and activity \\
\hline NOS (mitochondrial) & (Navarro et al. 2009) & Fr Cx & $\uparrow$ activity \\
\hline oxygen uptake & (Navarro et al. 2009) & Fr Cx & $\downarrow$ levels \\
\hline Prohibitin & (Ferrer et al. 2007) & $\mathrm{SN}$ & $\downarrow$ levels \\
\hline Prohibitin & (Ferrer et al. 2007) & Fr Cx & $\uparrow$ levels \\
\hline TOM20 & (Bender et al. 2013) & $\mathrm{Mb}$ & $=$ levels \\
\hline TOM40 & (Bender et al. 2013) & $\mathrm{Mb}$ & $\downarrow$ levels \\
\hline VDAC1 & (Chu et al. 2014) & SN & $\begin{array}{l}\downarrow \text { nb of expressing TH } \\
\text { neurons }\end{array}$ \\
\hline $\begin{array}{l}\alpha \text {-ketoglutarate } \\
\text { dehydrogenase }\end{array}$ & (Mizuno et al. 1994) & SN & $\downarrow$ levels \\
\hline \multicolumn{4}{|l|}{ Oxidative stress } \\
\hline 4-hydroxynonenal & (Yoritaka et al. 1996) & SN & $\uparrow \mathrm{nb}$ of reactive cells \\
\hline Ascorbic acid (total) & (Riederer et al. 1989) & $\begin{array}{l}\mathrm{Ca}, \mathrm{GP}, \mathrm{Pu}, \mathrm{Ra}, \\
\mathrm{SN}\end{array}$ & $=$ levels \\
\hline $\begin{array}{l}\text { ATM (phosphorylated } \\
\text { at S1981) }\end{array}$ & (Camins et al. 2010) & $\mathrm{Cg} \mathrm{Cx}$ & $\uparrow$ levels \\
\hline Biliverdin reductase & (Reynolds et al. 2008) & $\mathrm{SN}$ & $\uparrow$ levels \\
\hline Catalase & (Ambani et al. 1975) & $\mathrm{SN}, \mathrm{Str}$ & $\downarrow$ activity \\
\hline Catalase & (Mythri et al. 2011) & $\mathrm{Ca}, \mathrm{Fr} \mathrm{Cx}, \mathrm{Pu}$ & $=$ activity \\
\hline Creatine kinase & (Aksenova et al. 1999) & Fr Cx & $=$ activity \\
\hline DNA polymerase $\delta$ & (Camins et al. 2010) & $\mathrm{Cg} C \mathrm{x}$ & $\uparrow$ levels \\
\hline $\begin{array}{l}\mathrm{\gamma} \text {-glutamyl cysteine } \\
\text { ligase }(\mathrm{\gamma}-\mathrm{GCL})\end{array}$ & (Mythri et al. 2011) & $\mathrm{Ca}, \mathrm{Fr} \mathrm{Cx}, \mathrm{Pu}$ & $=$ activity \\
\hline $\begin{array}{l}\mathrm{\gamma} \text {-glutamyl } \\
\text { transpeptidase }(\mathrm{\gamma GT})\end{array}$ & (Mythri et al. 2011) & $\mathrm{Ca}, \mathrm{Fr} \mathrm{Cx}, \mathrm{Pu}$ & $\downarrow$ activity \\
\hline $\begin{array}{l}\text { y-glutamylcysteine } \\
\text { synthetase }\end{array}$ & (Sian et al. 1994) & $\begin{array}{l}\mathrm{Ca}, \mathrm{Cr} \mathrm{Cx}, \mathrm{GP}, \\
\mathrm{Pu}, \mathrm{SN}\end{array}$ & $=$ activity \\
\hline $\begin{array}{l}\gamma^{-} \\
\text {glutamyltranspeptidase }\end{array}$ & (Sian et al. 1994) & $\begin{array}{l}\mathrm{Ca}, \mathrm{Cr} \mathrm{Cx}, \mathrm{GP}, \\
\mathrm{Pu}, \mathrm{SN}\end{array}$ & $=$ activity \\
\hline $\begin{array}{l}\text { 8-H2AX } \\
\text { (phosphorylated) }\end{array}$ & (Camins et al. 2010) & $\mathrm{Cg} C \mathrm{x}$ & $\uparrow$ levels \\
\hline Glutathione (oxidized) & (Sian et al. 1994) & $\mathrm{Cr} \mathrm{Cx}, \mathrm{Pu}, \mathrm{SN}$ & $=$ levels \\
\hline Glutathione (oxidized) & (Sofic et al. 1992) & SN & $\downarrow$ levels \\
\hline Glutathione (reduced) & (Pearce et al. 1997) & $\mathrm{SN}$ & $\downarrow$ levels in TH neurons \\
\hline Glutathione (reduced) & (Sian et al. 1994) & $\mathrm{SN}$ & $\downarrow$ levels \\
\hline Glutathione (reduced) & (Sian et al. 1994) & $\mathrm{Cr} \mathrm{Cx}, \mathrm{Pu}, \mathrm{SN}$ & $=$ levels \\
\hline Glutathione (reduced) & (Mythri et al. 2011) & $\mathrm{Ca}, \mathrm{Fr} \mathrm{Cx}, \mathrm{Pu}$ & $\uparrow$ activity \\
\hline $\begin{array}{l}\text { Glutathione Peroxidase } \\
\text { (GPx) }\end{array}$ & (Power et al. 2002) & Fr Cx & $\begin{array}{l}\uparrow \mathrm{nb} \text { of expressing } \\
\text { astrocytes }\end{array}$ \\
\hline $\begin{array}{l}\text { Glutathione Peroxidase } \\
\text { (GPx) }\end{array}$ & (Mythri et al. 2011),(Sian et al. 1994) & $\begin{array}{l}\mathrm{Ca}, \mathrm{Cr} \mathrm{Cx}, \mathrm{Fr} \\
\mathrm{Cx}, \mathrm{GP}, \mathrm{Pu}, \mathrm{SN}\end{array}$ & = activity \\
\hline $\begin{array}{l}\text { Glutathione Peroxidase } \\
\text { (GPx) }\end{array}$ & (Mythri et al. 2011) & $\mathrm{Ca}, \mathrm{Pu}$ & $\uparrow$ activity \\
\hline
\end{tabular}




\begin{tabular}{|c|c|c|c|}
\hline $\begin{array}{l}\text { Glutathione Peroxidase } \\
(\mathrm{GPx})\end{array}$ & (Power et al. 2002) & Cg Gy, Fr Gy & $\uparrow$ levels in microglia \\
\hline $\begin{array}{l}\text { Glutathione reductase } \\
\text { (GR) }\end{array}$ & (Mythri et al. 2011) & $\mathrm{Ca}, \mathrm{Fr} \mathrm{Cx}, \mathrm{Pu}$ & $=$ activity \\
\hline $\begin{array}{l}\text { Glutathione-S- } \\
\text { tranferase (GST) }\end{array}$ & (Mythri et al. 2011) & $\mathrm{Ca}, \mathrm{Fr} \mathrm{Cx}, \mathrm{Pu}$ & $=$ activity \\
\hline $\begin{array}{l}\text { Glutathione-S- } \\
\text { tranferase (GST) }\end{array}$ & (Reynolds et al. 2008) & SN & $\downarrow$ levels \\
\hline Gluthatione transferase & (Sian et al. 1994) & $\begin{array}{l}\mathrm{Ca}, \mathrm{Cr} \mathrm{Cx}, \mathrm{GP} \\
\mathrm{Pu}, \mathrm{SN}\end{array}$ & $=$ activity \\
\hline HO1 & (Schipper 2004) & SN & $\begin{array}{l}\uparrow \mathrm{nb} \text { of expressing } \\
\text { astrocytes }\end{array}$ \\
\hline $\mathrm{HO} 1$ & (Lastres-Becker et al. 2012) & SN & $\uparrow$ levels \\
\hline Lipid peroxydation & (Mythri et al. 2011) & Fr Cx & $\uparrow$ levels \\
\hline Lipid peroxydation & (Mythri et al. 2011) & $\mathrm{Ca}, \mathrm{Pu}$ & $\downarrow$ levels \\
\hline $\begin{array}{l}\text { Mitochondrial } \\
\text { oxidative damage }\end{array}$ & (Navarro et al. 2009) & Fr Cx & $\uparrow$ levels \\
\hline Mitochondrial proteins & (Navarro et al. 2009) & Fr Cx & $\uparrow$ levels \\
\hline MTH1 & (Nakabeppu et al. 2007) & SN & $\uparrow$ levels \\
\hline MTH1 & (Shimura-Miura et al. 1999) & SN & $\uparrow$ levels in mitochondria \\
\hline MUTYH & (Nakabeppu et al. 2007) & SN & $\uparrow$ levels \\
\hline MUTYH & (Arai et al. 2006) & SN & $\uparrow$ levels in TH neurons \\
\hline NOX1 & (Choi et al. 2012) & SN & $\uparrow n b$ of $\mathrm{TH}$ neurons \\
\hline $\begin{array}{l}\text { NQO1 (NADPH } \\
\text { quinone } \\
\text { oxidoreductase) }\end{array}$ & (van Muiswinkel et al. 2004) & SN & $\begin{array}{l}\uparrow \text { levels in neurons and } \\
\text { astrocytes }\end{array}$ \\
\hline Nrf2 & (Ramsey et al. 2007) & SN & $\begin{array}{l}\uparrow \text { nuclear and } \\
\downarrow \text { cytoplasmic levels }\end{array}$ \\
\hline Nucleolar integrity & (Rieker et al. 2011) & SN & $\downarrow$ levels in TH neurons \\
\hline OGG1 & (Shimura-Miura et al. 1999) & SN & $\begin{array}{l}\uparrow \text { total and mitochondrial } \\
\text { levels }\end{array}$ \\
\hline Osteopontin & (Maetzler et al. 2007) & SN & $\uparrow$ levels \\
\hline Osteopontin & (Iczkiewicz et al. 2006) & SN & $\downarrow$ nb of positive cells \\
\hline PARP & (Soós et al. 2004) & SN & $\uparrow$ levels in TH nuclei \\
\hline Peroxidase & (Ambani et al. 1975) & SN, Str & $\downarrow$ activity \\
\hline $\begin{array}{l}\text { Peroxiredoxin } 2 \\
\text { (phosphorylated at } \\
\text { T89) }\end{array}$ & (Qu et al. 2007) & SN & $\uparrow$ levels in TH neurons \\
\hline $\begin{array}{l}\text { Peroxiredoxin } 2 \text { (S- } \\
\text { nytrosylated) }\end{array}$ & (Fang et al. 2007) & SN & $\uparrow$ levels \\
\hline $\begin{array}{l}\text { Peroxiredoxin } 3 \\
\text { (phosphorylated) }\end{array}$ & (Angeles et al. 2011) & $\mathrm{Ca}, \mathrm{Cx}$ & $\uparrow$ levels \\
\hline Selenoprotein $\mathrm{P}$ & (Bellinger et al. 2012) & SN & $\begin{array}{l}\downarrow \text { total but } \uparrow \text { levels in } \mathrm{TH} \\
\text { neuron }\end{array}$ \\
\hline Sestrin-2 & (Zhou et al. 2013) & SN & $\uparrow$ levels \\
\hline SOD & (Marttila et al. 1988) & $\begin{array}{l}\text { NBM, SN, Th, } \\
\text { Tp Cx }\end{array}$ & $\uparrow$ activity \\
\hline SOD & (Marttila et al. 1988) & $\begin{array}{l}\mathrm{Ag}, \mathrm{Ca}, \mathrm{Cb} \\
\mathrm{GP}, \mathrm{Pu}\end{array}$ & $=$ levels \\
\hline SOD & (Mythri et al. 2011),(Marttila et al. 1988) & $\mathrm{Ca}, \mathrm{Fr} \mathrm{Cx}$ & = activity \\
\hline SOD & (Mythri et al. 2011) & $\mathrm{Pu}$ & $\downarrow$ activity \\
\hline SOD (cytosolic) & (Radunović et al. 1997) & $\mathrm{Cx}$ & $=$ activity \\
\hline SOD (mitochondrial) & (Radunović et al. 1997) & $\mathrm{Cx}$ & $\uparrow$ activity \\
\hline
\end{tabular}




\begin{tabular}{|c|c|c|c|}
\hline SOD (Mn) & (Shimoda-Matsubayashi et al. 1997) & Fr Cx, Pu, SN & $=$ activity \\
\hline SOD (Mn) & (Navarro et al. 2009) & Frontal cortex & $\uparrow$ levels \\
\hline SOD1 & (Choi et al. 2005b) & $\mathrm{Cg} \mathrm{Cx}$ & $\uparrow$ levels \\
\hline SOD2 & (Ferrer et al. 2007) & SN & $\uparrow$ levels \\
\hline Thioredoxin & (Reynolds et al. 2008) & SN & $=$ levels \\
\hline $\begin{array}{l}\text { Total proteins } \\
\text { (carbonylated) }\end{array}$ & & $\mathrm{Fr} C \mathrm{x}$ & $=$ levels \\
\hline $\begin{array}{l}\text { Total proteins } \\
\text { (carbonylated) }\end{array}$ & (Alam et al. 1997) & $\begin{array}{l}\mathrm{Ca}, \mathrm{Cb}, \mathrm{Fr} \mathrm{Cx} \\
\text { GP, Nacc, Pu, } \\
\text { SN }\end{array}$ & $\uparrow$ levels \\
\hline $\begin{array}{l}\text { Total proteins } \\
\text { (carbonylated) }\end{array}$ & (Aksenova et al. 1999) & $\mathrm{Fr} C \mathrm{x}$ & $=$ levels \\
\hline $\begin{array}{l}\text { Total proteins } \\
\text { (oxidized) }\end{array}$ & (Mythri et al. 2011),(Choi et al. 2005b) & $\mathrm{Ca}, \mathrm{Cg} \mathrm{Cx}$ & $\uparrow$ levels \\
\hline $\begin{array}{l}\text { Total proteins } \\
\text { (oxidized) }\end{array}$ & (Mythri et al. 2011) & $\mathrm{Fr} \mathrm{Cx}, \mathrm{Pu}$ & $=$ levels \\
\hline $\begin{array}{l}\text { Total proteins } \\
\text { (nitrosylated) }\end{array}$ & (Mythri et al. 2011) & $\mathrm{Ca}, \mathrm{Fr} \mathrm{Cx}, \mathrm{Pu}$ & $=$ levels \\
\hline TTRAP (cytoplasmic) & (Vilotti et al. 2012) & SN & $\uparrow$ in TH neurons \\
\hline
\end{tabular}


Table 6. Changes in ubiquitin proteasome system, lysosomal and autophagy proteins observed in the human parkinsonian brain. Legend: see Table 1.

\begin{tabular}{|c|c|c|c|}
\hline Protein & Ref & Structure & Observation in PD \\
\hline \multicolumn{4}{|l|}{ Ubiquitin proteasome system } \\
\hline 19S proteasome & (Wills et al. 2010) & Fr Gy, Str & $=$ levels \\
\hline 20S proteasome & (Wills et al. 2010) & Fr Gy, Str & $\downarrow$ levels \\
\hline 20S proteasome & (Chu et al. 2009) & $\mathrm{SN}$ & $\downarrow$ levels in neurons \\
\hline 20S proteasome ( $\alpha$ subunit) & (McNaught et al. 2003) & $\mathrm{SN}$ & $\downarrow$ levels \\
\hline $20 \mathrm{~S}$ proteasome ( $\alpha 6$ subunit) & (Nakamura et al. 2006) & Str & $\begin{array}{l}\uparrow \text { levels and nuclear } \\
\text { localization }\end{array}$ \\
\hline 20S proteasome ( $\alpha 6$ subunit) & (Nakamura et al. 2006) & $\mathrm{SN}$ & $\uparrow$ levels \\
\hline 20S proteasome & (McNaught and Jenner 2001) & $\mathrm{SN}$ & $\downarrow$ activity \\
\hline 20S proteasome & (McNaught and Jenner 2001) & $\begin{array}{l}\mathrm{Cb}, \mathrm{Fr} \mathrm{Cx}, \mathrm{Hp}, \\
\mathrm{Po}, \mathrm{Str}\end{array}$ & = activity \\
\hline $20 \mathrm{~S} / 26 \mathrm{~S}$ proteasome & (McNaught and Jenner 2001) & $\mathrm{SN}$ & $\downarrow$ activity \\
\hline $20 \mathrm{~S}$ ( $\alpha 4$ subunit) & (Bukhatwa et al. 2010) & $\mathrm{SN}$ & $\begin{array}{l}\downarrow \text { nb of expressing } \\
\text { TH neurons }\end{array}$ \\
\hline $20 \mathrm{~S}$ ( $\alpha 6$ subunit) & (Bukhatwa et al. 2010) & $\mathrm{SN}$ & $\begin{array}{l}\downarrow \text { nb of expressing } \\
\text { TH neurons }\end{array}$ \\
\hline $20 \mathrm{~S}$ ( $\beta 3$ subunit) & (Bukhatwa et al. 2010) & $\mathrm{SN}$ & $=$ levels \\
\hline $20 \mathrm{~S}$ ( $\beta 5$ subunit) & (Bukhatwa et al. 2010) & $\mathrm{SN}$ & $=$ levels \\
\hline $26 \mathrm{~S}$ proteasome & (Wills et al. 2010) & Str & = activity \\
\hline $26 \mathrm{~S}$ proteasome & (Wills et al. 2010) & Fr Gy & $\downarrow$ activity \\
\hline $26 \mathrm{~S} / 20 \mathrm{~S}$ proteasome ( $\alpha$ subunit) & (McNaught et al. 2003) & Fr Cx, Str & $=$ levels \\
\hline $26 \mathrm{~S} / 20 \mathrm{~S}$ proteasome ( $\alpha$ subunit) & (McNaught et al. 2003) & $\mathrm{SN}$ & $\downarrow$ levels \\
\hline $26 \mathrm{~S} / 20 \mathrm{~S}$ proteasome ( $\beta$ subunit) & (McNaught et al. 2003) & Fr Cx, SN, Str & $=$ levels \\
\hline Nedd4 & (Tofaris et al. 2011) & $\mathrm{SN}$ & $\begin{array}{l}\uparrow \text { cytoplasmic levels } \\
\text { in TH neurons }\end{array}$ \\
\hline PA28 & (McNaught et al. 2003) & $\mathrm{FrCx}$ & $\downarrow$ levels \\
\hline PA28 & (McNaught et al. 2003) & $\mathrm{SN}, \mathrm{Str}$ & $=$ levels \\
\hline PA700 & (McNaught et al. 2003) & Fr Cx, SN, Str & $\uparrow$ levels \\
\hline SKP1A & (Mandel et al. 2007) & $\mathrm{SN}$ & $\downarrow$ levels \\
\hline TRIM9 & (Tanji et al. 2010) & $\mathrm{SN}$ & $\downarrow$ levels \\
\hline Ubiquitinated proteins & (Lonskaya et al. 2013) & Str & $\uparrow$ levels \\
\hline USP9X & (Rott et al. 2011) & $\mathrm{SN}$ & $\downarrow$ levels \\
\hline \multicolumn{4}{|l|}{ Lysosome and autophagy } \\
\hline Beclin 1 & (Murphy et al. 2014) & $\mathrm{Cg} C \mathrm{x}$ & $\downarrow$ levels \\
\hline Beclin 1 & (Miki et al. 2015) & $\mathrm{SN}$ & $\uparrow$ levels \\
\hline Beclin 1 (caspase-cleaved) & (Rohn and Catlin 2011) & $\mathrm{SN}$ & $\uparrow$ levels \\
\hline Beclin1 (phosphorylated) & (Miki et al. 2015) & $\mathrm{SN}$ & $=$ levels \\
\hline Cathepsin A & (Murphy et al. 2014) & $\mathrm{Cg} C x$ & $\uparrow$ levels \\
\hline cathepsin B & (Mantle et al. 1995) & Fr Cx & $=$ levels \\
\hline Cathepsin D & (Murphy et al. 2014) & $\mathrm{Cg} C \mathrm{x}$ & $\uparrow$ levels \\
\hline
\end{tabular}




\begin{tabular}{|c|c|c|c|}
\hline Cathepsin D & (Chu et al. 2009) & $\mathrm{SNc}$ & $\downarrow$ levels in neurons \\
\hline cathepsin D & (Mantle et al. 1995) & $\mathrm{Fr} C \mathrm{x}$ & $=$ levels \\
\hline cathepsin $\mathrm{H}$ & (Mantle et al. 1995) & $\mathrm{Fr} C x$ & $=$ levels \\
\hline cathepsin L & (Mantle et al. 1995) & $\mathrm{Fr} C x$ & $=$ levels \\
\hline Dipeptidyl aminopeptidase I & (Mantle et al. 1996) & Fr Cx & $=$ activity \\
\hline Dipeptidyl aminopeptidase II & (Mantle et al. 1996) & Fr Cx & $\downarrow$ activity \\
\hline Glucocerebrosidase & (Murphy et al. 2014) & $\mathrm{Cg} C \mathrm{x}$ & $\downarrow$ levels \\
\hline Glucocerebrosidase & (Gegg et al. 2012) & $\mathrm{Crb}$ & $\begin{array}{l}\downarrow \text { levels and } \\
\text { activity }\end{array}$ \\
\hline Glucocerebrosidase & (Gegg et al. 2012) & SN & $\begin{array}{l}\downarrow \text { levels and } \\
\text { activity }\end{array}$ \\
\hline Glucocerebrosidase & (Gegg et al. 2012) & $\mathrm{Ag}, \mathrm{Fr} \mathrm{Cx}, \mathrm{Pu}$ & $=$ levels \\
\hline Hsc70 & $\begin{array}{l}\text { (Alvarez-Erviti et al. } \\
\text { 2010),(Mandel } \text { et al. 2009) }\end{array}$ & $\mathrm{Ag}, \mathrm{SN}$ & $\downarrow$ levels \\
\hline HSP73 & (Chu et al. 2009) & SN & $\downarrow$ levels in neurons \\
\hline LAMP1 & (Dehay et al. 2010) & SN & $\downarrow$ levels \\
\hline LAMP1 & (Chu et al. 2009) & SN & $\downarrow$ levels in neurons \\
\hline LAMP2 & $\begin{array}{l}\text { (Alvarez-Erviti et al. } \\
\text { 2010),(Murphy et al. 2014) }\end{array}$ & $\mathrm{Ag}, \mathrm{Cg} \mathrm{Cx}, \mathrm{SN}$ & $\downarrow$ levels \\
\hline LC3II & (Dehay et al. 2010) & SN & $\uparrow$ levels \\
\hline LIMP-2 & (Rothaug et al. 2014) & SN & $\uparrow$ levels \\
\hline LMX1B & (Laguna et al. 2015) & SN & $\begin{array}{l}\downarrow \text { levels in TH } \\
\text { neurons }\end{array}$ \\
\hline MEF2D & (She et al. 2011) & Str & $\uparrow$ levels \\
\hline P-type ATPase (ATP13A2) & (Dehay et al. 2012) & SN & $\downarrow$ levels \\
\hline P-type ATPase (ATP13A2) & (Ramonet et al. 2012) & $\mathrm{Cx}, \mathrm{Str}$ & $\uparrow$ levels \\
\hline TFEB & (Decressac et al. 2013) & SN & $\begin{array}{l}\downarrow \text { nuclear levels in } \\
\text { TH neurons }\end{array}$ \\
\hline ULK1 (UNC-51-like kinase 1) & (Miki et al. 2015) & $\mathrm{SN}$ & $=$ levels \\
\hline ULK2 (UNC-51-like kinase 2) & (Miki et al. 2015) & SN & $=$ levels \\
\hline VPS34 & (Miki et al. 2015) & SN & $=$ levels \\
\hline
\end{tabular}


Table 7. Changes in apoptosis-related proteins observed in the human parkinsonian brain. Legend: see Table 1.

\begin{tabular}{|c|c|c|c|}
\hline Protein & Ref & Structure & Effect \\
\hline \multicolumn{4}{|l|}{ Apoptosis } \\
\hline AIMP2 & (Lee et al. 2013) & $\mathrm{SN}$ & $\uparrow$ levels \\
\hline Apaf-1 & (Kawamoto et al. 2014) & $\mathrm{SN}$ & $\uparrow$ levels in TH neurons \\
\hline Apaf-1 & (Kawamoto et al. 2014) & $\mathrm{LC}$ & $\uparrow$ levels \\
\hline Bax & (Tatton 2000),(Hartmann et al. 2001a) & $\mathrm{SN}$ & $\uparrow$ levels in TH neurons \\
\hline $\mathrm{Bcl}-2$ & (Letters et al. 1996),(Marshall et al. 1997) & $\mathrm{Ca}, \mathrm{GP}, \mathrm{Pu}, \mathrm{SN}$ & $\uparrow$ levels \\
\hline Bcl-2 & (Letters et al. 1996),(Marshall et al. 1997) & $\mathrm{Cb} C x, \mathrm{Cx}$ & $=$ levels \\
\hline $\mathrm{Bid} / \mathrm{tBid}$ & (Jiang et al. 2012) & $\mathrm{Tp} C \mathrm{x}$ & $\begin{array}{l}\uparrow \text { total and } \\
\text { mitochondrial levels }\end{array}$ \\
\hline Caspase-1 & (Mogi et al. 2000) & $\mathrm{SN}$ & $\uparrow$ activity \\
\hline Caspase-1 & (Mogi et al. 2000) & $\mathrm{Ca}, \mathrm{Cb}, \mathrm{Fr} \mathrm{Cx}, \mathrm{Pu}$ & = activity \\
\hline Caspase-3 & (Hartmann et al. 2000) & $\mathrm{SN}$ & $\begin{array}{l}\downarrow \text { nb of expressing TH } \\
\text { neurons }\end{array}$ \\
\hline Caspase-3 & (Jiang et al. 2012) & $\mathrm{Tp} \mathrm{Cx}$ & $\begin{array}{l}\uparrow \text { total and } \\
\text { mitochondrial levels }\end{array}$ \\
\hline Caspase-3 & (Tatton 2000),(Mogi et al. 2000) & $\mathrm{SN}$ & $\begin{array}{l}\uparrow \text { levels in TH neurons } \\
\text { and activity }\end{array}$ \\
\hline Caspase-3 & (Mogi et al. 2000) & $\mathrm{Ca}, \mathrm{Cb}, \mathrm{Fr} \mathrm{Cx}, \mathrm{Pu}$ & = activity \\
\hline $\begin{array}{l}\text { Caspase-3 } \\
\text { (cleaved) }\end{array}$ & (Jiang et al. 2012) & $\mathrm{Tp} C \mathrm{x}$ & $\begin{array}{l}\uparrow \text { total and } \\
\text { mitochondrial levels }\end{array}$ \\
\hline $\begin{array}{l}\text { Caspase-3 } \\
\text { (cleaved) }\end{array}$ & (Tatton 2000) & $\mathrm{SN}$ & $\uparrow$ levels in TH neurons \\
\hline $\begin{array}{l}\text { Caspase-8 } \\
\text { (activated) }\end{array}$ & (Viswanath et al. 2001) & $\mathrm{SN}$ & $\uparrow$ levels in TH neurons \\
\hline $\begin{array}{l}\text { Caspase-8 } \\
\text { (activated) }\end{array}$ & (Hartmann et al. 2001b) & SN & $\begin{array}{l}\uparrow \mathrm{nb} \text { of } \mathrm{TH} \text { expressing } \\
\text { neurons }\end{array}$ \\
\hline Caspase-9 & (Kawamoto et al. 2014) & $\mathrm{SN}$ & $\uparrow$ levels in TH neurons \\
\hline Caspase-9 & (Kawamoto et al. 2014) & $\mathrm{LC}$ & $\uparrow$ levels \\
\hline $\begin{array}{l}\text { Caspase-9 } \\
\text { (activated) }\end{array}$ & (Viswanath et al. 2001) & $\mathrm{SN}$ & $\uparrow$ levels in TH neurons \\
\hline $\begin{array}{l}\text { Caspase-9 } \\
\text { (cleaved) }\end{array}$ & (Kawamoto et al. 2014) & $\mathrm{SN}$ & $\uparrow$ levels in TH neurons \\
\hline $\begin{array}{l}\text { Caspase-9 } \\
\text { (cleaved) }\end{array}$ & (Kawamoto et al. 2014) & $\mathrm{LC}$ & $\uparrow$ levels \\
\hline Cytochrome c & (Kawamoto et al. 2014) & $\mathrm{SN}$ & $\uparrow$ levels in TH neurons \\
\hline Cytochrome c & (Kawamoto et al. 2014) & $\mathrm{LC}$ & $\uparrow$ levels \\
\hline Cytochrome c & (Jiang et al. 2012) & $\mathrm{Tp} C \mathrm{x}$ & $\begin{array}{l}\uparrow \text { total and } \downarrow \\
\text { mitochondrial levels }\end{array}$ \\
\hline Endonuclease G & (Büttner et al. 2013) & $\mathrm{SN}$ & $\begin{array}{l}\uparrow \text { nuclear localization } \\
\text { in } \mathrm{TH} \text { neurons }\end{array}$ \\
\hline FADD & (Hartmann et al. 2002) & SN & $\begin{array}{l}\downarrow \text { nb of expressing } \\
\text { neurons }\end{array}$ \\
\hline Fas & (Ferrer et al. 2000) & $\mathrm{SN}$ & $\downarrow$ levels \\
\hline Fas (soluble) & (Mogi et al. 1996a) & $\mathrm{Ca}, \mathrm{Pu}$ & $\uparrow$ levels \\
\hline Fas (soluble) & (Mogi et al. 1996a) & $\mathrm{CbCx}$ & $=$ levels \\
\hline $\begin{array}{l}\text { Fas-associated } \\
\text { factor } 1\end{array}$ & (Betarbet et al. 2008) & Fr Cx & $\uparrow$ levels \\
\hline FasL & (Ferrer et al. 2000) & $\mathrm{SN}$ & $\downarrow$ levels in TH neurons \\
\hline
\end{tabular}


FasL

p53

p53

p53

(phosphorylated (Camins et al. 2010)

at S15)

PAR polymer

Par-4

TNFR1 (p55)

TNFR1 (p55)

TRADD
(Ferrer et al. 2000)

(Sunico et al. 2013),(Mogi et al. 2007)

(Mogi et al. 2007)

(Lee et al. 2013)

(Moos and Jensen 2004)

(Jiang et al. 2012),(Mogi et al. 2000)

(Mogi et al. 2000)

(Jiang et al. 2012)
SN

$\mathrm{Ca}, \mathrm{Tp} \mathrm{Cx}$

$\mathrm{Cb}, \mathrm{Fr} \mathrm{Cx}, \mathrm{Pu}, \mathrm{SN}=$ levels

Cg Gy $\quad \uparrow$ levels

SN $\quad \uparrow$ levels

SN = levels

SN, Tp Cx $\quad \uparrow$ levels

$\mathrm{Ca}, \mathrm{Cb}, \mathrm{Fr} \mathrm{Cx}, \mathrm{Pu}=$ levels

Tp Cx $\quad \uparrow$ levels

\begin{tabular}{|c|c|c|c|c|}
\hline \multicolumn{5}{|l|}{ Cell cycle re-entry } \\
\hline Cdk5 & \multicolumn{2}{|c|}{ (Alvira et al. 2008) } & $\mathrm{Cg} \mathrm{Cx}$ & $\uparrow$ levels \\
\hline Cdk5 & \multicolumn{2}{|c|}{ (Rubio de la Torre et al. 2009) } & $\mathrm{Ca}, \mathrm{Cb}, \mathrm{Cx}$ & $=$ levels \\
\hline Cyclin D1 & \multicolumn{2}{|c|}{ (Camins et al. 2010) } & $\mathrm{Cg} C x$ & $\uparrow$ levels \\
\hline E2F-1 & \multicolumn{2}{|c|}{ (Alvira et al. 2008) } & $\mathrm{Cg} \mathrm{Cx}$ & $\uparrow$ levels \\
\hline E2F-1 & \multicolumn{2}{|c|}{ (Höglinger et al. 2004) } & $\mathrm{SN}$ & $\uparrow$ levels in TH neurons \\
\hline p25 & \multicolumn{2}{|c|}{$\begin{array}{l}\text { (Rubio de la Torre et al. 2009),(Alvira et al. } \\
\text { 2008) }\end{array}$} & $\mathrm{Ca}, \mathrm{Cg} \mathrm{Cx}$ & $\uparrow$ levels \\
\hline p25 & \multicolumn{2}{|c|}{ (Rubio de la Torre et al. 2009) } & $\mathrm{Cb}, \mathrm{Cx}$ & $=$ levels \\
\hline p35 & \multicolumn{2}{|c|}{ (Rubio de la Torre et al. 2009) } & $\mathrm{Ca}, \mathrm{Cb}, \mathrm{Cx}$ & $=$ levels \\
\hline PCNA & \multicolumn{2}{|c|}{ (Höglinger et al. 2004) } & $\mathrm{SN}$ & $\uparrow$ levels in TH neurons \\
\hline $\mathrm{pRb}$ & \multicolumn{2}{|c|}{ (Jordan-Sciutto et al. 2003) } & Fr Cx, Hp, SN & $\uparrow$ levels \\
\hline $\begin{array}{l}\mathrm{pRb} \\
\text { (phosphorylated) }\end{array}$ & \multicolumn{2}{|c|}{ (Jordan-Sciutto et al. 2003) } & Fr Cx, Hp, SN & $\uparrow$ nuclear levels \\
\hline \multicolumn{5}{|c|}{ Endoplasmic reticulum stress } \\
\hline $\begin{array}{l}\text { EIF2 } \alpha \\
\text { (phosphorylated } \\
\text { at S51) }\end{array}$ & \multicolumn{2}{|c|}{ (Hoozemans et al. 2007) } & $\mathrm{SN}$ & $\begin{array}{l}\uparrow \mathrm{nb} \text { of expressing } \mathrm{TH} \\
\text { neurons }\end{array}$ \\
\hline HERP & \multicolumn{2}{|c|}{ (Slodzinski et al. 2009) } & $\mathrm{SN}$ & $\uparrow$ levels \\
\hline IRE1 $\alpha$ & \multicolumn{2}{|c|}{ (Hoozemans et al. 2012) } & $\mathrm{SN}$ & $\begin{array}{l}\uparrow \mathrm{nb} \text { of expressing } \mathrm{TH} \\
\text { neurons }\end{array}$ \\
\hline $\begin{array}{l}\text { PERK } \\
\text { (phosphorylated } \\
\text { at Thr981) }\end{array}$ & \multicolumn{2}{|c|}{ (Hoozemans et al. 2007) } & $\mathrm{SN}$ & $\begin{array}{l}\uparrow \mathrm{nb} \text { of expressing } \mathrm{TH} \\
\text { neurons }\end{array}$ \\
\hline $\begin{array}{l}\text { PKR } \\
\text { (phosphorylated } \\
\text { at Thr446) }\end{array}$ & \multicolumn{2}{|c|}{ (Bando et al. 2005) } & $\mathrm{Hp}$ & $\uparrow$ nuclear levels \\
\hline \multicolumn{5}{|c|}{ Transcription factors and transduction pathways } \\
\hline \multicolumn{3}{|c|}{$\begin{array}{l}\text { 14-3-3 (phosphorylated at } \quad \text { (Slone et al. 2015) } \\
\text { S58) }\end{array}$} & Tp Cx & $\downarrow$ membrane levels \\
\hline \multicolumn{2}{|l|}{ 14-3-3 (total pan) } & (Slone et al. 2015) & $\mathrm{Tp} C \mathrm{x}$ & $=$ levels \\
\hline \multicolumn{2}{|c|}{$\begin{array}{l}14-3-3 \Theta \text { (phosphorylated at } \\
\text { S232) }\end{array}$} & (Slone et al. 2015) & $\mathrm{Tp} C \mathrm{x}$ & $\uparrow$ cytoplasmic levels \\
\hline \multicolumn{2}{|l|}{$14-3-3 \sigma$} & (Reynolds et al. 2008) & $\mathrm{SN}$ & $\uparrow$ levels \\
\hline \multicolumn{2}{|c|}{ Akt (phosphorylated at S473) } & (Timmons et al. 2009) & $\mathrm{Mb}$ & $\downarrow$ levels \\
\hline \multicolumn{2}{|c|}{ Akt (phosphorylated at S473) } & (Malagelada et al. 2008) & $\mathrm{SN}$ & $\downarrow$ levels in TH neurons \\
\hline
\end{tabular}




\begin{tabular}{|c|c|c|c|}
\hline Akt (phosphorylated at T308) & (Malagelada et al. 2008) & SN & $\downarrow$ levels in TH neurons \\
\hline Akt (total) & (Timmons et al. 2009) & $\mathrm{Mb}$ & $\downarrow$ levels \\
\hline ASK1 (phosphorylated) & (Hu et al. 2011) & SN & $\begin{array}{l}\uparrow \mathrm{nb} \text { of expressing } \mathrm{TH} \\
\text { neurons }\end{array}$ \\
\hline c-jun & (Hunot et al. 2004) & $\mathrm{SN}$ & $\uparrow$ levels in TH neurons \\
\hline c-Myc & (Ferrer and Blanco 2000) & $\mathrm{SN}$ & $=$ levels in $\mathrm{TH}$ neurons \\
\hline c-Myc & (Ferrer and Blanco 2000) & SN & $\begin{array}{l}\uparrow \mathrm{nb} \text { of expressing } \\
\text { astrocytes }\end{array}$ \\
\hline CREB (phosphorylated) & (Kurup et al. 2015) & Str & $\downarrow$ levels \\
\hline $\begin{array}{l}\text { CREB } \\
\text { (phosphorylated)/CREB }\end{array}$ & (Price et al. 2010) & $\mathrm{Fr} C \mathrm{x}$ & $\begin{array}{l}\uparrow \text { nuclear and } \downarrow \\
\text { cytoplasmic levels }\end{array}$ \\
\hline Elk (phosphorylated)/Elk & (Price et al. 2010) & $\mathrm{Fr} C \mathrm{x}$ & $=$ ratio \\
\hline ERK (phosphorylated)/ERK & (Price et al. 2010) & $\mathrm{Fr} C \mathrm{x}$ & $\uparrow$ ratio \\
\hline ERK1/2 (phosphorylated) & (Kurup et al. 2015) & Str & $\downarrow$ levels \\
\hline $\begin{array}{l}\text { GSK3 } \beta \text { (phosphorylated at } \\
\text { Y216) }\end{array}$ & (Wills et al. 2010) & Str & $\uparrow$ levels \\
\hline $\begin{array}{l}\text { GSK3 } \beta \text { (phosphorylated at } \\
\text { Y216) }\end{array}$ & (Wills et al. 2010) & $\mathrm{Fr} C \mathrm{x}$ & $=$ levels \\
\hline Itch & (Pranski et al. 2013) & $\mathrm{Cx}, \mathrm{SN}$ & $=$ levels \\
\hline JNK (phosphorylated) & (Hu et al. 2011) & SN & $\begin{array}{l}\uparrow \mathrm{nb} \text { of expressing } \mathrm{TH} \\
\text { neurons }\end{array}$ \\
\hline MEF2D & (Gao et al. 2014) & Str & $\downarrow$ mitochondrial levels \\
\hline MEF2D & (Chu et al. 2011) & SN & $\downarrow$ levels \\
\hline MEF2D & (Chu et al. 2011) & SN & $\downarrow$ levels in TH neurons \\
\hline NFATc4 & (Caraveo et al. 2014) & Fr Cx, Hp, SN & $\uparrow$ nuclear levels \\
\hline NF-кB (nuclear) & $\begin{array}{l}\text { (Soós et al. 2004)'(Hunot et al. } \\
\text { 1997) }\end{array}$ & SN & $\uparrow$ levels in TH neurons \\
\hline NF-кB (p50), cytosol & (Reynolds et al. 2008) & SN & $\begin{array}{l}\uparrow \text { cytosolic and nuclear } \\
\text { levels }\end{array}$ \\
\hline NF-kB (p65) & $\begin{array}{l}\text { (Reynolds et al. 2008) (Ghosh et } \\
\text { al. 2009) }\end{array}$ & $\mathrm{Mb}$ & $\begin{array}{l}\uparrow \text { total, cytosolic and } \\
\text { nuclear levels }\end{array}$ \\
\hline $\begin{array}{l}\text { NF- } \kappa B \text { (phosphorylated at } \\
\text { S536) }\end{array}$ & (Reynolds et al. 2008) & SN & $\uparrow$ levels \\
\hline NF-kB (total) & (Mogi et al. 2007) & $\mathrm{Ca}, \mathrm{Pu}, \mathrm{SN}$ & $\uparrow$ levels \\
\hline n-myc & (Ferrer and Blanco 2000) & SN & $=$ levels in $\mathrm{TH}$ neurons \\
\hline $\mathrm{n}-\mathrm{myc}$ & (Ferrer and Blanco 2000) & SN & $\begin{array}{l}\uparrow \mathrm{nb} \text { of expressing } \\
\text { astrocytes }\end{array}$ \\
\hline Nurr1 & (Chu et al. 2006) & SN & $\downarrow$ levels in TH neurons \\
\hline Nurr1 & (Chu et al. 2006) & SN & $\begin{array}{l}\downarrow \mathrm{nb} \text { of expressing TH } \\
\text { neurons }\end{array}$ \\
\hline p38 (phosphorylated) & (Hu et al. 2011) & SN & $\begin{array}{l}\uparrow \mathrm{nb} \text { of expressing } \mathrm{TH} \\
\text { neurons }\end{array}$ \\
\hline p53 & $\begin{array}{l}\text { (Sunico et al. 2013)'(Mogi et al. } \\
\text { 2007) }\end{array}$ & $\mathrm{Ca}, \mathrm{Tp} \mathrm{Cx}$ & $\uparrow$ levels \\
\hline p53 & (Mogi et al. 2007) & $\mathrm{Cb}, \mathrm{Fr} \mathrm{Cx}, \mathrm{Pu}, \mathrm{SN}$ & $=$ levels \\
\hline p53 (phosphorylated at S15) & (Camins et al. 2010) & Cg Gy & $\uparrow$ levels \\
\hline PGC- $1 \alpha$ & $\begin{array}{l}\text { (Eschbach et al. 2015; Shin et al. } \\
\text { 2011) }\end{array}$ & SN, Str & $\downarrow$ levels \\
\hline PTEN (S-nytrosylated) & (Choi et al. 2014) & $\mathrm{Fr} C \mathrm{x}$ & $\downarrow$ ratio / total DJ-1 \\
\hline RNF11 & (Pranski et al. 2013) & $\mathrm{Cx}, \mathrm{SN}$ & $\downarrow$ levels \\
\hline RPT801 (REDD1) & (Malagelada et al. 2006) & $\mathrm{SN}$ & $\uparrow$ levels in TH neurons \\
\hline Tax1BP1 & (Pranski et al. 2013) & $\mathrm{Cx}, \mathrm{SN}$ & $=$ levels \\
\hline
\end{tabular}




\section{Summarizing Schematic}

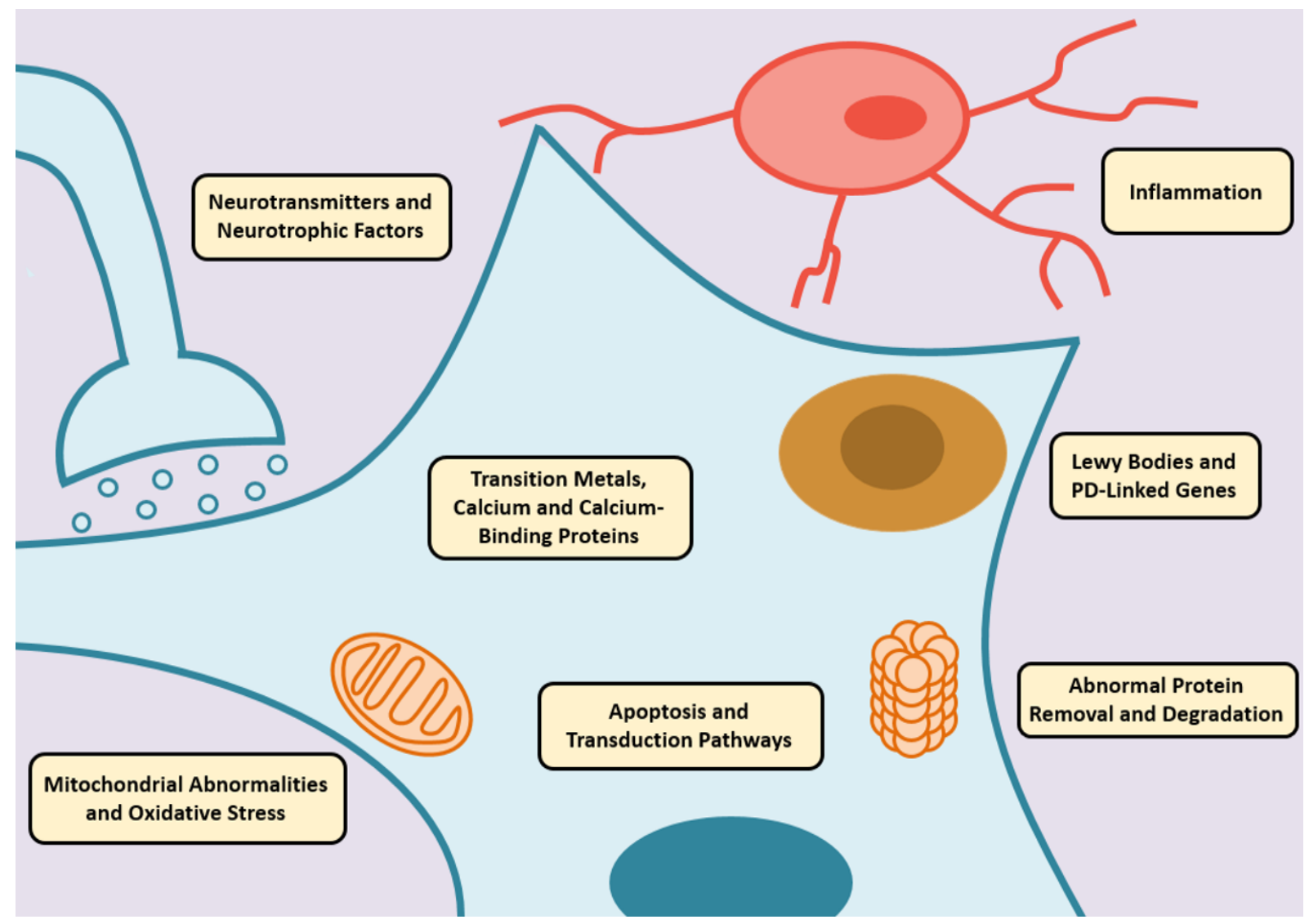

Parkinson's is accompanied by multiple changes in the brain that are responsible of the progression of the disease. We describe here the molecular alterations occurring in postmortem brains and classify them as: Neurotransmitters and neurotrophic factors; Lewy bodies and Parkinson's-linked genes; Transition metals, calcium and calcium-binding proteins; Inflammation; Mitochondrial abnormalities and oxidative stress; Abnormal protein removal and degradation; Apoptosis and transduction pathways. 